\title{
Correspondence, Camaraderie, and Community: \\ The Second World War for a Mother and Son
}

by

\author{
Emily Gann
}

A thesis submitted to the Faculty of Graduate and Postdoctoral Affairs in partial fulfillment of the requirements for the degree of

\section{Master of Arts}

in

History

\author{
Carleton University \\ Ottawa, Ontario
}

(C) 2012

Emily Gann 
Library and Archives

Canada

Published Heritage

Branch

395 Wellington Street

Ottawa ON K1A ON4

Canada
Bibliothèque et

Archives Canada

Direction du

Patrimoine de l'édition

395 , rue Wellington

Ottawa ON K1A ON4

Canada
Your file Votre référence

ISBN: 978-0-494-94300-7

Our file Notre référence

ISBN: $978-0-494-94300-7$
NOTICE:

The author has granted a nonexclusive license allowing Library and Archives Canada to reproduce, publish, archive, preserve, conserve, communicate to the public by telecommunication or on the Internet, loan, distrbute and sell theses worldwide, for commercial or noncommercial purposes, in microform, paper, electronic and/or any other formats.

The author retains copyright ownership and moral rights in this thesis. Neither the thesis nor substantial extracts from it may be printed or otherwise reproduced without the author's permission.
AVIS:

L'auteur a accordé une licence non exclusive permettant à la Bibliothèque et Archives Canada de reproduire, publier, archiver, sauvegarder, conserver, transmettre au public par télécommunication ou par l'Internet, prêter, distribuer et vendre des thèses partout dans le monde, à des fins commerciales ou autres, sur support microforme, papier, électronique et/ou autres formats.

L'auteur conserve la propriété du droit d'auteur et des droits moraux qui protege cette thèse. $\mathrm{Ni}$ la thèse ni des extraits substantiels de celle-ci ne doivent être imprimés ou autrement reproduits sans son autorisation.
In compliance with the Canadian Privacy Act some supporting forms may have been removed from this thesis.

While these forms may be included in the document page count, their removal does not represent any loss of content from the thesis.
Conformément à la loi canadienne sur la protection de la vie privée, quelques formulaires secondaires ont été enlevés de cette thèse.

Bien que ces formulaires aient inclus dans la pagination, il n'y aura aucun contenu manquant. 


\section{Abstract}

Erle Sinclair Miller enlisted in the Royal Canadian Air Force (RCAF) in 1940. While his initial attitude towards the conflict was one of personal invincibility and an eagerness for action, much of Miller's Second World War experience was spent in five prisoner of war camps, enduring physical as well as psychological hardship. The following thesis engages with the contents of the Miller Collection, a series of 297 letters, two prisoner of war journals, one flying log book and one scrapbook, in order to reveal the details of a young man's experiences of war and the critical relationship he retained with his mother in Canada. The key themes in this analysis, that of identity, community, and coping, are drawn out in each of the following three chapters, and offer an intimate appreciation of the impact that the Second World War had on families, sharper insight into the dynamics of the RCAF and prisoner of war experience, the intersection of communities of war, and the role of mothers on the home front. 


\section{Table of Contents}

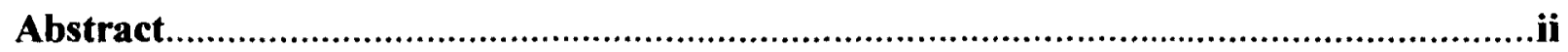

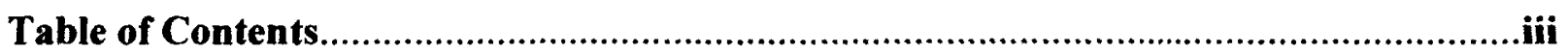

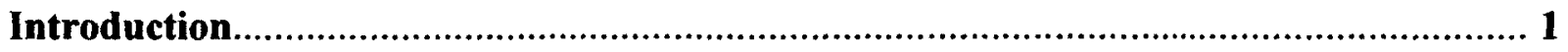

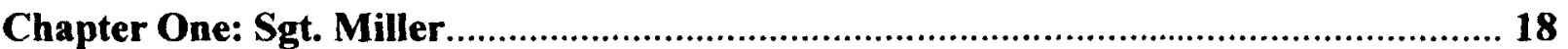

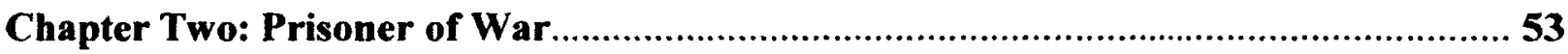

Chapter Three: Mother on the Home Front..................................................... 91

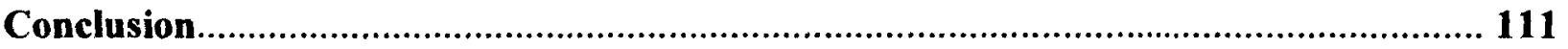

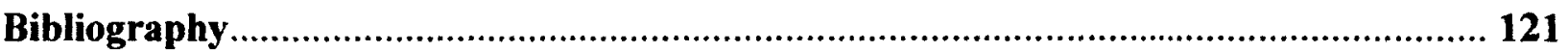




\section{Introduction}

As you know I was in the last world war and it was no fun at all.

[...] Of the seven of us that joined in Ottawa:

1st one killed. Red Mayville

2nd Harvey Lasselle - Killed on fighters

3rd Ray Bergois. - Killed [on] Bombers

4th Peter Reid. - Killed [on] Bombers

5th Smoky McLaughlin. - Killed [on] Bombers

6th Ray Villeneuve. - Killed [on] Bombers

7th Dusty Miller - Prisoner War - Still living.

Sailors, soldiers \& airmen getting wounded \& killed, not to mention civilians, men, women \& children receiving the same thing. [...]Believe me war is no fun!! And there is a very good chance you can get killed or lose an arm or leg or both.

In this letter written roughly 50 years after he was shot down returning from a bombing raid on Berlin, Germany, Erle Miller reflected on the very high cost of war and on the grim fact that he was the only man of the six with whom he had enlisted in 1940 to survive the war. The letter is part of the Miller Collection, a series of 297 letters, two prisoner of war journals, one Flying Log Book, and one scrapbook that capture and reflect the period of Miller's active service and imprisonment during the Second World War. ${ }^{2}$ Out of this grand total, 183 pieces of correspondence were sent from Miller to his mother during his four and a half years overseas, a period which saw him through 12 months of active service with the Royal Canadian Air Force

\footnotetext{
'Erle Miller, Brockville, Ontario, to Alex Wilson, St. Catharines, [no calendar day given], 1991. These letters and personal writings have been transcribed in this thesis exactly as they appear in the Miller Collection. The Commonwealth War Graves Commission's website confirms that these airmen died during the war: John Maville on 22 June 1941; Harvey Lacelle on 28 June 1942; Laurie Bourgeois on 12 June 1943; Stanleigh Reid on 1 June 1942; George McLaughlin on 18 November 1943 and Robert Villeneuve, on 20 November 1944.

${ }^{2}$ The collection contains 66 letters that Miller sent during his active service with the RCAF, and 117 pieces of correspondence that he sent from behind barbed wire as a POW. All of the letters Miller wrote home during the Second World War were intended for his mother and, through such communications, it can be inferred that she was the primary author of the correspondence he received from his family. The Miller Collection does not contain any correspondence between Miller and his father.
} 
(RCAF) and 45 months as a prisoner of war, from September 1941 to May $1945 .^{3}$ The

remaining 114 letters were received by his mother, Gladys Miller, from 12 September 1941 until

7 April 1944, and are connected to her son's captivity. The last piece in this part of the Miller Collection was received almost a year before Miller's liberation, and, given the short period of time between his transfer to and then his forced march in April 1945, it is highly likely that this was the last note his family received prior to a telegraph of 9 May 1945: "Arrived safe England See you soon."

Erle Sinclair Miller was born in Beaver Lake, Alberta, on 14 March 1920 to Gladys and Donald Miller. When he was three years old, Miller and his family moved to Castleford, Ontario, where Miller lived until his departure for war in June 1940. From 1926 until 1933 he attended Renfrew Public School and Renfrew Collegiate from 1933 to 1936, achieving a Grade 11 certificate. ${ }^{5}$ The following year, Miller was awarded a diploma from Drummond's Business College after two semesters of study, where he took courses in Bookkeeping, Typing, Shorthand and Filing, and then worked as a bookkeeper and clerk for two years at J.H. Russell's Drug Store in Renfrew. ${ }^{6}$ Miller left his employment at the local drug store for war, and while none of his letters tell us why he chose to enlist, his RCAF application form offers insight into his decision. This document contains a section entitled "Trades or Branches in which Applicant Prefer Enlistment or Appointment," and beneath this heading, Miller wrote "Pilot" as his first choice.

\footnotetext{
${ }^{3}$ Since September 2010, Miller's military records have been added to the Miller Collection. These records are his Application for Enlistment in the RCAF, Service Award Card, a Prisoner of War casualty report, a list of courses taken while in the RCAF, attestation papers, and an Airman's Record Sheet.

${ }^{4}$ Erle Miller to Gladys Miller, Telegraph, 9 May 1945.

5 Department of Veterans Affairs, "Erle Miller - Confidential, 19 September 1945", Library and Archives Canada, Ottawa, Ontario. As of November 2011, a copy of this document has been added to the Miller Collection. John Gann, Eulogy for Erle Sinclair Miller, Brockville, Ontario, April 1995.

${ }^{6}$ Ibid.

${ }^{7}$ Miller also wrote down "Office Position Admin." as his second choice. Miller did not provide a third choice for this section of his application. Royal Canadian Air Force, "Application for Enlistment or Appointment in the RCAF
} 
This entry suggests, quite simply, that Miller enlisted because of his desire to become a pilot in the RCAF.

The Miller Collection allows for the reconstruction of a young man's experiences of war and the critical relationship he retained with his mother in Canada. By examining this body of writing against the backdrop of the existing scholarship of war, this collection reveals themes of identity, community, and coping. These themes are drawn out in each of the following three chapters, and offer an intimate appreciation of the impact that the war had on families, sharper insight into the dynamics of the RCAF and prisoner of war experience, the intersection of communities of war, and the role of mothers on the home front. The chapters in this thesis parallel Miller's wartime experiences and are broken down as follows: Chapter One: "Sgt. Miller"; Chapter Two: "Prisoner of War"; and Chapter Three: "Mother on the Home Front". The Miller Collection is comprised of a series of personal letters, private journal writings and official documentation that taken together trace a mother and son's wartime experience from 25 August 1940 to 5 June 1945. Miriam Dobson has commented that, especially where letters between family members with a 'close emotional tie' are concerned, one can:

assume that ... they essentially tell 'the truth' about their lives. Following this logic their letters should therefore give us a window onto the private experiences and inner thoughts of the author. Letters are often praised for the 'human dimension' they bring to history, allowing the scholar to capture raw experiences and emotions of actors in the past. ${ }^{8}$

In her work on French soldiers' epistolary tradition during the First World War, Martha Hanna has argued that letter-writing allowed soldiers to sustain an intimacy with their families which

(Erle Sinclair Miller), 5 May 1939", Library and Archives Canada, Ottawa, Ontario. As of November 2011, a copy of this document has been added to the Miller Collection.

${ }^{8}$ Miriam Dobson and Benjamin Ziemann, eds., Reading Primary Sources: The Interpretation of Texts from 19th and 20th Century History (New York: Routledge, 2009), 62. 
was at least as important in shaping an individual's sense of self as their wartime environment. ${ }^{9}$ When working with such documents Dobson suggests keeping in mind the author's intended audience and to interpret such sources as a dialogue, as "the writer is always responding to previous interactions and earlier exchanges."10

In order to better place the contents of the Miller Collection within the existing field of archival material from Canadian airmen, 11 other collections of this nature, located at the Canadian War Museum, were consulted. ${ }^{11}$ This selection represents a variety of Second World War experiences, as the subjects served in various squadrons during different periods of the war, but manifest themes similar to those found in the Miller Collection, such as identity, comradeship, morale, emotional survival, and family ties. While these central topics are instrumental in establishing a general collective experience, they also help to identify the ways in which the Miller Collection is distinct, in both content and scope, in comparison to other unpublished collections.

A special feature of the Miller Collection is the way in which the letters capture the close relationship that Miller had with his mother. ${ }^{12}$ Miller was often willing to disclose personal and private matters with his mother, such as the state of his finances and his romantic interests. Such openness between parent and child is striking and is unmatched in the 11 other private collections examined which contain nothing, for example, on romantic relationships. The Miller Collection also presents the devoted effort that Gladys Miller made on the home front to provide

\footnotetext{
${ }^{9}$ Martha Hanna, "A Republic of Letters: The Epistolary Tradition in France during World War 1" American Historical Review 108, no. 5 (December 2003): 1341.

${ }^{10}$ Dobson, "Letters", 67.

11 These collections were selected because they represent Canadian airmen who served overseas during roughly the same time period as Miller. While the Canadian War Museum contains 18 collections from airmen of the Second World War, these 11 were specifically chosen because are from members of the RCAF and contained at least 10 letters.

${ }^{12}$ While Miller asks after his father, none of the letters in this collection are specifically addressed to him, nor does Miller mention any correspondence from his father. As a result, it is difficult to gauge Miller's relationship with his father.
} 
for her son throughout his incarceration in Germany. While a link to the home front is readily apparent in the other 11 collections, as the majority of the letters contained in those collections are intended for wives living in Canada, they do not provide the same in depth coverage of women's lives on the home front evident in the Miller Collection. The latter, however, affords a rich opportunity to explore and to reconstruct the various communities of support available to an Ottawa Valley mother of a Canadian airman during the Second World War.

The Miller Collection's 117 personal letters and two prisoner of war journals, which together cover Miller's four year as a prisoner of war, allow for an intimate account of Miller's incarceration. ${ }^{13}$ Prisoner of war journals, in particular, have largely not survived as they were often seized by prison guards, or discarded by Allied captives in preparation for the forced marches of the spring of 1945 . Without such documentation, the true deprivation from which Miller suffered, as well as his ability to endure and cope with such circumstances, would be unknowable. While the Miller Collection's first journal, which dates from 1 January 1942 until December of that year, offers a written account of the role that food and malnourishment had in dictating his experience in POW camp, such as "Have dose of dysentery and very weak \& hungry," it also draws attention to the small and seemingly insignificant luxuries, such as reprieve from work duties and access to libraries and sports equipment that captives could be allowed depending upon their rank and service. ${ }^{14}$ Similarly, Miller's second prisoner of war journal also illustrates the very different and trying camp conditions that he suffered from 1 August 1944 until 5 June 1945. This document contains an account of his forced march and

\footnotetext{
${ }^{13}$ The Guy Rainville Collection at the Military History Research Centre in the Canadian War Museum contains 43 letters which he sent to his wife from 31 January 1944 to 5 May 1945. Given the short period that he was a prisoner of war, the number of letters he sent from behind barbed wire is impressive, but these notes do not present variations in camp conditions. Guy Rainville Collection, "Prisoner of War Letters, January 1944 to May 1945", [5bA 1 192.6], Canadian War Museum, Ottawa, Ontario.

${ }^{14}$ Miller, POW Journal, v.1. 5, 19 March 1942.
} 
ensuing liberation. Consequently it helps to fill the large gap which exists in the letter collection between 7 April 1944 and the end of the war.

This study has also used the Ottawa Valley newspaper, the Renfrew Mercury, Miller's hometown newspaper, to provide a home front context. The Renfrew Mercury was established in 1871 and, as a weekly publication, was a comprehensive small town newspaper that circulated to a rural audience. As a source of information, newspapers not only reveal events, but, as Stephen Vella argues in his work on newspapers as sources, "often shaped the news and views of their readers by employing a particular framework for understanding events."15 As such, Vella suggests that newspapers allow for insight into "how societies or cultures came to understand themselves and the world around them." 16 Beginning on 7 September 1939, the Renfrew Mercury blended news of Canada's war effort and the events of various military theatres, alongside local interests, such as coverage of Renfrew's yearly fair. The weekly Renfrew Mercury also included an op-ed section which allowed members of this rural-Ontario community to publicly express individual opinion and thought on the country's involvement in the Second World War. ${ }^{17}$ Miller's letters home indicate that he greatly enjoyed receiving this newspaper while overseas; on one occasion he wrote: "Received the Mercury from Aunt Mabel to-day dated Aug. the 7th so that was pretty good. Thought that was nice of Aunt Mabel."18 The Renfrew Mercury was also a conduit through which the Miller family shared news about their son when he was reported missing in action, and later, to suggest to the local community how they might help Miller behind barbed wire. By using the Renfrew Mercury, in conjunction with the Miller

\footnotetext{
${ }^{15}$ Stephen Vella, "Newspapers," in Reading Primary Sources: The Interpretation of Texts from 19th and 20th Century History, edited by Miriam Dobson and Benjamin Ziemann (New York: Routledge, 2009), 193.

${ }^{16}$ Ibid., 193.

${ }^{17}$ Ian Miller's work on Toronto and the Great War utilizes newspapers in a similar fashion and he places a large emphasis on this source as an outlet for public appreciation of events and the development of ideas. Ian Miller, Our Glory and Our Grief: Torontonians and the Great War (Toronto: University of Toronto Press, 2002), 36.

${ }^{18}$ Erle Miller to Gladys Miller, 7 August 1940.
} 
Collection, the thesis sheds greater light upon how this local community experienced the Second World War and, in turn, allow for a fuller appreciation of the Miller family's home front experience from 1939 to 1945.

The letters, journals, scrapbook and log book in the Miller Collection trace Miller's transition from civilian to airman to prisoner of war to liberated airman, and offer a first hand account of how he served, endured and coped through the Second World War. Miller's change in status from active serviceman to prisoner of war was a drastic transformation that not only impacted his appreciation for his role in the war, but also altered his mother's efforts on the Canadian home front. With this change in status came different lived experiences for both mother and son, realities which were informed by their interactions with informal communities who shared in these experiences, such as fellow servicemen behind barbed wire and mothers of prisoners. These relationships are central to appreciating the complexity of the Miller family's Second World War and, while many different definitions for the term 'community' exist, sociologist Robert A. Nisbet's definition best explains the communities of war presented in the Miller Collection. Nisbet defines 'community' as:

"founded on [humankind] conceived in [its] wholeness rather than in one or another of the roles, taken separately, that [men and women] may hold in a social order. It draws its psychological strength from levels of motivation deeper than those of mere volition or interest, and it achieves its fulfillment in a submergence of individual will that is not possible in unions of mere convenience or rational assent. Community is a fusion of feeling and thought, of tradition and commitment, of expression by, locality, religion, nation, race, occupation or crusade. Its archetype is the family, and in almost every type of genuine community the nomenclature of family is prominent. Fundamental to the strength of the bond of community is the real or imagined antithesis formed of the same social setting by the noncommunal relations of competition or conflict, utility or contractual assent. These, by their relative impersonality and anonymity, highlight the close personal ties of community. ${ }^{19}$

\footnotetext{
${ }^{19}$ Robert A. Nisbet, Sociology as an Art Form (New York: Oxford University Press, 1967), 47-48.
} 
While this definition highlights the centrality of the family bond in creating a sense of community between individuals, it also mentions locality and commitment, two elements which were instrumental in informing Miller and Gladys's networks throughout the war.

During his active service and incarceration, Miller's communities were constructed within the different spaces he shared with fellow servicemen. Throughout his active service, for example, Miller's identity was developed in the relationships he shared with those with whom he served and socialized. As a prisoner of war, it was a social understanding that was established through the confines of a prisoner of war camp as these places determined who Miller interacted with, as well as what made up his daily routine. In his work on social theory, Gerard Delanty suggests that individuals are bound to one another by sharing a geographic place, and taking part in the activities that occur within this common space. ${ }^{20}$ Aside from his own personal resolve and the comforts afforded to him by members of his home front, Miller was able to cope with his incarceration through the support that he found within this POW community. In his work on life behind barbed wire, Adrian Gilbert attests that POWs shared in the "value of comradeship. For many this was the cord that bound them together in their darkest hour. To have a few close friends who would look out for each other could, in the worst circumstances, be the difference between life and death."21

Paralleling Miller's bonds behind barbed wire, his mother was able to provide comfort for her son through a home front system of support that was established to facilitate the provision of goods for POWs. The help and comfort that Gladys was offered through these home front communities is in keeping with Nisbet's definition of the term, as these networks were a result of the commitment of its members to the 'defence' of POWs overseas. As indicated in the 112

${ }^{20}$ Gerard Delanty, Community (London: Routledge, 2003), 55.

${ }^{21}$ Adrian Gilbert, POW: Allied Prisoners in Europe, 1939-1945 (Great Britain: John Murray, 2006), 323. 
letters from this period, Gladys facilitated for her son's well being through the relationships she developed with individuals, organizations, charities and agencies that were formed to assist families of POWs. ${ }^{22}$

The Miller Collection, which traces the experiences of an individual member of the RCAF serving in RAF squadrons, represents a history that has been largely overlooked in the collective narrative of Canadian air force historiography which focus, instead, on the policies and history of the RCAF. British official historians Noble Frankland and Sir Charles Webster published the seminal work, The Strategic Air Offensive Against Germany, 1939-1945, in 1961, several decades before Canadian historians were able to complete a comparable work on the history of the RCAF; in 1994, Canadian historians published the third volume of the RCAF official history: Crucible of War, 1939-1945, which filled this void. ${ }^{23}$ In his book on the historiography of Canada and the two world wars, Tim Cook suggests that it was an issue of policy and people that delayed the writing of this history: "During the war it had been the policy of Canadianization - the various attempts and failures of the government and military to draw Canadian flyers together into national squadrons and commands - that was so difficult to write about with contemporaries still alive."24

The 1990s and early 2000s reflected a period of great interest in the history of the RCAF and, as a result, works such as Spencer Dunmore and William Carter's Reap the Whirlwind (1991), Dunmore's Above and Beyond (1996), and David Bashow's No Prouder Place (2006)

\footnotetext{
${ }^{22}$ For an introduction to the different approaches and theories of community, see Benedict Anderson, Imagined Communities: Reflections on the Origin and Spread of Nationalism (London: Verso, 1991), and Tony Blackshaw, Key Concepts in Community Studies (London: SAGE Publications Ltd., 2010).

${ }^{23}$ Brereton Greenhous, Stephen Harris and William Johnston, The Crucible of War, 1939-1945: The Official History of the Royal Canadian Air Force, Volume III (Toronto: University of Toronto Press, 1994).

${ }^{24}$ Tim Cook, Clio's Warriors: Canadian Historians and the Writing of the World Wars (Vancouver: UBC Press, 2006), 292.
} 
were published. ${ }^{25}$ While these histories detail the larger war effort and wartime policy, technology and tactics, they do not place the experiences of individual Canadians within these larger discussions, nor do they examine the experiences of individual Canadian airmen serving within the RAF.

Squadron histories, such Ron Wylie's history of 400 Squadron, provide a more detailed appreciation of the daily routines of airmen serving in both the RCAF and RAF. ${ }^{26}$ Wylie's study spans 50 years of this squadron's operational history, and as such, provides a useful contextual information for Miller's wartime active service, but it does not discuss the experiences of airmen, nor does it grapple with the general themes of the following thesis, such as nationalism and identity. In this way, Wylie's work allows for an understanding of the squadron's role in the war, but it leaves room for others to explore how airmen felt and interpreted this duty. Alongside these official squadron histories, Robert Kirby's Avro Manchester: The Legend Behind the Lancaster offers a very focused study of 207 Squadron and the Avro Manchester during the Second World War. His book contains many first hand accounts (through extensive oral interviews) of the war, and, most notably, a thorough description of Miller's last operation and ensuing crash landing on 7 September $1941 .{ }^{27}$ During the course of his research, Kirby contacted Miller but he had no interest in discussing his last sortie nor his wartime experiences; an unfortunate dead end for Kirby. By incorporating the oral histories of the servicemen of 207

\footnotetext{
${ }^{25}$ Spencer Dunmore and William Carter, Reap the Whirlwind: The Untold Story of 6 Group, Canada's Bomber Force of World War II (Toronto: McClelland \& Stewart Inc., 1991), Spencer Dunmore, Above and Beyond: The Canadians' War in the Air, 1939-1945 (Toronto: McClelland and Stewart Inc., 1996) and David Bashow, No Prouder Place: Canadians and the Bomber Command Experience, 1939 to 1945 (St. Catharines: Vanwell Publishing Limited, 2006).

${ }^{26}$ Ron Wylie, 400 (City of Toronto) Squadron History: 1932 to 1966 (Toronto: 400 Squadron, 1996). During his year of active service overseas, Miller was stationed with: 112 (AC) Squadron High Post Aerodrome, 400 Squadron, 225 Squadron, and 207 Squadron.

${ }^{27}$ Robert Kirby, Avro Manchester: The Legend Behind the Lancaster (Leicester: Midland Publishing Limited, 1995). For examples of squadron histories published during this period, see: Ron Wylie, 400 (City of Toronto) Squadron History: 1932 to 1966 (Toronto: 400 Squadron, 1996), and Nora Bottomley, 424 Squadron History (Stittsville: Hangar Bookshelf, 1985).
} 
Squadron, Kirby's work provides insight into the experiences of airmen, who, like Miller, flew sorties in Manchesters and, more closely related to the Miller Collection, were part of his last operation on 7 September 1941.

Alongside such works, the publication of personal memoirs of airmen has also increased within the last two decades, offering first hand insight into the military and social experiences of airmen. ${ }^{28}$ These works add nuance to the overall RCAF narrative, as these studies shy away from the larger discussions of RCAF/RAF policy, scope, and implementation, and focus, instead, on individual experiences within the air force. While these works offer an increased awareness of the different types of experiences of airmen in the RCAF and RAF, they do not provide any strong analytical framework for engaging with such material. Martin Francis's The Flyer: British Culture and the Royal Air Force, 1939-1945, however, is a welcome study that situates the flyer in British popular culture during the Second World War. Francis attempts to convey the character, feelings, and motivations of those who flew, and his work is "much more closely aligned with the preoccupations of those engaged in the academic fields of cultural history and gender history." ${ }^{29}$ Francis's work provides a cultural analysis of the lives of RAF airmen, by illuminating "issues of gender, social class, racial identities, emotional life and the creation of a national myth in the twentieth century." ${ }^{30}$ His second chapter engages with the ways that flyers bonded with each other and emphasizes a number of the themes found in the Miller Collection. Francis's examination of shared rituals and leisure activities helped to inform Chapter One: "Sgt. Miller," in which I draw out discussions of camaraderie within the RAF and RCAF.

\footnotetext{
${ }^{28}$ Examples of such memoirs are: Tony Benn, Years of Hope: Diaries, Letters and Papers, 1940-1962 (London: Hutchinson, 1994), Eric Brown, Wings on My Sleeve (London: Weidenfeld \& Nicolson, 2006), and Geoffrey Page, Shot Down in Flames: A World War Two Fighter Pilot's Remarkable Tale of Survival (London: Grub Street, 1999). ${ }^{29}$ Martin Francis, The Flyer: British Culture and the Royal Air Force, 1939-1945 (Oxford: Oxford University Press, 2008), 4.

${ }^{30}$ Francis, The Flyer, 3.
} 
The history of Allied prisoners during the Second World War in Germany is one that has traditionally been over-simplified, focusing, almost exclusively, on the role of escape in the lives of captives behind barbed wire. This narrative is central to the works of A.J Barker in Behind Barbed Wire (1974), and Pat Reid's Escape from Colditz (1973), whose volumes are thorough in their descriptions of escape plans but offer little discussion of how servicemen endured, coped, and survived confinement. ${ }^{31}$ This focus may be attributed to the ongoing public interest in the deprivation experienced within camps and the heroism it took to attempt to escape from such conditions. Recent scholarship, however, encourages a broader appreciation of prisoner life and moves beyond the narrow focus of uniform camp experiences.

The 2006 works of both S.P. MacKenzie and Adrian Gilbert have made significant contributions to providing a more complete understanding to prisoner life within German POW camps. ${ }^{32}$ Both of these studies extend outside the focus on disillusion and escape, and this recent scholarship sheds new insight on the oppressive boredom of life behind the wire and how captives managed to deal with such monotony and stagnation. MacKenzie's The Colditz Myth: The Real Story of POW life in Nazi Germany (2006) moves beyond the traditional image of the 'escape-proof' castle of Oflag IV and, instead, uses the popular symbol of Colditz to offer a reevaluation of camp life across the Reich. The result is a dismantling of the 'myth' of POW life

\footnotetext{
${ }^{31}$ For an introduction to the topic of escape in Allied prisoner of war camps during the Second World War, see Aidan Crawly, Escape from Germany: The Methods of Escape Used by RAF Airmen During the Second World War (London: HMSO, 1985), Alan Burgess, The Longest Tunnel: The True Story of World War II's Great Escape (London: Bloomsbury Publishing, 1990), Ian Dear, Escape and Evasion: POW Breakouts in World War Two (London: Cassell, 2000), Jonathan Vance, A Gallant Company: The Men of the Great Escape (Pacifica, Cal.: Pacifica Press, 2001), and R.T. Bickers, Home Run: Great RAF Escapes of the Second World War (London: Leo Cooper, 1992).

${ }^{32}$ While these books are of particular note, the growing historiography surrounding life and routine behind barbed wire is also discussed by Charles Rollings, Prisoner of War: Voices from Behind the Wire in the Second World War (London: Random House, 2008), Daniel Dancocks, In Enemy Hands: Canadian Prisoners of War, 1939-1945 (Edmonton: Hurtig Publishers, 1983), David Rolf, Prisoners of the Reich: Germany's Captives, 1939-1945 (London: Leo Cooper, 1988), Philip Lagrandeur, We Flew, We Fell, We Lived: The Remarkable Reminiscences of Second World War Evaders and Prisoners of War (London: Grub Street, 2007), and Vasilis Vourkoutiotis, Prisoners of War and the German High Command: The British and American Experience (London: Palgrave Macmillan, 2003).
} 
as defined solely by brazen escape attempts. In its place, MacKenzie reconstructs the tale of dayto-day drudgery and the perpetual hunger that plagued inmates, while simultaneously offering first-hand accounts of the activities available to certain POWs, such as music, theatre, sports, and libraries. Within this deconstruction of daily living, MacKenzie argues that there was no typical POW experience as the characteristics of inmates, such as age, rank, social background, and the differences between the various German prisoner camps, were each important factors in determining ones experience of incarceration. Gilbert's work, POW: Allied Prisoners in Europe, 1939-1945 (2006), provides valuable insight into the ways that POWs could cope behind barbed wire. With a focus on the often overlooked activities available to Allied POWs, Gilbert argues that:

Despite the fundamentally negative nature of POW life, there were positive aspects that sprang from the prisoners' own determination to make the most of their otherwise poor lot. Escape and sabotage were obvious ways of fighting back against the enemy, but there were other, more oblique, means adopted by prisoners to maintain a sense of purpose and dignity. Imprisonment provided men with an opportunity to develop their artistic and intellectual potential. ${ }^{33}$

The Miller Collection reinforces the existing scholarship by offering insight into the variety of camp conditions Miller faced as he moved through five different camps from 12 September 1941 until 2 May 1945. The Miller Collection and the following analysis, then, shares in and reinforces the conclusions reached by both MacKenzie and Gilbert, namely, that there was no standard prisoner of war experience.

\footnotetext{
${ }^{33}$ Gilbert, POW, xii. While Gilbert's work provides a summary of these different activities, recent publications on camp libraries and sports behind barbed wire have allowed for a greater understanding of Miller's experiences as a POW. For insight into libraries and camps, see: David Shavit, "The Greatest Morale Factor next to the Red Army": Books and Libraries in American and British Prisoner of War Camps in Germany During World War II," Libraries and Culture 34, 2 (Spring 1999): 112-122; David Rolf, "The Education of British Prisoners of War in German Captivity, 1939-1945," History of Education 18 (1989): 257-265; for incarcerations and sports, see: John Dreiford, "Anything but Ordinary: POW Sports in a Barbed Wire World," Journal of Sports History (Fall 2007): 415-437.
} 
The third chapter of this thesis engages with discourse surrounding Canadian women and the Second World War. Scholarship in this field has previously centered on the role of women in uniform and in voluntary service at home and abroad, and has largely tended to ignore the role of mothers of active servicemen and POWs during the Second World War. Ruth Roach Pierson has been instrumental in the discourse surrouding women's participation in the workforce and the military from 1939 to 1945, in They're still Women after All: The Second World War and Canadian Womanhood, and argues that the persistence of discrimination through gender-based stereotypes after the war prevented any significant change in the "male-dominant sex/gender system of Canadian society." 34 She describes the volunteer activities of women, engaged in the home front effort, as fitting into this gendered pattern because these labours were unpaid, but does not extend her analysis to women, such as Gladys, whose efforts were strictly for their loved ones overseas and behind barbed wire. ${ }^{35}$ Nor does her work completely consider the importance of such activities, and the role they had in contributing to the larger Canadian effort, both at home and abroad. Despite the voluntary services of the Canadian Red Cross, which had an enormous influence on the lives of POWs from all Commonwealth countries and the United States, and utilized thousands of women volunteers to fulfill its objectives, there is not a single reference in Pierson's book to women's work within the organization. ${ }^{36}$ While Pierson has maintained a position of authority within this subject area, her work does not engage with the agency of mothers of airmen during the Second World War.

\footnotetext{
${ }^{34}$ Ruth Pierson, "They're Still Women After All": The Second World War and Canadian Womanhood (Toronto: McClelland and Stewart, 1986), 21.

${ }^{35}$ Pierson's work understands labour as a form of paid employment rather than the efforts of individuals and, as such, disregards tasks which were completed by women in an unpaid capacity.

${ }^{36}$ For an introduction to the role of Canadian relief agencies in supplying aid and assisting POWs overseas see Jonathan Vance, "Canadian Relief Agencies and Prisoners of War, 1939-1945," Journal of Canadian Studies 31 (1996): 133-147; Vasilis Vourkoutiotis, "What the Angels Saw: Red Cross and Protecting Power Visits to AngloAmerican POWs, 1939-45," Journal of Contemporary History 40 (2005): 690-708; and John Hutchinson, Champions of Charity: War and the Rise of the Red Cross (Colorado: Westview Press, Inc., 1996).
} 
Jeffrey Keshen's 2004 publication Saints, Sinners, and Soldiers: Canada's Second World War acknowledges Pierson's influence within this growing body of historiography, and explores those areas which were left out of her seminal work, particularly women in voluntary organizations and the changing nature of women in the domestic sphere. While Keshen briefly discusses the opportunities for women in the Women's Voluntary Service Division, he confesses that "because of the prestige of these Women's Voluntary Service Offices, as well as their appeal to patriotism, WVSOs invariably attracted women of stature to run their affairs $[\ldots] .{ }^{, 37}$ As such, very little is said about working and middle-class women's involvement in such organizations, save that their voluntary contributions to the war effort were "heartening and often beyond expectation." 38

Pearson and Keshen's respective works have made a considerable contribution to this growing field, but these studies, and the associated body of literature, do not engage with the important role that mothers played in the lives of their sons during the Second World War. ${ }^{39}$ In her work on women and labour during the Second World War, Carolyn Gossage asserts that, even as late as 2001, historians in the field of women in the war recognize this as "as segment of the population that might otherwise be buried in the sands of time and the Department and National Defense Archives." ${ }^{40}$ While much has been written on women and the war in recent years, the lack of existing scholarship on mothers of sons in active service and imprisoned overseas is a specific demographic that continues to be overlooked. The third chapter of this thesis offers an example of the influence and impact that women had in supporting their sons

${ }^{37}$ Jeffrey Keshen, Saints, Sinners, and Soldiers: Canada's Second World War (Vancouver: UBC Press, 2004), 146.

${ }^{38}$ Keshen, Saints, Sinners, and Soldiers, 146. For an example of the discussion which exists surrounding workingclass women in Britain, see James Hinton, Women, Social Leadership, and the Second World War: Continuities of Class (Oxford: Oxford University Press, 2002).

${ }^{39}$ Pierson's work does not make any reference to mothers. Keshen's does, but only in relation to 'working mothers' and 'mothers of illegitimate children.' A discussion of mothers of servicemen is left out of both of these works. ${ }^{40}$ Carolyn Gossage, Greatcoats and Glabour Boots: Canadian Women at War (1939-1945) (Toronto: Dundurn Press, 2001), 11-12. 
overseas. Gladys Miller was instrumental in providing a stabilizing link for her son - as did other mothers - through correspondence and the provision of parcels during active service and, more importantly, when he became a prisoner of war. Nothing has been published on the role that mothers played in sustaining their sons behind barbed wire overseas.

While mothers, specifically, are not incorporated into the historiography of the Canadian POW experience, there is a growing focus on families within the larger study of Allied captured servicemen. The 2010 publication, War and Welfare: British Prisoner of War Families, 1939-45, by Barbara Hately-Broad, examines the impact of having a loved one incarcerated overseas on their families at home. It is a work that was found late in the research for this thesis, and although it provided insight into "unofficial" channels for the communication of POW knowledge, it could only be incorporated into my research in a limited manner, although its conclusions bear out what is argued in this thesis. ${ }^{41}$ Additionally, as it focuses on the British family experience, there continues to remain no written discussion of Canadian POW families, and, for this reason, the third chapter of this thesis draws on a limited number of secondary sources and puts forward an original contribution to the study of Canadian women and war.

The Miller Collection allows for an intimate appreciation of an airman's Second World War experiences during active service and incarceration, and the important support from his mother on the home front. It breaks new ground in the discussion it provides regarding mothers on the Canadian home front as it extends beyond the well researched subject of women in uniform and focuses instead on the agency of mothers of servicemen. As a piece of family history, this collection of letters shares the story of my grandfather's war and it provides a first-

\footnotetext{
${ }^{41}$ Barbara Hately-Broad, War and Welfare: British POW families, 1939-1945 (Manchester: Manchester University
} Press, 2009). 
hand account of a four and a half year period that he largely kept from his wife and four daughters. 


\section{Chapter One: Sgt. Miller}

Erle Sinclair Miller's active service in the Royal Canadian Air Force from late August

1940 to September 1941 was formative in shaping his sense of self and appreciation for his home country. Coming from the small Ottawa Valley community of Castleford, Ontario, the nineteenyear-old airman was immersed in an unfamiliar environment, as his service life overseas was governed by the daily rituals surrounding his training and, later, by the rigors of operational sorties. ${ }^{42}$ It is clear from his letters to his mother during this period, however, that it was the friendships he made and his encounters with airmen from various Commonwealth countries that had the greatest influence on his time abroad. This chapter will explore his station experiences, his awareness of his role in the war and his growing attachment to Canada as elements that were informed through the sense of connection, camaraderie, and community that he experienced during his active service overseas from 5 September 1940 until the 7 September $1941 .^{43}$

Miller's developing identity as an airman was superimposed on his prewar role as a son and brother. Even though he was separated from his relatives, the constant flow of letters between Miller and his family in Castleford throughout his year of active service indicates that

\footnotetext{
${ }^{42}$ Miller's daily experiences, as captured in his letters, offer little insight into the strategic direction of the war, or his place within it. While the historiography surrounding the RCAF's development and role during the Second World War is considerable, an introduction to Canada's efforts from 1939-1945 can be found in: Leslie Robert, There Shall Be Wings: A History of the Royal Canadian Air Force (Toronto: Clarke, Irwin \& Company Limited, 1959), Larry Millberry, Canada's Air Force: At War and Peace (Toronto: CANAV Books, 2000), and Larry Millberry, Sixty Years: the RCAF and CF Air Command 1924-1984 (Toronto: CANAV Books, 1984).

${ }^{43}$ Upon his arrival in the UK, Miller was stationed with 112 (AC) Squadron High Post Aerodrome from the 6 September 1940 until the 11 December 1940, when he was transferred to the RCAF Pool Halton on December 11 1940. On 14 February 1941 he was moved to 400 Squadron, Odiham Hants, and then to 225 Squadron on 3 March 1941. Miller began his operational sorties with 207 Squadron, which he joined on 18 April 1941.

“Airman's/Airwoman's Record Sheet (Active Service) for Erle Sinclair Miller," Royal Canadian Air Force, Ottawa, Ontario, no date. For information on 112 squadron, see Samuel Kostenuk and John Griffin, RCAF: Squadron Histories and Aircraft, 1924-1968 (Toronto: Samuel Stevens Hakkert \& Company, 1977): 75-76 and "No 112 Squadron," Robert Brown, accessed 29 July 2012, http://www.rafweb.org/Sqn $111-115$. htm. The term "active service' is used throughout this study to denote Miller's period of RCAF training and flying.
} 
they were never far from his thoughts. ${ }^{44}$ Miller's letters are filled with what became familiar comments, such as, “Am looking forward to word from you. We haven't had any mail for quite a while." 45 These types of remarks occur frequently in the letters Miller sent home throughout the war, and suggest a deep reliance on his family's correspondence in order to sustain his connection with his home front community. This attachment to home was common throughout the war, and, as a result, it was customary of many in the armed forces to keep careful track of the mail that they sent and received. ${ }^{46}$ There are indications in the Miller Collection that Miller also monitored his mail: writing to his mother in August 1940 he observed: "My mail has been coming over to me inside of 20 days lately." ${ }^{, 47}$ This pace seemed to satisfy the young airman as his continued correspondence with his mother seemed to lessen the geographical distance that separated him from his family and friends in Castleford. In a later letter, a gap in mail delivery discouraged Miller and he hinted in a note home that, "Am looking forward to word from you. We haven't had any mail for quite a while. We've heard that a big convoy of mail was sunk so guess some cigs and letters for me have gone down."48 In addition to correspondence with his

\footnotetext{
${ }^{44}$ This connection to Castleford was maintained during his training and active service through the 66 letters he sent to his mother. He sent, on average, four or five letters a week, ranging from one to five pages, but the majority comprised of two pages, approximating 250 words.

${ }^{45}$ Erle Miller to Gladys Miller, 7 August 1940.

${ }^{46}$ Collections such as those of Squadron Leader George Urquhart Hill, Flight-Lieutenant Miller Gore Brittain, and Flight Officer Bob Wallace, archived at the Canadian War Museum, contain similar letters. F/O Wallace, for example, wrote to his girlfriend: "Well my little chickadee you better start explaining yourself as to why I haven't had any mail for ages and ages. I was telling Pat that I hadn't heard from you and he said maybe you had run off and got yourself married. I didn't think you would do that but you have got me wondering as to whether I have said something wrong. If I have said something wrong don't forget to tell me off about it but how about writing soon huh? You got all me all worried wondering what has happened." Norma Lee Collection, "Letter from Bob Wallace to Norma Lee, 17 July 1944," [58A 1 221.2] Canadian War Museum, Ottawa, Ontario.

${ }^{47}$ Erle Miller to Gladys Miller, 7 August 1940.

${ }^{48}$ Erle Miller to Gladys Miller, 26 September 1940. At this early point in the war, the sending and receiving of mail was severely affected by the Battle of the Atlantic. While Miller was aware of the fighting, he grew impatient with the delays in the postal service. Making matters worse, even when mail did arrive at air-bases in Britain, it could be stolen or even sold to other servicemen: "Apparently the mail man at 400 R.C.A.F. Squadron was selling some of the cigs and they have another one there now." Erle Miller to Gladys Miller, 24 February 1941.
} 
community in Castleford, Miller maintained a connection to the larger district of Renfrew by reading its weekly newspaper, the Renfrew Mercury. ${ }^{49}$

From Canada's declaration of war in September 1939 through to December 1940, the Renfrew Mercury presented its Ottawa Valley readership with extensive military coverage of the overseas conflict. The local paper published its first war-related article on 7 September 1939, four days after England and France had declared war on Germany and three days before Canada committed itself to the Allied effort. The main headline of this paper read: "War Declared! "Canada's Effort Will be Voluntary" says Premier King." ${ }^{50}$ Next to this direct title, appeared an article entitled, "Parliament Meeting To-day to Chart Dominion's Course During War," which discussed Canada's war plans and informed the local readership that:

For the second time since Confederation Parliament met Friday to define and chart Canada's course in a European war involving the British Empire. Prime Minister Mackenzie King announced Thursday that despairing of success for the peace efforts of the democratic powers, Parliament had been summoned for September 7 th. ${ }^{51}$

Through such initial coverage, this weekly publication presented its readership with journalism that supported the predominantly English-Canadian understanding that if Britain was at war, so too was Canada.

It was an appreciation of events that seemed to have been accepted by members of the Renfrew district as the op-ed columns of later pages echoed this understanding, with one declaring quite emphatically, "Britain at war! Canada at war!"52 This article went on to state that:

\footnotetext{
${ }^{49}$ This appreciation for the local newspaper is expressed in the following excerpt that Miller sent his mother in September 1940. "Write often as I enjoy your letter very much. Received the Mercury from Aunt Mabel to-day dated Aug. the 7th so that was pretty good. Thought that was nice of Aunt Mabel." Erle Miller to Gladys Miller, 5 September 1940.

${ }^{50}$ Renfrew Mercury, 7 September 1939.

${ }^{51}$ Ibid.

${ }^{52}$ Renfrew Mercury, 7 September 1939
} 
Sunday morning war against Germany was declared by Great Britain and at the same instant Canada was at war, although her Parliament had not formally declared so. The Canadian Prime Minister, over the radio, called upon all Canadians to stand ready to take such action as is becoming in her as part of the great British Commonwealth of Nations. ${ }^{53}$

The Renfrew Mercury promoted a narrative of solidarity with Britain, justifying the commitment because the Ottawa Valley community and its resources were potential targets of Axis aggression. ${ }^{54}$ This threat was illustrated in the sub-headline of the front page of the 7 September 1939 paper that announced, “The British Empire is Involved in Defence of Polish People -France has Declared War on Germany -- So also has Turkey -- United States Remains Neutral -Renfrew Power Houses and Water Supply Guarded."55 Through this coverage, the Renfrew Mercury presented the threat of Axis aggression within a community context that was directly relatable to its Ottawa Valley readership.

Alongside these accounts of events overseas and the potential targets on the home front, the Renfrew Mercury ran articles which suggested various forms of engagement within the war effort to its readership. On the second page of the 7 September paper, an article reported that "many towns announce enlistment places to permit young men to join the army, navy or air force

\footnotetext{
${ }^{53}$ Ibid. While Prime Minister King did not commit Canada in advance to "a course of action that would involve automatic participation in a European war," he believed that if it came to force, "Canada would, and should, stand with Britain." Michael Bliss, Right Honourable Men: The Descent of Canadian Politics from Macdonald to Chretien (Toronto: HarperCollins Publishers Ltd., 2004), 147.

${ }^{54}$ An article published 5 October 1939, entitled "Aliens of Renfrew and District Must Register!" read, "What is an alien? Well, for present purposes they are Germans who have come to Canada and have not taken out naturalization papers." "Canada is at war with Germany and her allies," continued the article, "and the registration is quite a necessary matter, therefore it should not be put off." While this article was not as threatening as the previously mentioned headline, it did point to sources of concern within the local community which were in keeping with the paper's larger war narrative. Renfrew Mercury, 5 October 1939.

35 Renfrew Mercury, 7 September 1939. This is an especially powerful title as Canada had not yet declared war against Germany, and was, therefore, not officially engaged in this military conflict. For further information on Renfrew's Hydro Plant, which dates to 1913, see "Renfrew Upper Plant Generating Station," Ontario Power Authority, accessed 21 July 2012, http://www.powerauthority.on.ca/hydroelectric/renfrew-upper-plant-generatingstation-099-mw-renfrew-bonnechere-river.
} 
to enlist," and that such an effort was "needed for the defence of the Empire."56 Four months later, on 25 January 1940, the Renfrew Mercury printed its first article that specifically targeted young Ottawa Valley men and urged them to enlist with the Royal Canadian Air Force (RCAF) ${ }^{57}$ While this article highlighted the expansion of the British Commonwealth Air Training Plan, its underlying message targeted the Renfrew Mercury's male readership and informed them that they would no longer "be required to travel a considerable distance to enlist," but could do so through a "mobile Air Force recruiting unit" that was touring through “Pembroke, Renfrew, Perth, Smith Falls, Brockville, Prescott, Cornwall, Valleyfield and Hawkesbury."58 This article was particularly powerful as no other call to arms had been published in the paper up until this point. With articles such as this, and the increased presence of RCAF related news and imagery throughout the spring and summer issues of 1940 , it was clear that both the Renfrew Mercury and RCAF recruiting agencies focused enlistment efforts on young, rural men. 59

Miller's decision to enlist was undoubtedly influenced by local perceptions of the Canadian war effort. On 5 May 1940, Miller, alongside John "Red" Maville (Ottawa, Ontario), Harvey Lacelle (Toronto, Ontario), Ray Bourgeois (Ottawa, Ontario), Stan Reid (Ottawa, Ontario), Smoky McLaughlin (Ottawa, Ontario), and Bernie Villeneuve (Marsville, Quebec), enlisted in Ottawa with the Royal Canadian Air Force Special Reserve, a newly formed branch

\footnotetext{
${ }^{56}$ Renfrew Mercury, 7 September 1939. As the war progressed, the paper continued to run articles throughout the fall of 1939 which captured the state of events overseas, and printed titles that boasted of Allied success abroad, such as "Allies "Comfortably" Winning the War!" which was published in the 23 November 1940 issue. Renfrew Mercury, 23 November 1940.

${ }^{57}$ This article was found on the front page of the Renfrew Mercury paper and its headline read, "Valley Young Men Now Have Opportunity to Enlist in the Royal Canadian Air Force." Renfrew Mercury, 25 January 1940.

${ }^{58}$ Renfrew Mercury, 25 January 1940. For an introduction to the literature on the BCATP, see F. J. Hatch, The Aerodrome of Democracy: Canada and the British Commonwealth Air Training Plan, 1939-1945 (Ottawa: Canadian Government Publishing Centre, 1983).

${ }^{59}$ Renfrew Mercury, 23 January 1940; Renfrew Mercury, 23 November 1940.
} 
of the RCAF. ${ }^{60}$ Miller was interviewed four days later, on 9 May. He was evaluated on his

suitability as a candidate for the RCAF based on his physical appearance and stature, flying

history and education level. ${ }^{61}$ The Miller Collection contains the formal report taken during this interview which described Miller as "healthy, slender, and ordinary" and his clothing as

"conservative poorly dressed but clean and neat."62 According to this report, Miller "wanted to

be a pilot and should qualify, but is coming in as Air Gunner in order to be called up earlier.",63

While Miller's interviewer, Flying Officer R.M. Cowan, rated him as "average" and deemed him

suitable in all respects for service in the RCAF, he was not recommended for a commission,

likely as a result of his level of education and lack of flying experience. Instead, Miller was

selected as a Private Air Gunner. ${ }^{64}$

\footnotetext{
${ }^{60}$ Special Reserve Interview Report. 9 May 1940. Recruiting Centre: Ottawa, Ontario. The six young men Miller enlisted with were not known to him at the time. They connected, however, over their shared excitement for active service and, even though their service and operations saw them through different stations, sorties and outcomes, these young men stayed in close contact with one another. The aircrew selection during the First World War had been a system that focused on "general merit," picking men who would do fairly well at almost anything. During the Second World War, specialized selection tests were designed to specifically predict success in training, accepting only those who had the best chance of completion. For an introduction to RCAF training, see English, The Cream of the Crop, 41-52.

${ }^{61}$ Intelligence was seen as the essential characteristic of good aircrew material, and one's level of education was, therefore, considered to be the best indicator of a candidate's intelligence. See English, The Cream of the Crop, 28. For an introduction to the role of education in training in the British army during the Second World War, see Jeremy Crang, The British Army and the People's War, 1939-1945 (Manchester: Manchester University Press, 2000), 90114.

${ }^{62}$ Special Reserve Interview Report. 9 May 1940. Recruiting Centre: Ottawa, Ontario. Other options under this category were, "rugged, medium, short, refined, coarse, untidy and dirty" and for dress, they were, "flashy, tasteful, smart, untidy," and, "careless." When it came to the category "Experience and Training (including Military) useful in the R.C.A.F." the interviewer wrote that Miller had, "3 years High School Cadet Corps."

${ }^{63}$ Special Reserve Interview Report. 9 May 1940. Recruiting Centre: Ottawa, Ontario. In addition to this interview, Miller would have had to pass a physical examination.

${ }^{64}$ Special Reserve Interview Report. 9 May 1940. Recruiting Centre: Ottawa, Ontario. Air Gunners were in charge of the operation of "machine guns and [...] of all types of gun turrets, deflection shooting including gunsights, range estimation, air to air and air to ground firing," as well as "aircraft recognition, including British, American, Russian, German, Japanese, and Italian Aircraft types and designs." Air Gunners were also required to have extensive knowledge of "armament and gunnery, including sights and sighting, gunnery procedure, machine guns, rifles, revolvers, cine-camera, gun turrets, small arms ammunition, skeet shooting, pyrotechnics." Miller's Flying Log Book affirms this 'Rear Gunner' status, in all but one of his 21 sorties. R.C.A.F., Observer's and Air Gunner's Flying Log Book, Erle Miller, May 3 1941. Additionally, Robert Kirby's book, Avro Manchester: The Legend behind the Lancaster, makes mention of 'Dusty Miller, the rear gunner," in describing the operational sortie that the crew of the L730 flew on September 7th, 1941. Robert Kirby, Avro Manchester: The Legend Behind the Lancaster (Leicester: Midland Publishing Limited, 1995), 99.
} 
Upon enlistment, Miller was sent for intensive training from June 6 to August 21, 1940 to the RCAF's most modern base in Trenton, Ontario. ${ }^{65}$ After a few weeks on Lysanders, Miller and his six colleagues prepared to embark for Europe. ${ }^{66}$ Their departure, however, was twice delayed by the threat of U-boat attacks, and they spent five anxious days aboard the Louis Pasteur in Halifax harbour, awaiting approval for sailing. ${ }^{67}$ Miller's first letter home displayed his impatience: "we haven't pulled out yet. Still in the harbour. Expect to pull out to-morrow never can tell though. Will be glad to get out of here and get a little action for a change. We are on the boat and can't get shore leave a-tall. It gets pretty monotonous with nothing to do a-tall." In that same letter, Miller's excitement cut through his general malaise, as he wrote to his mother of the fighting he hoped to do in the very near future: "We have been posted to the Machine Guns on the voyage over. Hope so. Wouldn't mind being attacked and maybe taking down a plane. That would probably set me right up for a good promotion."69 Miller's bravado in this letter reveals a lack of appreciation for the considerable difficulties besetting British shipping and the larger Allied effort on account of German U-boat action. Perhaps this sense of invincibility was a result of the Renfrew Mercury's limited coverage of this theatre of war, as the newspaper only published two articles and three images of Battle of the Atlantic and the U-boat threat between Canada's declaration of war and Miller's departure for Europe in the later

\footnotetext{
${ }^{65}$ Trenton became a major training centre during the Second World War under Canada's participation in the British Commonwealth Air Training Plan. Hatch, The Aerodrome of Democracy, 49.

${ }^{66}$ Lysanders "were small single engine planes used as army cooperation planes. Our army artillery would be firing off big canons and we would direct their aim from up in the sky and radio down to the gunners where to aim their big guns." Erle Miller to Alexander Wilson, 1991.

${ }^{67}$ The Pasteur, in light of her speed, generally made the crossing of the Atlantic alone and not as part of a convoy with a warship escort. In total, the Pasteur carried 220,000 troops, and 30,000 injured combatants, and traveled 370,669 miles during the Second World War. "The Long Voyage of the Ship Pasteur," accessed 13 March 2012, http://stoenworks.com/louis\%20pasteur.html.

${ }^{68}$ Erle Miller to Gladys Miller, 25 August 1940.

${ }^{69}$ Erle Miller to Gladys Miller, 25 August 1940.
} 
summer of $1940 .^{70}$ The last article that Miller could have read prior to his enlistment, loosely linked to this subject, was published in Renfrew Mercury on 28 March 1940 and presented an image of anti-aircraft guns and a commentary which read:

Nazi air attacks on British shipping have shown that the raiders don't enjoy being met by machine-gun fire from the small boats which have been their favorite prey. That is why the British navy's new highspeed motor torpedo boats are expected to be extremely effective in discouraging raids over the channel. Here is the crew of one of the speedy craft, looking for enemy planes off the east coast. The look-out gives wwarning[sic] and the anti-aircraft gun ners[sic[ go into action. $^{71}$

The servicemen aboard the Pasteur saw no action as they crossed the Atlantic, and while

Miller's hopes of immediate combat were dashed, he was very lucky given the increasing danger at sea. ${ }^{72}$

In spite of the uncertainty of the trans-Atlantic crossing, the letters Miller wrote to his family during his voyage across the ocean capture his excitement with his new wartime status. They also demonstrate the bonding which took place between young men setting off for war, and, as Miller conveyed in the following note home, his training with a fellow Canadian served as the platform for their friendship overseas:

It was a rough trip over but to give some entertainment to the troops, they organized a big boxing bout with the big ring just like professionals. A pal of mine (one of the seven that I trained with) had been the Bantam Weight Boxing Champion of Canada. He had also

\footnotetext{
${ }^{70}$ The Renfrew Mercury published its first article about the Battle of the Atlantic on September 28th, 1939. The title read "War Goes Slowly But Surely: British Navy Steadily Sinking Submarines, Banishing German Ships from the Seas, and Keeping the German Navy Bottled Up, is Gradually Closing in on Germany on all Sides." This coupled with a picture from the 2 November 1939 issue highlighting the newly improved and effective precautions used by the Allied convoys, could suggest to the readership that the German U-boat threat was under control. The text under the latter image read: "A new patrol system for the Allied merchant shipping has been put into force by the British navy. Apparently much faster than the old convoy service, it is described by a British skipper as like going from lamp post to lamp post. British war vessels lie in watchful little cluster serving like policemen in a relatively circumscribed beat." Renfrew Mercury, 2 November 1939.

${ }^{71}$ Renfrew Mercury, 28 March 1940.

${ }^{72}$ From June to October 1940 , over 270 Allied ships were sunk during a period which the U-boat crews commonly referred to as "The Happy Time". In August alone, German U-boats destroyed 267,618 tones of Allied ships and goods. Marc Milner, Battle of the Atlantic (St. Catharines, Ontario: Vanwell Publication, 2003), 34.
} 
fought in the Berlin Olympics in Germany in $1936 .{ }^{73}$ As you can see, he was a pretty good fighter. At any rate the champion boxer in the Navy challenged my pal Harvey LaSalle to fight him in the ring. I was Harvey's second. This is the guy that gives him water, rubs his face with a towel, in other words tries to make him more comfortable for the next round. Well the fight went very well until the fourth round and thats when my pal Harvey came in with a left and a right knocking the Navy champion out. Harvey declared Champion of the Louis Pasteur ship for the rest of the trip. ${ }^{74}$

After finally arriving in England on 25 August 1940, Miller remained with his six

Canadian friends but was eventually separated from most of his comrades and transferred into an RAF squadron. ${ }^{75}$ At this early point in the war, RCAF graduates arriving in Britain were just as likely to be posted to an RAF unit as to a distinctively Canadian one. ${ }^{76}$ This could sometimes lead to a host of rivalries and tensions amongst servicemen. ${ }^{77}$ While national allegiances created bureaucratic and service animosities for some, it also affected the ways in which Canadians came to understand themselves as participants in an international war effort. Some Canadians were treated in a patronizing and belittling manner by their wartime hosts, who quickly dismissed

\footnotetext{
${ }^{73}$ Harvey Lacelle was a Canadian boxer who did, as Miller's letter home suggests, compete in the 1936 Summer Olympics. There, he was eliminated in the first round of the bantamweight class after losing to Fidel Ortiz, who would later achieve a bronze medal in this division. "Harvey Lacelle," Hillary Evans, accessed July 3rd, 2012, http://www.sports-reference.com/olympics/athletes/la/herve-lacelles-1.html. He died on 28 June 1942. "Casualty Details," Commonwealth War Graves Commission, accessed 29 July 2012, http://www.cwgc.org/search-for-wardead/casualty/2033962/LACELLE,\%20JOSEPH\%20HARVEY\%20MILTON.

${ }^{74}$ Erle Miller to Alexander Wilson, 1991. Miller consistently spelt Harvey's last name incorrectly. One can assume, however, that as an anglophone, Miller simply confused the French 'celle' sound with 'salle'.

${ }^{75}$ Upon arriving overseas, he was posted to the RCAF reserve pool at Halton in south central England, one of the largest Royal Air Force stations in the UK. RAF Halton was established in 1919 by Lord Trenchard as the No. 1 School of Technical Training for RAF aircraft apprentices. During the Second World War, the base continued its training role. Additionally, No. 112 Squadron and No. 402 Squadron of the Royal Canadian Air Force were based at Halton for a part of the war.

${ }^{76}$ Larry Millberry and Hugh Halliday, The Royal Canadian Air Force at War 1939-1945, (Toronto: Canav Books, 1990), 67.

${ }^{77}$ One major source of tension was the fact that Canadians were better paid than their British cousins. In 1939, the basic pay of a Canadian private was $\$ 1.30$ a day, which was approximately five shillings and sixpence. British privates pay began at two shillings, roughly fifty cents, and increased based on their length of service and level of proficiency. At the height of their pay rate, British privates could receive four shillings. C.P. Stacey and Barbara Wilson, The Half-Million: The Canadians in Britain, 1939-1946 (Toronto: University of Toronto Press, 1987), 75. For an introduction to the establishments of these rates, and how they compare with the First World War, see Desmond Morton, Fight or Pay: Soldiers' Families in the Great War (Vancouver: UBC Press, 2004), 25-50.
} 
them as "colonials. ${ }^{78}$ In turn, some RCAF personnel resented the English as they believed there was no distinction to be made between the various Commonwealth dominions. ${ }^{79}$ Miller 's letters do not present such outward distain for his host country, but he did experience this rivalry first hand, and wrote of one occasion when he was in bed, "trying to concentrate on this letter" when his two friends were "arguing with two R.A.F. Gunners about the advantages Canada had over England." ${ }^{80}$ Generally speaking, Miller felt that the English were less than welcoming: "It's funny," he wrote in one letter to his mother, "you can always tell an airman in the R.A.F that comes from Scotland. They are always more obliging and friendly. We've noticed that time and again. The boys mostly always head for Scotland with their leave. They say the farther North you go the nicer the people." 81

On 15 February 1941, a day after his transfer from Halton Pool to No. 110 AC Squadron RCAF, Miller wrote home about his new surroundings: "From what we have seen of it so far we don't care for it any hell. They are strict as hell on discipline and parades every day. There is no loofing around here a-tall, buttons shined and boots at all times." ${ }^{82}$ While Miller was irritated by the rigors of this new station, he would later long to return to this station following a few months of training with No. 225 RAF Squadron at Tilstead in Wiltshire. ${ }^{83}$ His correspondence home throughout his service with No. 225 Squadron exemplifies the general

\footnotetext{
${ }^{78}$ This was a sentiment that echoed from Canada's involvement in the First World War. In his work on constructing and preserving Canada's war reputation, Dr. Tim Cook states that "despite frequent allusions to the country being populated by a race of sportsmen and hunters, the Canadians were not immediately viewed as an elite force. Drawn from the harsh dominion of the North, Canadians were seen as undisciplined, unruly troops who had proved their unconventional but adept fighting skills during the South African War; however, they were deemed more brawlers than soldiers." Tim Cook, Clio's Warriors: Canadian Historians and the Writing of the World Wars (Vancouver: UBC Press, 2006), 10.

${ }^{79}$ William Carter, Anglo-Canadian Wartime Relations, 1939-1945: RAF Bomber Command and No. 6 (Canadian) Group (New York: Garland Pub., 1991), 110.

${ }^{80}$ Erle Miller to Gladys Miller, 13 April 1941.

${ }^{81}$ Erle Miller to Gladys Miller, 13 March 1941.

${ }^{82}$ Erle Miller to Gladys Miller, 15 February 1941.

${ }^{83}$ For information on this squadron, see "225 Squadron," Royal Air Force, accessed 29 July 2012, http://www.raf.mod.uk/history/225squadron.cfm and "History of RAF Odiham," Royal Air Force, accessed 29 July 2012, http://www.raf.mod.uk/rafodiham/aboutus/history.cfm.
} 
dislike felt by many Canadians' for RAF discipline; a disdain that was only heightened by Miller's low opinion of British efficiency. Miller's frustration was also indicative of his developing sense of Canadian nationalism which was informed by his strong identification with fellow Canadian servicemen:

I've spent a little time now in a R.A.F Squadron which is supposed to be pretty good and don't let anyone tell you they are better than a Canadian Squad. In my opinion our Squadron in the \#400th[City of Toronto Squadron] which carries out the same work as this one is $50 \%$ better. You can't beat the Canadians I don't think. I never knew I was a Canadian so much as since I've come over here. ${ }^{84}$

The above mentioned sentiment was repeated in Miller's later letters, such as the one written on 1 April 1941, in which he fervently stated that, "I'm not a-tall fussy about the R.A.F Squadrons. I don't think they're as efficient as our own Squadrons." ${ }^{\text {, }}$ In that same letter, he wrote:

Am not fussy about R.A.F. Squadron. I prefer a Scotchman ahead of an Englishman any day. You can pick out the Scotch every shot. They are far more obliging and ready to help a lad. The only thing I like about this Squadron is the fact that we're getting a fair share of flying. Will be a lot better pleased when we arrive back at our own Squadron Royal "Canadian" Air Force."

Miller's identification and professed sense of superiority in this last quote is truly representative of the connection he felt with Canada, and how instinctively this association informed his experiences during his active service overseas. As his training in RAF squadrons continued,

\footnotetext{
${ }^{84}$ Erle Miller to Gladys Miller, 8 March 1941. No. 400 Squadron was formed in Canada as No. 110 City of Toronto (Army Co-operation) Squadron and in February 1940 it arrived in England with Lysander aircraft and was renumbered 400 Squadron. For information on 400 Squadron, see Ron W. Wylie, 400 (City of Toronto) Squadron History: 1932 to 1966 (Toronto: 400 Squadron, 1996), Samuel Kostenuk and John Griffin, RCAF: Squadron Histories and Aircraft, 1924-1968 (Toronto: Samuel Stevens Hakkert \& Company, 1977): 80-81, and "400 Tactical Helicopter Squadron," Royal Canadian Air Force, accessed 20 July 2012, http://www.rcaf-

arc.forces.gc.ca/ $\mathrm{v} / \mathrm{hst} /$ page-eng.asp?id=694. To avoid confusion among Commonwealth units flying in England, all Allied units were renumbered and the RCAF received the 400-499 block of numbers. Royal Canadian Air Force, RCAF Logbook: A Chronological outline of the Origin, Growth and Achievement of the Royal Canadian Air Force (Ottawa: King's Printer, 1949), 42.

${ }^{85}$ Erle Miller to Gladys Miller, 3 April 1941.

${ }^{86}$ Ibid.
} 
Miller's opinion of these units did not improve and these parochial and patriotic expressions became a mainstay of his correspondence to his family in Castleford. ${ }^{87}$

Compounding these tensions was the fact that RCAF airmen commonly had unrealistic expectations about their readiness for active service upon arrival in the United Kingdom. It proved initially frustrating to discover that they required more training in places like Cranwell and Yatesbury, because their instruction in Canada had not been as advanced as that which was provided by the RAF in Britain. ${ }^{88}$ Naturally, a certain amount of rivalry had been anticipated, but the extra months of training and the delayed entry into operational service remained a difficult reality for many. ${ }^{89}$ For Miller, however, this extra time on course brought about great validation as he found fulfillment in his studies. As early as a week into his first navigation course, on 5 September 1940, he reported: "Every thing is going fine with me Mom. I'm still on my course and enjoy it very much." 90 Courses, alongside training, were mainstays in the continuous routine of station life. Miller, for his part, appreciated this focus: "Everything is going pretty much the same as usual here," he wrote in February 1941, "with very little variation. I've take so damn

\footnotetext{
${ }^{87}$ In a letter dated 28 February 1941 , Miller wrote "I don't like this station near as well as the 112th but it really isn't bad. The discipline is more strict." Erle Miller to Gladys Miller, 28 February 1941. Again in March, Miller noted that, "I'm still in R.A.F. Squadron but really prefer a Canadian Squadron." Erle Miller to Gladys Miller, 15 March 1941. These tensions were exacerbated by the fact that morale hit a low point in 1940-41, because of shortfalls in bomber aircraft production, and the effects of the expansion plans, which caused a surplus of aircrew, which in turn led to underemployment and overcrowding. David Bashow, No Prouder Place: Canadians and the Bomber Command Experience, 1939 to 1945 (St. Catharines: Vanwell Publishing Limited, 2005), 82.

${ }^{88}$ For information on Cranwell and Yasterbury stations, see "RAF Cranwell," Royal Air Force, accessed 28 July 2012, http://www.raf.mod.uk/rafcranwell/. and "RAF Yatesbury Association," Yatesbury Association, accessed 28 July 2012, http://www.rafyatesbury.webs.com.

${ }^{89}$ As late as 1943, Canadians still needed training on RAF equipment as there were no operational aircraft in Canada. They also had to get used to the European weather and terrain. Carter, Anglo-Canadian Wartime Relations, 81 .

${ }^{90}$ Erle Miller to Gladys Miller, 5 September 1940. "This is about 4:30 in afternoon. This morning we had quite a nice lecture on Navigation. Find it pretty interesting. They give us a bunch of numbers say 281765 and tell us to give the pinpoint on the map. We can with these figures pick out to within 50 yards there point on the map. I like it fine. We're going to get right down to it and get all the low down on it. There is quite a bit to map and charting courses and if we put in bombers as wireless airgunners observers or pilots we have to have a thorough knowledge of it. We're having another test to-morrow in tactical and artillery reconnaissance. If that goes through O.K we should qualify by the end of the week." Erle Miller to Gladys Miller, 28 November 1940.
} 
many courses now that it's getting to be a habit. Not that I don't need it. There is always

something to learn."91

While Miller had been training as an air gunner, his attitude towards his service overseas became far more serious in the late spring and early summer of 1940 , as he began to diligently pursue becoming a pilot. ${ }^{92}$ This dedication was apparent in the tone and content of the letters he wrote home, such as the one sent on 2 May 1941, wherein he itemized all of the steps he had to take to achieve his goals:

To-day was the day I had to go before the Educational Officer and he gave me an exam in mathematics and I passed O.K. so he recommended me with sufficient intelligence to take a pilots' course. After that I had to go to Medical Officer and had over an hour's inspection or M.D. pilots medical. I passed that fine. It was pretty Stiff. Eyes and heart especially. Also blowing Mercury up in a tube and holding it there. This is just a beginning of the red tape I have to go through. It sure is stiff in the R.A.F. getting a pilots course. 1st I had to see the disciplinary (word cut out from other side of page) form requesting interview with C.O. Got that. End had to (word cut out from other side of page) in Orderly Room did that. 3rd had to pass education office did that. 4th pass the Medical Officer did that. Still got to go to another city before Board of Education which is the sticker and where a lot don't get through. They're the big shots and its just like being on trial. If I pass that I have to go before the Board of Health and if I pass that I then take a course on Navigation before I ever start to fly. My big sticker is the B.O. Education. They give a lot of questions on trigonometry which I've never taken. I'm going to start taking lessons at night by the Educational Officer and see if I can't learn enough about it to meet requirements. ${ }^{93}$

91 Erle Miller to Gladys Miller, 27 February 1941.

92 In late 1940 and early 1941, the Canadian home front was inundated with news of the Blitz. Saturday Night and Maclean's covered the Blitz extensively, with opinion pieces and first-hand accounts, while the CBC provided specialty radio programming such as We Have Been There which allowed Canadian's to hear first-hand stories of the Blitz. See Jonathan Vance, High Flight: Aviation and the Canadian Imagination (London: Penguin Canada, 2002), 233. During this period, the Renfrew Mercury limited its coverage of German offenses to its War Day-ByDay columns, which provided detailed accounts of the war in Europe, and were most often found on page three and four of the weekly publication. While its coverage of the Blitz was not as extensive as the previously mentioned prints, the majority of its war-related articles and images were in some way connected to Canada's air effort, either through the RCAF or RAF. Miller's letters home, therefore, in which he speaks of becoming a pilot, would have been in keeping with the home fronts appreciation of the importance of this service, and the strong presence that Canada's air force should have in defending Britain and attacking Germany.

${ }^{93}$ Erle Miller to Gladys Miller, 2 May 1941. Throughout his training, Miller took the following courses: Navigation, Radio Telegraphy, Engineering, Meteorology, Mathematics (regular and decimal fractions, metric systems, 
Even though Miller had to wait three months before he could begin his first pilot's course, it was a topic that was raised in nearly every letter he sent home during this period. ${ }^{94}$ After the course started in August 1941, however, his letters present a general coolness towards the whole undertaking and, as if burdened by the idea of mentioning his pilot's course once more, he noted: "You were asking about my pilot's course, I think I told you all the dope in previous letters, well at any rate I start in on the Navigation course day after to-morrow." 95 This reticence was perhaps an acknowledgement of the reality that not all airmen who took the pilot's course would, in fact, succeed. ${ }^{96}$

For Miller, as for many Canadians overseas, it was only after he had left the familiarity of home and spent time in a new environment that he was able to recognize and appreciate his Canadian identity, which was firmly grounded in the friendships he developed with fellow No. 400 Squadron members while in England. As they trained and experienced a collective overseas 'othering', RCAF airmen in the RAF most often found solace, companionship and a reaffirmed national strength and patriotism in their relationships with one another. These bonds, and their

averages, ratios, squares roots, elementary process of algebra, arithmetical generalization in formulas, laws of indices, measurement of angles, and triangular properties), and Gunnery. This was in addition to flight training. ${ }_{94}$ Miller mentioned his pilot's course in 16 pieces of correspondence that he sent home during this three month period.

${ }_{95}$ Erle Miller to Gladys Miller, 9 August 1941.

${ }^{96}$ A case in point was Flight Lieutenant Brittain of No. 78 Squadron, who failed his pilot's training because of two poor landings. In a letter he sent to his family, he recounted the details: "To-night I have bad news for you. I was on the point of going solo to-day - my instructor said I would do it another hour - and then I was sent up for a final check with the squadron commander and made two poor landings and consequently washed out as a pilot. Knowing what was at stake I was tense and spoiled things by levelling [sic] out at about 35 feet instead of 20 in the landing. He said he couldn't risk sending me solo when I was apt to do something like that and I supposed he was right although I tried awfully hard to change his mind. [...] Naturally, I feel tough about washing out but I have lots of company. There were seven total which brings the total to about $35 \%$ of the course. I haven't a great deal to talk about tonight so please excuse the brevity of this letter." Miller Brittain Collection, "Letter to Mrs. Brittain, 15 May 1943", [58A 1 82.8] Canadian War Museum, Ottawa, Ontario. The themes of this excerpt, the disappointment, the stress of service training, and the reassurance that others had also failed to meet the high standard were not apparent in Erle Miller's letters because, of course, his active service came to an abrupt end before his pilot training could be completed. 
significance to Miller, are apparent in the way in which he introduced his companions to his mother in the following correspondence:

Harvey swell guy - women can't resist him. Afraid of nothing but never looks for trouble or runs away from it. Goes after anything he wants and good pal. Awfully neat - goes for married women. Willy is mischievous but awfully good-hearted and never sees a guy stuck for anything. Sloppy dresser. Ray not much into girls. Enjoys shows and beers. McLaughlin quite smart - lot initiative, dam mischievous and always talks his way out. Maville quite smart. Farmer ways about him. I never have seen anyone yet from Ottawa that I know or from any where but sure know a gang now. I get along quite well and have lost a lot of my timidness. ${ }^{97}$

While Miller made note again of his "good-pal" friendship with Harvey, in this piece of correspondence he also informed his mother of his friend's considerable sway over the opposite sex. ${ }^{98}$ The suitability of this topic for a letter sent to a mother is suspect, but it clearly illustrates that Miller respected his friend's 'talent'; Ray lacked such tact, and Miller made note of this to his mother. His attention to Willy's "sloppy" presentation and Harvey's "awfully neat" attire also suggests that Miller cared about his own appearance. ${ }^{99}$ These general comments drew his mother's attention to the qualities he respected or noticed in others, which in turn, subtly suggested to her the type of young man he was becoming.

As censorship regulations did not permit airmen to discuss their active service and operational history in their correspondence with the home front, Miller shared anecdotes of his life overseas instead. The following comment from a letter Miller sent home in December, 1940, for example, offered insight into his lifestyle, his friendships, his homesickness for Canada, and the pride he took from being part of the RCAF, all without mentioning his active service:

\footnotetext{
${ }^{97}$ Erle Miller to Gladys Miller, 15 March 1941.

${ }^{98}$ Erle Miller to Gladys Miller, 15 March 1941.

${ }^{99}$ Ibid.
} 
This is Thursday night and I have just come from the show. We went into the mess and had a nice toasted sandwich and a cup of oxo. Boy oh boy the show was wonderful. It was called "Untamed" and was in Canada quite a while ago. It was all about Canada in the wilds in Technesoleur. This doc in the States was told to take a trip for change so he took geography and opened it up to a map of Canada. There was seven Sergeant Air Gunners sitting with me and we all stood up and clapped. It was hunting and fishing. Good Old Canada. Boy when I get back home I'm going on a fishing trip and sleep and eat till my hearts content. ${ }^{100}$

As these men spent more time together, either serving, training or taking part in station life, they developed nicknames for one another as expressions of their friendship. ${ }^{101}$ Miller had, by this point, already written many times about his friend John Maville using the nickname "Red," but on the 23rd of June, 1941, he wrote home about his own nom de guerre, stating, "my name over here is Dusty, Texas or Canada. I get Dusty more than any one though."102 Miller embraced this name and from this point on ended a few letters by signing 'Dusty'. The name continued to be used long after the war, as his grandchildren would later come to lovingly refer to him as "Papa Dusty".

\footnotetext{
${ }^{100}$ Erle Miller to Gladys Miller, 19 December 1940. This feeling of "Good Ol' Canada" is present throughout Miller's letters, and it can be inferred through such correspondence that he quite simply would have rather been home. While Miller's general attitude towards service was quite positive, especially as the opportunity to become a pilot became a reality, he often wrote home with sentiments that echoed the following, "You don't have to worry about me. I'm getting along fine and enjoy this life fine. I'll admit I'd rather be in Canada any day but who wouldn't rather be in his home country." Erle Miller to Gladys Miller, 30 November 1940. In a later letter he wrote, "this is the first of April and hope I'm home this time next year. It really isn't a bad life over here and I can't kick a-tall but would sooner have Canada in place of fifty Englands." Erle Miller to Gladys Miller, 1 April 1941.

${ }^{101}$ While Miller's letters made note of going to see shows with fellow airmen, these were not the only leisure pursuits in the RAF. In his work The Flyer, Martin Francis states that, "Flyers would go to movies or the theatre, take fishing trips, put on amateur dramatic shows or revues, play cricket or football on spare greens spaces on the airfield, or play pool in the mess. Given that flyers often spent a great deal of time waiting to go into action at the dispersal hut, card games were inevitably popular." Martin Francis, The Flyer: British Culture and the Royal Air Force (New York: Oxford University Press, 2008), 36.

${ }^{102}$ Erle Miller to Gladys Miller, 23 June 1941. For nick names see http://www.readyayeready.com/navy-life/navynicknames.htm, which links servicemen's surnames to their most commonly associated nickname. Erle Miller was likely given the nick name 'Dusty' as a miller gets dusty grinding flour. "Navy Nick Names," accessed 18 June 2012, http://www.readyayeready.com/navy-life/navy-nicknames.htm.
} 
While Miller's station life at this point revolved primarily around courses and training, it was also filled with the requirements of daily routine, which could be interspersed with trips to local towns or, when leave permitted, larger centres. Miller found his time with No.110 Squadron to be highly regimented and he was unimpressed by the remote location of the base. A few days after his arrival in Odiham (Hampshire, England), he reported to his mother in a letter that, "the nearest town is 11 miles away and we have to be in by 12 . There is a little village about $11 / 2$ miles from here but it is as dead as a door nail." 103 While the opportunity for leave remained uncertain, Miller did receive an annual week's leave over his first Christmas on active service. ${ }^{104} \mathrm{He}$ took this opportunity to travel with Ray and Red to Scotland, which was roughly $725 \mathrm{~km}$ from their training station, and while en route, the young lads had a bit of a misadventure:

Boy oh boy the train was crowded. The trains here are entirely different from our own. The coaches are divided into separate compartments and the only way you can get in is from the outside by doors so you see there will probably be $\mathbf{1 5}$ doors on each side of a coach. Ray, Red and I had to stand most of the way. We got about half way to our destination and decided we'd try to get another coach. From the coach door to the ground its about 4 foot drop but when you pull up at a station the door is about level with the cement platform. Well the train stopped and we jumped out and tried to find another coach with fewer people in it but it started up before we could find one and we couldn't get back in. There we were stranded in the city of Nuneaton about 3 in the morning. ${ }^{105}$

\footnotetext{
${ }^{103}$ Erle Miller to Gladys Miller, 14 February 1941 . The conditions at Odiham were crowded as the facilities were shared between 400 Squadron and a large contingent of French pilots and ground crews that had escaped the fall of France. After Dunkirk, this station experienced serious shortages and essential training was curtailed due to a lack of gasoline and spare parts. Wylie, 400 (City of Toronto) Squadron History, 30.

${ }_{104}$ Men were granted 'annual' or 'in rations' leave. The former was leave which could, generally speaking, be counted on, where as the latter form of leave came about when men had served a certain number of operations, fulfilled training requirements or their training officers permitted it. For more information on RCAF leave, see Stacey and Wilson, The Half-Million, 98-112.

${ }^{105}$ Erle Miller to Gladys Miller, 23 December 1940.
} 
Being stranded in a foreign and relatively isolated town did not upset the young men too much, but Miller, for one, was struck by the enforced darkness that befell the local community. ${ }^{106}$ In describing his leave, he noted, "the cities and towns are all blacked out. The only lights visible are traffic lights and they have shades over them so that they're not visible from the air. All the places are closed about 10 o'clock except in big cities."107

Accounts of black-out conditions were matched in Miller's letters home by tales of the wealth of entertainment and amusement that densely populated centres, such as Glasgow and London, offered allied airmen. ${ }^{108}$ The Young Men's Christian Association provided inexpensive accommodation and guides for visiting servicemen, such as the "The Canadian Soldiers' Sailors' and Airmen's Leave Guide for London," as well as "The Canadian Soldier's Guide to London," which offered its readership basic London information, including dining spots, tourist sites, and details on Canadian specific amenities and maps. ${ }^{109}$ Canadian airmen were drawn to, almost instinctively, venues such as the Beaver Overseas Club, theatres, cinemas and pubs. ${ }^{110}$ These were sites where Canadians were well received and often enjoyed special privileges, which Miller noted in a letter home on July 5th: "I' $m$ at the Beaver Club in London at the present and have just filled up on some nice Canadian food and polished it off with a couple of ice cold

\footnotetext{
${ }^{106}$ First hand experience with blackouts is a common feature in the correspondence sent home from airmen overseas. Flight Lieutenant Warren Duffy, for example, wrote home that, "I'm getting quite proficient at finding my way about in the blackout now, and when they say blackout, they aren't fooling. The first night I was amazed but now I feel like a veteran, or almost." Warren Duffy Collection, "Letter to Mrs. Duffy, 18 October 1941", [58A 1 231.4] Canadian War Museum, Ottawa, Ontario. Similarly, Flight Lieutenant Brittain wrote, "Flying at night in the blackout is quite the experience and trying to map read is by no means easy. I didn't know where I was last night but that was my first night trip and one gets used to it I hear." Miller Brittain Collection, "Letter to Mrs. Brittain, 22 March 1944", [58.A 1 82.8] Canadian War Museum, Ottawa, Ontario.

${ }^{107}$ Erle Miller to Gladys Miller, 23 December 1940.

${ }^{108}$ Miller spent a one week leave in Glasgow, Scotland, from the 21 to the 28 December 1940, for the Christmas holiday.

${ }^{109}$ These brochures were first published by the Canadian YMCA in 1940.

${ }^{110}$ The Beaver Club was enormously popular amongst Canadian servicemen as it offered a wide variety of services, such as a canteen with Canadian style food, reading, and writing rooms, an Information Bureau, banking facilities, showers and baths, and a barber shop. Stacey, The Half-Million, 1987, 102.
} 
cokes."111 In addition to the dining culture offered in London, Miller also sought out live music, and on his first foray into the city he took in, "one of these Scottish operas with violins etc. It was a 50 piece orchestra and one of these high stuff Beethoven's Concerto etc..."112

Leave also presented an opportunity to interact with the opposite sex. While such relationships sporadically appear in Miller's correspondence home, they also served as anecdotes which he used to 'protect' his younger sister, Marg, by making her aware of the real interests of young service men. Miller was deeply interested in her well-being and ended almost every piece of correspondence he sent during this period with a question or two about her. While the majority of these questions were connected, in some way, to her new job in Ottawa, he was also very curious about her romantic relationships and, as his time overseas progressed, he began to take increasing liberties in offering up his opinions on how she should conduct herself with the opposite sex during the war. On August 25th, 1940, he asked his mother, "Has Marg heard from Walter? She'll be looking for another boyfriend. Guess they are pretty scarce in Renfrew now," and several months later, on December 17th, 1940, he empathized, "Sorry to hear that Walter and Marg have broken up. It seems a trifling little thing at war time but am sorry to hear about it. If I was her I'd watch her air force chum. They generally have a girl in every port. I know I have but nothing serious."113 While these comments were playful in tone, they provide insight into Miller's conception of the relationships he had with female members of the local community during his active service in England, as well as those he fostered during periods of leave. As a

\footnotetext{
III Erle Miller to Gladys Miller, 5 July 1941. This letter was written on 'Beaver Club' letter head paper.

${ }^{112}$ Erle Miller to Gladys Miller, 23 December 1940. Miller wrote home of having seen 'Till We Meet Again,' 'Gone with the Wind' and Untamed. In July 1941, Miller spent a week in London, from 4 to 11 July 1941.

${ }^{113}$ These notes reflect the larger collection of questions and concerns that Miller expressed towards his younger sister during his active service with the RCAF. While the majority of these letters were made up of fairly traditional questions surrounds Marg's life, schooling and new employment, Miller's big brother bravado pierced through a few of the letters he sent to his mother. A fairly rude example of this can be found in the letter he sent on 15 August 1941, where he wrote, "Glad to hear Marg is buckling in and helping out with the work. She'll be getting to be quite a lady now. Tell her she better watch she doesn't get any fatter or she'll have a time getting a boyfriend ( ha ha)." Erle Miller to Gladys Miller, 15 August 1941.
} 
young enlisted man, Miller's service with the RCAF was not only heavily structured, but predominantly masculine. Leave from this relative uniformity, in both schedule and gender, meant a chance to interact with young ladies in an informal way and Miller noted in a letter home that, "the girls over here are overly friendly especially to the Canadians. We seem to be awful popular in England and Scotland."114 It was these relationships, and the way in which they were construed by the men on the station, that provided Miller with the grounds to make such 'informed' comments to his mother in regards to his sister. Such commentary presents Miller as both a concerned 'older brother' and a 'young airman' who knew first hand how many young men his age valued the companionship of the opposite sex. ${ }^{115}$ Miller may have been cordial towards those he dated, but his letters home express an understanding that not all airmen were as chivalrous. ${ }^{116}$

While social opportunities and gendered interactions influenced Miller's opinion of his new environment, his nutritional diet, and how it was met, had a central role in determining his opinion of a station. While Miller ate very well with No. 110 Squadron, writing home often about eggs, steak and chips, he was less than thrilled over the mess fees: "The meals are O.K.

${ }^{114}$ Erle Miller to Gladys Miller, 20 June 1940.

115 While Miller expressed this 'appreciation' in a great many letters he sent to his mother during his active service, writing about the girls he knew from home and those he was meeting overseas, he did not have the same 'openness' with Marg. For one introduction to the relationship between British women and Allied servicemen, see John Costello Love, Sex and War: Changing Values 1939-1945 (London: Williams Collins Sons and Company Limited, 1985): 309-333.

${ }^{116}$ While negative reactions to the opposite sex were not the norm, one example of this dissatisfaction can be seen in the following excerpt sent from F/L McCaig No. 426 Squadron to Henry Wright (Quebec): "One entente cordiale does exist between the servicemen and the women of this island. Air raid shelters, hay stacks, telephone kiosks and park benches take on a new significance since blackout it in vogue. And they're not attractive either. Age is no obstacle and I recall an incident of a 'pork sandwich' at The Old Homestead or some such name. That old gal was a prune. The women don't wait for someone to buy drinks in the pubs. They get in the queue and buy their own. I walked into town on Sat and incidentally walked hope afterwards. The Red Lion is the best and if it had a floorshow it would be a worse dive than the Bellrue Grill. The pub is a place to spend the evening and concentrate on drinking." Leslie McCaig Collection, "Letter to Henry Wright, 15 December 1942", [58A 1 227.3] Canadian War Museum, Ottawa, Ontario. 
but we have to pay a mess bill of around 25 shills a month which is a pretty high rate."117 This nutritional issue reflected the larger influence that wartime conditions in England had on members of the RCAF, who complained frequently about the quality and quantity of food that they received. Miller proudly boasted to his mum that, "I was telling some of the R.A.F. that eggs only 18 cents and they're 60 cents here but trouble is you can't get them. If you go in to a restaurant you can only order 1 egg." ${ }^{118}$ Miller was generally satisfied with the amount of food he received while on station, noting home that, "They're rationed here at the canteen. It would be hard for you to realize how food is rationed. We're getting well fed here though. Fact is I've never gone hungry yet." 119

Miller's opinion of station life was also greatly influenced by the opportunities he had to enjoy the company of the other Canadians. He would often engage in leisurely after dinner pursuits such as table-tennis, darts or listening to the radio. However, Miller complained frequently of the poor heating, an issue that plagued many servicemen, and he wrote home of one humorous, close-quarters event:

I had a bit of a hectic night last night. I wakened up with 2 big 75 lbs dogs lying on my feet about 2.30 in the morning. Smitty has a big red dog and Smokey has a big spotted bugger and they sleep in the hall. Well our door must have opened and the dogs came in and went to sleep on my feet. I tell you they got some sweet kicks on the a _ from me. Boy that made me sore. ${ }^{120}$

\footnotetext{
117 Erle Miller to Gladys Miller, 15 February 1941. This was a relatively low mess fee, as Miller was paid $\$ 1.30$ per day with separation allowance of $\$ 35$ per month. Stacey, The Half-Million, 1987, 75. The Renfrew Mercury's article titled "War Pay!" declared that this was a sizable pay increase "compared with $\$ 1.10$ per day and $\$ 20$ per month in 1914." Renfrew Mercury. September 11, 1939. Over the course of the war, shortages and queues in Britain persisted and, in fact, grew worse. Angus Calder, The People's War: Britain 1939-1945 (London: PIMLICO, 1992), 240.

${ }_{118}$ Erle Miller to Gladys Miller, 21 March 1941.

${ }^{119}$ Erle Miller to Gladys Miller, 3 April 1941. While Miller spent money on leave, he also sent home considerable amounts of each paycheck to his family, and wrote often that his family should use his money as their own, for example, "Say Mom don't forget and get presents for you, Dad, Marg and Marg. K. Let money be no object." Erle Miller to Gladys Miller, 28 November 1940. In February 1941, Miller sent a note home informing his mum as to the amount of money she should expect to receive: "You say you received my $\$ 26.00$ cheques well it should be $\$ 46.00$ real soon. You see I'm sending home $\$ 46+\$ 4$ for insurance now for over a month and half now so it should be starting home shortly." Erle Miller to Gladys Miller, 27 February 1941.

${ }^{120}$ Erle Miller to Gladys Miller, 24 February 1941.
} 
In March of 1941, Miller was transferred to No. 225 Squadron, alongside Red and Mack, and his opinion of this new station was less than favourable: "It is only for a month," he wrote in a letter home, "in which to get in some firing and flying and then we return to our own unit. It is a pretty muddy hole but think we can stand it O.K." ${ }^{121}$ While he didn't care much for this station, his correspondence home during this period offers the most insight into his daily routines while in training: "Get up in the morning around 8 have breakfast. Out to flight till noon, dinner out to flight till 4:30 then have tea and then to our room. Supper at 7.30 listen to radio, write letters and go to bed. We always have four meals in the R.A.F. This is one of those old English villages that you see in the movies." 122

Miller was transferred to No. 207 Squadron at Cranfield, in April 1941, and it quickly became his favourite squadron. ${ }^{123}$ Even though Miller had drawn great comfort from his Canadian companions in other squadrons, he reveled in the luxuries at this RAF station. In his first piece of correspondence from RAF Waddington, he wrote home of his new amenities:

In the recreation room which is about the size of or maybe larger than the public library at home is filled with big easy chesterfields and chairs, Radio, gramophone, piano, dart boards which are a common thing over here. There is a pool room next door and a canteen. We have a dandy room. Red and I are the only two Canadians here. There is almost 10 rooms in our house. Five on each side and a hall in the middle. The house is central heated and we have 2 sets coils in our room, two (word cut from other side of page) with sheets and a table

\footnotetext{
${ }^{121}$ Erle Miller to Gladys Miller, 3 March 1941.

${ }^{122}$ Erle Miller to Gladys Miller, 11 April 1941.

${ }^{123} 207$ Squadron had begun its service during the Second World War as a training squadron. In November 1940, it was the first to be equipped with the Avro Manchester and operations were commenced with this aircraft in February 1941 and, as Miller would experience first hand, it was an aircraft plagued by technical troubles. In March 1942, 207 Squadron converted to Lancasters. Kirby, Avro Manchester, 1995, 33. Martin Middlebrook and Chris Everitt, The Bomber Command War Diaries: An Operational Reference Book 1939-1945 (London: Midland Publishing Limited, 2011), 755. For more information on this squadron, see John Hamlin, Always Prepared: The Story of 207 Squadron Royal Air Force (London: Air Britain Historians Limited, 1999), and "Bomber Command No. 207 Squadron," Royal Air Force, accessed 29 July 2012, http://www.raf.mod.uk/history/bombercommandno207squadron.cfm.
} 
radio. Next room to us is the lavatory with 2 baths and two shower and nice marble basins. [words cut from other page] nice and clean. ${ }^{124}$

In addition to these new perks, Miller also began to fly operations while stationed with No. 207 Squadron and this, more than any other factor, affected his high opinion of the station. ${ }^{125}$ Miller's operational debut in the spring of 1941 coincided with a wave of German successes at sea which redirected the main Bomber Command campaign to cities and sites associated with the production of the German navy. ${ }^{126}$ With the very real possibility that Britain's vital ocean links with North America could be severed, Prime Minister Churchill instructed Bomber Command to focus all operational efforts for the next four months on those targets which presented a threat to British shipping. In a directive sent to the Air Ministry on March 9th, 1941, Churchill stated that, "we must take the offensive against the U-boat and Focke-Wulf wherever we can and whenever we can. The U-boat at sea must be hunted, the Uboat in the building yard or in the dock must be bombed. The Focke-Wulf, and other bombers employed against our shipping, must be attacked in the air and in their nests."127 With this change came the gradual acceptance of cities as legitimate targets, as they housed the resources

\footnotetext{
${ }^{124}$ Erle Miller to Gladys Miller, 18 April 1941.

${ }^{125}$ Miller was transferred to 207 Squadron on April 18th, but did not fly his first operation until the 3rd of May. R.C.A.F., Observer's and Air Gunner's Flying Log Book, Erle Miller, May 3 1941. For other accounts of RAF airmen and their experiences overseas, see Douglas Harvey, Boys, Bombs, and Brussels Sprouts (Toronto: McClelland \& Stewart Inc., 1981), and Stephen King, ed., "Your Loving Son": Letters of an RCAF Navigator (Regina: Canadian Plains Research Center, 2002).

${ }_{126}$ Between the Fall of France and 1 July 1941 , nearly 900 British, Allied and neutral ships carrying stores for Britain had been sunk by German naval forces and aircraft. While the Royal Navy was short of escort vessels and no long-range air escort was available, the German battler-cruisers Scharnhorst and Gneisenau were out in the Atlantic, sinking or capturing merchant ships. What Hitler had failed to achieve by the air attack and intimidation in 1940s his U-boats, surface warships and maritime bombers were close to achieving in 1941. Ken Delve and Peter Jacobs, The Six-Year Offensive: Bomber Command in World War Two (Bath: Bath Press, 1992), 131.

${ }_{127}$ Middlebrook, The Bomber Command War Diaries, 131-132. For more information on selection of German oil targets, see Ronald Cooke and Roy Nesbit, Target, Hitler's Oil: Allied Attacks on German Oil Supplies, 1939-1945 (London: HarperCollins Distribution Services, 1985).
} 
necessary for supplying Germany's naval forces. ${ }^{128}$ As attempts to strike strategic and specific targets gave way to area bombing, heavier civilian death tolls became the new 'reality' of the war from the air. ${ }^{129}$

Miller's first operational sortie, on 3 May 1941, fell almost a year to the day after his enlistment in Ottawa, and this month also marked the first time that the Manchester had been equipped to carry the new 4,000 lb. high capacity bombs, known as 'Cookies' ${ }^{130}$ As Miller and the crew of an Avro Manchester Mk.1, serial number 7377, flown by Flight Lieutenant W. J. Lewis D.F.C, headed for Cologne alongside 100 other aircraft, their payload incorporated this new, more powerful, bomb. ${ }^{131}$ While the sky was filled with thick clouds, causing very poor bombing conditions, Lewis attacked Cologne from 12,000ft, and Miller remarked in his Flying Log Book that that the crew successfully dropped one $4,000 \mathrm{lb}$. bomb on the city. ${ }^{132}$ Subsequent

\footnotetext{
${ }^{128}$ Spencer Dunmore and William Carter, Reap the Whirlwind: The Untold Story of 6 Group, Canada's Bomber Force of World War II (Toronto: McClelland \& Stewart Inc., 1991), 5.

${ }^{129}$ Churchill's scientific advisor, Lord Cherwell, had ordered D.M.Butt of the War Cabinet Secretariat to study the accuracy of Bomber Command's bombing by night using crew's logbooks and target photographs. According to the finding of the Butt Report only one in three of aircraft that claimed successful operations were within five miles of their aiming points. It read, "During moon periods, only one in four photographs taken on raids to German and French targets showed that the bombs had dropped within five miles of the target. In non-moon periods the proportion within five miles dropped to one in fifteen photographs; over Germany only, the figure was one in twenty, and the results over the important Ruhr industrial area were even worse than that." Butt Report as cited in Bashow, No Prouder Place, 2005, 65. For information on the changing nature of target selection, see Randall T. Wakelam, The Science of Bombing: Operational Research in RAF Bomber Command (Toronto: University of Toronto Press, 2009), 48-64. The air and ground crews of Bomber Command, however, knew nothing of these problems. Spencer Dunmore, Above and Beyond: The Canadians' War in the Air, 1939-1945 (Toronto: McClelland and Stewart Inc., 1996), 108-109.

${ }^{130}$ R.C.A.F. Observer's and Air Gunner's Flying Log Book, Erle Miller, May 3 1941. At the start of the war the standard ordinance was the 250-lb and 500-lb high explosive bomb. The 500-pound General Purpose demotion bomb was redefined and became the RAF's wartime "workhorse." However, the most dramatic ordnance introduced in 1941 was the 4,000 lb. "cookie" blast bomb. On March 31st, this "new high-capacity weapon was used for the first time on operations, by Wellingtons against Emden. By the end of May, it was in frequent use. Bashow, No Prouder Place, 42.

${ }^{131}$ Kirby, Avro Manchester, 1995, 69. That night, L7377, was one of two Manchesters, 27 Hampdens, 35 Whitleys and 37 Wellingtons dispatched to attack Cologne. That same evening, 33 aircraft, were sent to Brest. These planes suffered no losses and the pilots claimed to have accurately bombed their target. May 3rd also witnessed a minor operation of 9 Wellingtons and Whitleys to Rotterdam. Middlebrook, The Bomber Command War Diaries, 152. While Sergeant Jim Duncan of L7377 claimed that his aircraft's bomb hit their aiming point, P/O Gardiner of L7316 was unable to ascertain the effect of his bomb. Kirby, Avro Manchester, 69.

${ }^{132}$ R.C.A.F. Observer's and Air Gunner's Flying Log Book, Erle Miller, 3 May 1941. Miller also tabulated the length of his first op. at 5.05 hours.
} 
to releasing their payload, however, Lewis dove to about $2,000 \mathrm{ft}$, over the target, which gave

Miller and the other gunners an opportunity to suppress the town's defences by firing on searchlights and flak batteries. ${ }^{133}$ In a letter written many decades later, Dusty recounted his first operational experience to his eldest grandson, Alex Wilson. Able to express his experience in far greater detail than he could have during the war, Miller wrote:

I had made my first bombings trip over Germany and it turned out to be one of my worst trips. These were night trips and this one we got into several ack ack traps and one fighter plane zone. We managed to get back home in the morning with huge holes in the wings caused by enemy shells and almost out of gas. I asked one of the crew when we got back, how he rated that trip and he said "just about normal" - I thought to myself, "I don't want to see a bad trip.",134

As a result of the raid on Cologne, ground reports indicate that approximately 8 to 10 bomb loads struck the city centre, causing only minor property damage but killing 11 civilians. ${ }^{135}$

Miller's second operation on 8 May 1941, while seen as a success for Bomber Command writ large, was a failure for his crew, as he noted in his log book that the "bomb doors failed to open" over Hamburg. ${ }^{136}$ Three nights later, on 12 May 1941, Miller and the crew of L7322 departed for Mannheim, alongside 104 other aircraft. While Miller did not mention the failed Hamburg sortie to his family in Castleford, he wrote home on the 13th with great vigor about this operation: "was over Germany last night and we sure gave them hell. Mannheim was our objective. Everything went smooth." ${ }^{137}$ This statement in his correspondence home was a blatant lie as to the realities of how previous night's events unfolded. As recalled by Lewis, the sortie of

\footnotetext{
${ }^{133}$ R.C.A.F. Wireless Operator/Air Gunner's Flying Log Book, Jim Duncan, 3 May 1941, quoted in Kirby, Avro Manchester, 99.

134 Erle Miller to Alexander Wilson, 1991.

135 Middlebrook, The Bomber Command War Diaries, 152.

${ }^{136}$ The total effort for that night was a new record of 364 sorties with 10 aircraft (2.7\%) lost; the previous record had been 265 sorties on January 10/11 of February 1941. Ibid.

${ }^{137}$ Erle Miller to Gladys Miller, 13 May 1940. In that same letter, however, Miller expressed concern over his family's thoughts and possible worries about his trips in the air: "Say Mom," he wrote, "I hope you don't worry about me on my little flips. I debated with myself whether I should say anything or not and now I kind of wish I hadn't. It isn't as bad as it sounds a-tall, fact is I enjoy it."
} 
May the 12th was plagued by engine issues, common to the Manchester, and other unfortunate circumstances:

On May 12th I acquired a new aircraft, L7322, which as far as I was concerned, was the best Manchester I ever flew and it became pretty well my personal aircraft until I completed my tour. However, it had its teething problems. On this night we set out for a raid on Mannheim, but by the time we got well south of Cologne, the starboard engine oil temperature rose to the danger mark, the pressure dropped and I was forced to drop my bomb from $16,000 \mathrm{ft}$ on my alternate target, which was the railway station at Koblenz, and return to base. The arrival back at base was far more hair-raising that the operational trip in and out over enemy territory. We arrived back at base still with low oil pressure and the temperature in the starboard engine nearly off the clock, to find an intruder in the circuit. The flying control officer at Waddington refused to put on any lights whatsoever whereby I could carry out a landing. The wind was in the east that night, which necessitated coming around the west and turning over the village of Waddington, the airfield married quarters and landing towards the east.

Of course, of all the things that had to happen, the local air defence corps on the air field operating one of their searchlights decided to illuminate me and having done so sat with the light on me for a considerable time, naturally providing a nice target for the intruder as well as blinding me. I could only get rid of the thing by firing off the colour of the day, which was a most undesirable act as the intruder would obviously see it and could possibly copy it.

I did a very tight circuit and used no lights until I arrived over the boundary of the airfield, at which time I turned on the landing lights and put L7322 down. As soon as I landed I turned the lights off again. I had no sooner accomplished this and was still braking on my landing run when the intruder laid down a stick of four bombs, about 400 yards to my starboard side and parallel with my heading. We ended up taxying to our dispersal using flashlights to find our way through the hedges. The searchlight crew were personna non grata for some time. ${ }^{138}$

\footnotetext{
${ }^{138}$ Flight Lieutenant W. J. Lewis quoted in Kirby, Avro Manchester, 72. Miller's Flying Log Book confirms that he was part of the Manchester L7322 piloted by Flt. Lt. Lewis on May 12th, 1941. R.C.A.F., Observer's and Air Gunner's Flying Log Book, Erle Miller, May 12 1941. Kirby's work involved interviewing surviving crew members from 207 Squadron. Miller was apparently contacted but had "no interest in reunions or the history." "New Information on the Loss of Manchester EM-W L730," Robert Kirby, accessed 29 July 2012, http://www.207squadron.rafinfo.org.uk/manchesters/manchesters_L7380ameland.htm.
} 
Between 14 May and 21 June $1941,{ }^{139}$ Miller and his fellow crew members flew 14 night-time test flights, at which time they practiced air gunnery, smoke screen tests and engine feathering tests. ${ }^{140}$ Miller also wrote home during this two week stint about his first possible daylight operation: "Red and I are both on daylight operations to-morrow morning. It's my first daylight trip and Red's first trip. I think we're after the boat German Bismark which sunk our largest destroyer Hood. I don't mind it a bit and Red seems O.K. My operational trips have all been night flips." ${ }^{141}$ According to Miller's log book, however, the daylight trip never materialized and a few days later he explained the outcome to his family : "my day light flip was cancelled to the fact that the Navy got the Bismark ship that sank our largest destroyer Hood before we were due to take off. It was a nice bit of revenge done in quick order." ${ }^{142}$

It was becoming clear by the summer of 1941 that Bomber Command was enjoying little strategic success against their naval targets. The dangers of the Atlantic, however, had receded as the strength of the Wehrmacht and Luftwaffe were now concentrated deep in Russia, which meant that Bomber Command was able to focus its sights on German city centres once more.

\footnotetext{
${ }^{139}$ This gap in operational sorties was the result of Wing Commander K Purdon Lewis's decisions to ground all aircraft until such a time as all the oil filters could be examined and all the viscosity valves from the engines could be removed. The Manchesters had been experiencing engine trouble, due to air mixing with the oil as it left the scavenge pump. This aeration led to a reduced oil-pressure, which caused the oil temperature to rise which ultimately air-locked the scavenge pumps. After close to a month of testing, modifications to the Manchester were complete. Miller's next operation was June $21^{\text {st }}$ against Boulogne, followed by another sortie three days later on 24 June 1941 that targeted Dusseldorf. As minor operations, neither attack suffered any RCAF losses and Miller and the crew of the Manchester $\mathrm{L} 7321$ unleashed a total of 12,000 lbs. on these two cities. A few nights later, Miller and crew were sent up and over Hamburg as part of a 28 aircraft sortie. Kirby, Avro Manchester, 74-80.

${ }^{140}$ Miller's flying log book indicates that he had previously trained in air gunnery, smoke screen tests and engine feathering tests for a total of 30.45 hours prior to May 1941.

${ }^{141}$ Erle Miller to Gladys Miller, 26 May 1941. The Bismarck and the Prinz Eugen were examples of the serious threats in the Atlantic.

${ }_{142}$ Erle Miller to Gladys Miller, 28 May 1941. The Bismarck was torpedoed and sunk just before 11:00 am on the 27th of May, 1941. In this note, Miller's choice of language demonstrates a clear personal identification with the larger Allied effort, which was central to his connection with his service status. (He did however mistake the HMS Hood for a destroyer, when it was actually a battlecruiser.) This Allied victory appeared on the second page of the Renfrew Mercury and announced: "The great German battleship Bismarck, which sank the British ship Hood on Saturday near Greenland was itself sunk by Royal Air Force planes from the plane-carrier Ark Royal at five o'clock this morning. The Bismarck was 500 feet long and carried 35 guns. The H.M.S Prince of Wales was shelling the Bismarck but the R.A.F which had been following the ship since Saturday finally got her." Renfrew Mercury, 29 May 1941.
} 
With aircraft that could now carry heavier explosives further, bombing of specific targets around the Ruhr were ordered, if possible, during the full moon, or 'bomber's moon' period of each month. ${ }^{143}$ On nights when the absence of moonlight made the bombing of specific targets difficult, the bombers were directed to attack the cities of Cologne, Dusseldorf and Duisburg. When the weather was unfavourable for raids on the Rhine city areas, distant targets were listed for general attack instead. ${ }^{144}$ This new directive would be in force for the remainder of the summer and well into autumn; it would see Miller through to his last operation on September 7 th, $1941 .^{145}$

The summer of 1941 witnessed an increase in the tonnage of bombs dropped during intensive operations on German targets. While this was due in part to the increased number of aircraft being flown for each sortie, it was also a result of the bigger bombs, 8,000 lb. and 12,000 lb., which were now being produced. ${ }^{146}$ Miller's first operational objective during this period was Hanover on the night of July 17, 1941. ${ }^{147}$ Engine trouble in the Hampden A.D 917 caused the crew of Flight Lieutenant Lewis, Sgt. McLeod (Navigator), Sgt. Kingston (Wireless Operator), and Sgt. Miller (Air Gunner) to miss their operational target and to unload their payload of 2,500

\footnotetext{
${ }^{143}$ The objective during these better visibility conditions was to destroy railway installations preventing war materiel from being moved to Germany's fighting fronts. Targets were chosen in accordance with the Western Air Plan which had been devised by the Air Ministry before the war. Targets were chosen based on the defence strategy, the need of alternative targets to suit the weather and moon cycles, and in accordance with the operational limitations of Bomber Command. Economic targets, such as Germany's oil supply and associated industries, were also carefully considered within this system. Charles Webster and Noble Frankland, The Strategic Air Offensive Against Germany, 1939-1945 (London: Her Majesty's Stationery Office, 1961), 284-289.

${ }^{144}$ These cities were Hamburg, Bremen, Hannover, Frankfurt, Mannheim and Stuttgart. Middlebrook. These cities were chosen because they were larger targets. Middlebrook, The Bomber Command War Diaries, 120.

${ }^{145}$ Erle Miller to Alexander Wilson, 1991.

146 This power was a direct result of the new "heavies" which were introduced with the Short Stirling in midFebruary 1941. Two weeks later the Avro Manchester entered service, and these new types of aircraft provided their crew with heavier and more diversified payloads, which were simultaneously being introduced. These aircraft proved to be problematic, as the engines (two Royles Royce Vulture engines) did not provide enough power. The Manchester was eventually modified to take four Merlin engines also built by RR or Hercules (there were only a few aircraft that had the Bristol engines) and was transformed into the Lancaster. Millberry, The Royal Canadian Air Force at War, 276.

${ }^{147}$ The Hampden was used from July to August 1941, during such a time as the Manchester was out of commission due to engine problems.
} 
lbs. on Lingen, $35 \mathrm{~km}$ east of Hanover. ${ }^{148}$ Perhaps it was because he was now 'crewed-up', Miller wrote home saying, "I rather like operational trips now."149 Similarly, Flight Lieutenant Duffy wrote to his parents on this very matter in March of 1942, stating, "I'm captain of a crew and they're all good chaps, and we all get along swell, which is vitally important for our own safety."150 Camaraderie and trust was important for a crew, especially as the dangers and risk of flying operations became apparent as aircrafts and crews failed to return from flights over enemy territory.

Working and living in such close proximity intensified the friendships between airmen, which were important sources of companionship for men in service, away from friends and loved ones. But the perils associated with Bomber Command service meant that often these new friendships were short lived. Miller experienced this type of loss several months into his active service when his best friend overseas, 'Red' Maville, was shot down. ${ }^{151}$ It was a difficult loss for Dusty, as Red's death was caused by an Allied error in aircraft identification.

\footnotetext{
${ }^{148}$ The full moon for the month of July, 1941 was on the 8th. The main objectives for that night for 75 RAF aircraft was Cologne. The city of Cologne reported that only 68 bombs of all types were dropped causing no serious damage and no casualties. Middlebrook, The Bomber Command War Diaries, 177.

${ }^{149}$ Erle Miller to Gladys Miller, 18 July 1941 . Aircrews were put together in a rather ad hoc manner. As there was no formal assignment process, crews were formed largely by picking and choosing amongst themselves. During training, friendships would develop as pilots, gunners, navigators and aimers practiced and learnt along side one another. Over the course of training, and station and social life, groups would begin to form up based on these relationships and the informal assessments airmen made of each other's skills and personality; the end result was a crew that, for the most part, had a common bond. "Note on Crewing Up," Sheila Bryne, accessed 18 July 2012, http://www.214squadron.org.uk/Crews_and_losses.htm.

${ }^{150}$ Warren Duffy to Mr. \& Mrs. Duffy, 15 March 1942.

${ }^{151}$ The following quote is taken from Robert Kirby's Avro Manchester: The Legend Behind the Lancaster, and summarizes the unfortunate events surrounding this young airman's death: "No. 10 Group, Fighter Command, had scrambled a number of night fighters, including aircraft interception radar equipped Bristol Beaufighters from 25 Squadron, to counter the threat posed by the German intruders. The controller at 10 Group was honing one of the Beaufighters along the presumed track of the intruder and when the two tracks closed the Beaufighter was mistakenly honed onto the track of L7314. It appeared that in addition to this mischance another was to contribute to the events of the next few minutes. The 5 Group operations plan for that night, giving times and routes etc. had gone via Bomber Command to Fighter Command, arriving at 10 Group just at the time of the change of controllers. The new controlled had received the operations plan, but it had become covered by other papers on his desk and the details within it had not therefore been extracted and placed on the operations board. Consequently he had no information before him to indicate the presence of friendly aircraft at the vital location. Accordingly, the controller homed the Beaufighter onto the 'hostile' until the pilot was able to obtain a visual on the aircraft ahead in the
} 
In his first letter home about his friend's death, Miller wrote very little about this loss, and what he did share contained no account of the event itself: "Everything going pretty good here. I'm a bit lonely without Red but I still have Firtz my Swizz girl friend. [...] I just finished writing a letter to Mrs. R Maville Dalhousie Station here about Red's death. Guess that will be quite a blow. I also phoned his girl friend in town but couldn't make connections. Sure is tough." 152 Over the coming weeks, Miller continued to mention his friend in the letters he sent home to Castleford, sharing, "Miss Red a bit as we always went on leave together but I'm managing to have a pretty good time by myself." ${ }^{153} \mathrm{He}$ continued to grieve for his friend through the remainder of his active service, and, as the number of sorties that Miller completed increased, one can only surmise that his friend's death served as a constant reminder of how abruptly his own war could end.

darkness. Squadron personnel believe that what happened next was that the Beaufighter pilot identified the aircraft as an RAF bomber and replayed this to the controller. The controller was unwilling to accept this identification. Cautiously the Beaufighter moved closer, recognising roundel markings and RAF squadron codes in plate letters on the fuselage. Clearly the bomber crew had also seen the Beaufighter for they fired off the correct colours of the day. This was passed to the ground station, where the controller still insisted the aircraft to be hostile and instructed the pilot to complete the interception and shoot the aircraft down. Although in two minds, the Beaufighter pilot dropped back before finally closing in again and giving the Manchester, still flying slowly and straight and level, a burst with the fixed forward cannon and machine guns. The Manchester was fatally hit and plunged to the ground at Wollaston, Northamptonshire, at 0155 hours. If not killed by the fire from the Beaufighter, the crew must have died instantly in the crash. The wreckage burnt fiercely and part of the bomb load exploded. Next day only traces of five separate bodies and the identity disc of Sergeant James, the second pilot, could be found in the burnt wreckage. It was a tragic mistake which should never have happened and for which safeguards were in operation, yet under the stress of war such human errors were likely. Flying Officer Withers and crew had had only about 20 minutes of operational flying experience before being so brutally and mistakenly cut down." Kirby, Avro Manchester, 79. Red was killed on June 22nd, 1941 and is buried at Lincoln (Newport) Cemetery. "Casualty Details," Commonwealth War Graves Commission, accessed 15 July 2012, http://www.cwgc.org/search-for-war-

dead/casualty/2358645/MAVILLE,\%20JOHN\%20ALLAN.

${ }^{152}$ Erle Miller to Gladys Miller, 23 June 1941.

${ }^{153}$ Erle Miller to Gladys Miller, 5 July 1941. Miller mentioned Red's name in nine letters between late June to early August, 1941.The last letter read: "About clothes Mom, I've plenty. Lots socks underwear 3 heavies and lots of shorts, shirt and shows. Fact is I'm pretty well fixed in wearing apparel. You see I have some of Red's kit which he more or less willed to me. I'll tell you what I will need later on but not for some time. Is black pair of leather gloves for dress-up. You can't buy them over here. Last winter Red and I tried in London and also in Glasgow and couldn't buy a pair." Erle Miller to Gladys Miller, 5 August 1941. 
Miller was part of the first operation against Frankfurt on the 21 of July $1941 .{ }^{154}$ While his crew unloaded 2,500 lbs. as part of a 71 aircraft assault, Frankfurt did not record this as a significant raid and reported only 'bomb explosions' in its official documentation. ${ }^{155}$ Darmstadt, a town 15 miles away, however, was left with 15 buildings hit and 16 people killed. ${ }^{156}$ Having been over Karlushe during the early morning hours of August 5th, Miller wrote: "was on Ops. last night and boy did we give them the works. You could see the fire that was caused from the bombs for 100 miles. The whole town was practically on fire." ${ }^{, 157}$ In that same letter Miller included, "I'm on again to-night but tis not in Hampden Bomber but the Big Manchester Bomber. They carry a real big bomb load and go like hell." ${ }^{\text {"158 }}$ While it was true that the crew of L 7422 would unload their largest payload to date, a staggering 5,000 lbs., the most serious incident of that night was the destruction of a bakery. ${ }^{159}$ Sgt. Miller would continue to fly in Manchesters for the remainder of his operations with Bomber Command. ${ }^{160}$

During the night of 7 August 1941, Miller and the crew of L7422 dropped a payload of 6,000 lbs. on the German capital. ${ }^{161}$ While Miller had previously written a disgruntled note home that, "we were supposed to have been on OPs to-night but it was scrubbed. I think it might have been Berlin and that's the spot I like bombing," this in fact was the young serviceman's first

\footnotetext{
${ }^{154}$ R.C.A.F. Observer's and Air Gunner's Flying Log Book, Erle Miller, 21 June 1941.

${ }^{155}$ R.C.A.F. Observer's and Air Gunner's Flying Log Book, Erle Miller, 21 June 1941. As the late summer of 1941 approached, the bomber offensive was in shambles due to its ineffectiveness, but this reality did not present itself in Miller's correspondence home or in the Renfrew Mercury. The sustained bomber attacks did not affect the Germans either, as it was later established that they were not aware of Bomber Command attempts to attack their oil industry. McCaffery, Battlefields in the Air, 43.

${ }^{156}$ Middlebrook, The Bomber Command War Diaries, 119.

${ }^{157}$ Miller had been part of a 97 aircraft attack on Karlsruhe's railway stations and lines that resulted in the death of 34 civilians and severe bombing in the Rhine Harbour and in the Weststadt and Muhlberg areas.

${ }^{158}$ Erle Miller to Gladys Miller, 5 August 1941. Miller and crew flew one operation in AD 917 Hampden and three in AE 247 Hampden, between July 14th, and August 5th, 1941. R.C.A.F. Observer's and Air Gunner's Flying Log Book, Erle Miller, July to August 1941.

${ }^{159}$ Middlebrook, The Bomber Command War Diaries, 201 1, 210.

${ }^{160}$ R.C.A.F. Observer's and Air Gunner's Flying Log Book, Erle Miller, July to August 1941.

${ }^{161}$ R.C.A.F. Observer's and Air Gunner's Flying Log Book, Erle Miller, 7 August 1941.
} 
sortie over Berlin. ${ }^{162}$ This reference, therefore, reflects Miller sense of participation in the collective effort, and preoccupation, with taking Berlin.

Robert Kirby's work, Avro Manchester, contains in depth coverage of the operations flown by the 207 Squadron during the Second World War. Within this larger analysis, this text offers unparalleled insight into Miller's active service with the RAF, as it traces Miller's last sortie during the Second World War up until the moment of his capture. By examining this publication, alongside the Miller Collection, it is evident that Miller's recollection of his experience is not in keeping with the established account this event. Kirby's work, in blending oral interviews and official histories, presents circumstances and outcomes which either do not appear or are incorrectly described in his personal correspondence and logbook. On the night of 7 September 1941, Sgt. Miller's last operation targeted Berlin. ${ }^{163}$ Miller's pilot, Flt. Lt. Lewis, was particularly eager to get in the air that night, and, once there, he directed the aircraft for 'The Gate' near Skegness; his usual exit point when crossing the English coast and heading for Europe. ${ }^{164}$ In order to avoid the searchlight belt in Holland and the flak defences of the Ruhr valley, Lewis took a flight path across the North Sea which brought the crew of the L7380 to the German coast, north of the River Elbe. From there, he intended to change course and head south east to Berlin. ${ }^{165}$

\footnotetext{
${ }^{162}$ Erle Miller to Gladys Miller, 3 August 1941.

163197 aircraft were sent to Berlin that night - 103 Wellingtons, 43 Hampdens, 31 Whitleys, 10 Stirlings, 6 Halifaxes, 4 Manchesters. "Good bombing" was claimed by 137 crews in clear visibility. "Berlin reports most bombs in the Lichtenberg and Pankow districts, which are east and north of the centre. Damage was reported at 4 war-industry factories, 10 transport and 13 public utilities, 2 public buildings, 1 zoo, 16 farms and 200 homes. In total, 36 people were killed, 212 injured and 2,873 were bombed out." Middlebrook, The Bomber Command War Diaries, 200-201

${ }^{164}$ The information that follows, unless stated otherwise, can be found in Kirby, Avro Manchester, 98-102.

${ }^{165}$ It was Lewis's intention to remain at a height of 8,000ft until his craft was within striking distance of the German coast. By this point, the plane would have burned off almost two hours worth of fuel, which Lewis hoped, would make it light enough to be able to climb to perhaps $14-15,000 \mathrm{ft}$ without the engine overheating. Ibid.,98.
} 
The outward flight to the German coast was uneventful for the crew of L7380. Having picked up a strong tail wind, they reached the enemy coast line sooner than anticipated, and Lewis began his climb to an altitude of approximately $13,000 \mathrm{ft}$, which he attained over Tonning in Schleswig, Holstein. ${ }^{166}$ Two hours into their sortie, Sgt. Miller spotted a German Messerschmitt coming out of the dark night clouds and called out to the crew, "night fighter astern!"167 What followed, was, as Miller put it, "a merry fight of it," as the Allied aircraft was first hit with a burst of machine gun and cannon fire. ${ }^{168}$ The initial enemy fire hit the port wing by the port engine, and, with the low speed that Lewis was flying, there was no possibility of evasive action. Instead, he forced the plane into a dive and no sooner was this action initiated than a second burst of machine gun and cannon fire ripped across the plane. ${ }^{169}$ Miller opened fire on the Messerschmitt Me110 and forced him up into the mid-upper gunner's field of fire. ${ }^{170}$ Miller fired once more in the general direction of the fighter before it broke away and lost contact completely. ${ }^{171}$ Recalling the event some 50 years later, Miller noted that, "the tail gunner with his 4 brownie machine gun shot down the fighter," however there was no record of the night fighter concerned, nor whether any damage was inflicted by the return fire. ${ }^{172}$

While the gunners, Miller included, kept a sharp lookout, Lewis took stock of the situation. The pilot could vaguely discern the many hits that the aircraft had sustained along its port wing and engine; all the engine functions appeared normal, but the fuel gauges indicated a serious leak in the port fuel tank. Lewis quickly concluded that they would not make it to Berlin, and so he

\footnotetext{
${ }^{166}$ Ibid., 98.

${ }^{167}$ Ibid., 99.

${ }^{168}$ Erle Miller to Alexander Wilson, 1991.

${ }^{169}$ Ibid., 98.

${ }^{170}$ Kirby, Avro Manchester, 98.

${ }^{171}$ Ibid., 98.

${ }^{172}$ Erle Miller to Alexander Wilson, 1991. In Miller's description of the operational sortie to his grandson, he incorrectly labeled the mid-gunner as "tail gunner." Miller, as both his flying log book and Kirby's text indicate, was in fact the 'tail-end Charlie'.
} 
accordingly diverted the plane south to Wilhemshaven, where they were able to drop the $4,000 \mathrm{lb}$ payload. ${ }^{173}$ Relieved of the bombs and part of the fuel load, and supported by the denser air at the low level, Lewis was determined to make an all out effort to return to safe ground.

As the crippled aircraft headed for home, gradually they descended into the cloud tops and down through the cloud layer on instruments until they eventually emerged to see the dark waters of the North Sea beneath them. The Manchester, according to Miller, kept "gradually getting lower and lower until it got too low to bail out."174 Miller, having misunderstood the initial instructions to take up crash landing positions, thought that the plane was about to crash, and opened the rear side entry door and made to jump out. The mid-upper gunner, in climbing down from the turret to take up crash position, had just enough time to grab Miller, pull him back, and slam the door. The crew crashed 5 miles out into the North Sea just after midnight on the 8th of September. Miller, unable to settle into the proper crash position, was thrown violently forwards with the crash, and broke a small bone in his right hand. Suffering from this injury, Miller clambered into the aircraft's rubber dingy and the crew proceeded to paddle to shore. ${ }^{175}$

Once on land, the crew started walking along the beach, and quickly established their location as an island. Shortly thereafter, they found a larger lifeboat at least $25 \mathrm{ft}$ long with a mast, engine, and fuel. After scavenging boards and poles, the crew tried to lever the boat seawards in hopes of sailing it away. They worked tirelessly throughout the night, but were unable to move the vessel. ${ }^{176}$

\footnotetext{
${ }^{173}$ A radio message was transmitted saying they had been attacked by a night fighter and were returning to base. Somehow during this transmission, the message had become garbled, and squadron was left with the impression that the attack had taken place 50 miles from Berlin, when in reality they had barely crossed the coast. Ibid, 99.

${ }_{174}^{174}$ Erle Miller to Alexander Wilson, 1991.

175 Kirby, Avro Manchester, 100.

176 Ibid., 101.
} 
At about 9:00 a.m., a German soldier appeared just over the dunes and, raising his rifle, shouted to Miller and crew to raise their arms. He called out to others, and "a big car pulled up and six Gestapo Germans jumped out with revolvers pointing at us. The only English they knew was: 'FOR YOU THE WAR IS OVER.",'177

${ }^{177}$ Erle Miller to Alexander Wilson, 1991. Miller's Flying Log Book states, "aircraft failed to return. Attacked by 110. Dropped load on Borkum Island, Objective Berlin, Forced Landing on Island Ameland." R.C.A.F. Observer's and Air Gunner's Flying Log Book, Erle Miller, September 7 1941. Nearly $60 \%$ of Bomber Command aircrew became casualties. Roughly $80 \%$ of the casualties were suffered on operations and $15 \%$ during training or on other related accidents. On 31 May 1947, the Air Ministry released the following statistical breakdown of these casualty figures: 47,268 killed in action or died while prisoner of war; 8,195 killed in flying or ground accidents; 37 killed in ground-battle accidents. Middlebrook, The Bomber Command War Diaries, 190. 


\section{Chapter Two: Prisoner of War}

There exists an enduring popular cultural myth about the Allied prisoner of war experience of the Second World War which sees the British and Commonwealth master narrative as centered, almost entirely, on the place of escape in the lives of the captive. ${ }^{178}$ This overarching emphasis on escape, which was less pervasive than commonly assumed (there are only thirty documented escapes of Allied POWs to England and neutral countries from German administered camps from 1939 to 1945), has meant that other aspects of POW life, such as camp operation, daily routines and leisure activities, have been significantly underrepresented in the associated scholarship. ${ }^{179}$

In a limited way, the Miller Collection does echo this narrative as Miller's first POW journal, from January to December 1942, contains four entries which refer to escape attempts. ${ }^{180}$ One, written on 17 May 1942 when Miller was in Stalag Luft III, reads: "Boys caught making tunnel thru the privy house." 181 Just over a month later Miller noted the misfortunes that

\footnotetext{
${ }^{178}$ According to S.P. Mackenzie, author of The Colditz Myth, "the popular image of what went on at Colditz castle, and by extension what happened at more anonymous camps elsewhere in the Greater Reich in more diluted form, became and remained one in which prisoners bore the burden of captivity with a light heart while helping one another with schemes to outwit and ultimately evade their captors." S.P. Mackenzie, The Colditz Myth: The Real Story of POW Life in Nazi Germany (Oxford: Oxford University Press, 2006), 2. This understanding is reinforced by best-selling books, popular films, television drama series and TV documentaries such as The Colditz Story (1955), Colditz (1972) and Hogan's Heroes (1965).

${ }^{179}$ For an introduction to the extensive literature on escape in Allied prisoner of war camps during the Second World War, see Aidan Crawly, Escape from Germany: The Methods of Escape Used by RAF Airmen during the Second World War (London: HMSO, 1985); Alan Burgess, The Longest Tunnel: The True Story of World War II's Great Escape (London: Bloomsbury Publishing, 1990); Ian Dear, Escape and Evasion: POW Breakouts in World War Two (London: Cassell, 2000); Jonathan Vance, A Gallant Company: The Men of the Great Escape (Pacifica, Cal.: Pacifica Press, 2001), and R.T. Bickers, Home Run: Great RAF Escapes of the Second World War (London: Leo Cooper, 1992).

${ }^{180}$ The RCAF's monthly publication, the Roundel focuses on Stalag Luft III across seven of its issues in 1949/50. In April 1950, for example, the issue contains Flt. Lt. Mahoney's memoir of the March 1944 escape attempt from Stalag Luft III, wherein he discusses the layout, sand dispersal, and the eventual failure of his attempt to escape from behind barbed wire. Flt. Lt. John Mahoney, "Stalag Luft III: Part 6," Roundel 2 (April 1950): 9-11.

${ }^{181}$ Miller, POW Journal, v.1, 17 May 1942. EMC. This journal, which dates from January to December 1941, covers all of Miller's incarceration at Stalag VIIIB, and seven months of his captivity at Stalag Luft III.
} 
accompanied one failed escape attempt: "4 officers escaped this morning. Heard one was shot."182 Most of the Miller Collection, however, is not in keeping with this focus as Miller's letters and two POW journals provide greater insight into the methods for coping with a life of captivity, as well as an appreciation into everyday experiences and routines behind barbed wire.

Moving beyond the focus on physical escape, the Miller Collection's 117 letters and two prisoner of war journals present Miller's marked efforts at mental escape from behind the barbed wire of five POW camps. ${ }^{183}$ His experiences at these camps were markedly different, as three of the camps were army run camps, and two were administered by the Luftwaffe, expressly for airmen, and provided better overall treatment of internees. But even in these latter camps, everyday life was still very difficult and the Miller Collection highlights Miller's continued efforts to engage both his time and imagination in leisure activities in order to find some relief from this monotonous routine.

Miller entered his first permanent camp, Stalag VIIIB, in late September 1941, and remained there for over six months until 14 May 1942. His letters and journal reveal that, during this period, he was emotionally vulnerable and his physical health had deteriorated considerably since his capture. Gradually, however, Miller was able to regain his emotional strength by seeking support from fellow internees. ${ }^{184}$ After transferring to the air force camps, Stalag Luft III and later Stalag Luft VI, where he was to spend a total of 27 months, Miller's correspondence

\footnotetext{
${ }^{182}$ Miller, POW Journal, v.1, 23 June 1942.

${ }^{183}$ Miller's four plus years as a prisoner of war began at Stalag VIIIB, an army camp located in Upper Silesia. On 14 May 1942, Miller was moved again to Stalag Luft III, also in Silesia, which was reserved solely for air force prisoners. He was moved yet again on 16 June 1943 to Stalag Luft VI on the border of Lithuania and East Prussia. To escape the advancing Soviet Armies, the German prison authorities transferred Miller on 17 July 1944 to Stalag VIK in Thorn, Poland. In early August 1944, Sgt. Miller was one of 3,000 prisoners of war who were moved deeper into Germany to avoid advancing armies. This last camp, called Stalag XIB at Fallingbostel, was near the Elbe River. Miller's first journal from his time as a prisoner of war covers January to December 1942. The second journal begins in August 1944 and runs until 5 June 1945.

${ }_{184}$ On 21 November 1941, Miller's wrote his mother a note that contained a reference to his friends and other forms of comfort at Stalag VIIIB: "Everything is going fine here. I'm quite comfortable and in good health.[...] I'm with my friends.[...]On the whole we're not badly off." Erle Miller to Gladys Miller, 21 November 1941.
} 
and journal reveal a noticeable improvement in his ability to cope independently with his captivity. ${ }^{185}$ While familiarity with his surroundings and an acceptance of his POW status were key factors in this personal change, the improved conditions afforded by air force camps, in comparison with what he had previously experienced, notably at the army camp Stalag VIIIB, undoubtedly helped Miller endure his internment. ${ }^{186}$

The situation in all camps depended heavily on the personality of their commandants, as it was they who set the standard as to how prisoners should be treated. ${ }^{187}$ As an imprisoned Allied airman and NCO, Miller was doubly more fortunate than his fellow captives from other forces, national backgrounds and lower ranks. ${ }^{188}$ As a Commonwealth airman Miller's worth as a captive was interpreted as high by German officials who imposed a hierarchy of treatment on their prisoners. ${ }^{189}$ Eventually, however, this system was crippled by inefficiency as Germany could not build prisoner of war camps quickly enough to accommodate the increase in the number of captured Allied servicemen, which negatively affected internees later in the war. Life

\footnotetext{
${ }^{185}$ Miller was incarcerated at these two camps from 14 May 1942 until 17 July 1944 . The Wehrmacht camps were called Stalag or permanent camp, the Luftwaffe camps were labeled Stalag Luft and the navy camp was called Marlag und Milag Nord. In October 1939, Germany had 31 POW camps, a figure that reached 248 by the end of the war. Adrian Gilbert, POW: Allied Prisoners in Europe, 1939-1945 (Great Britain: John Murray, 2006 ), 66.

${ }^{186}$ The Luftwaffe prided itself on treating prisoners better than the army, and the commandants from Stalag Luft I (Barth), Stalag Luft III (Sagan) and Stalag Luft VI (Heydelrug) were praised after the war. Giles Romilly and Michael Alexander, The Privileged Nightmare (London: Pan Books Limited, 1965), 84-85.

${ }^{187}$ The system was designed to be efficient and straightforward, but in practice was quite complicated with the German high command giving each of the armed services responsibility over their own prisoners: the Wehrmacht processed all army prisoners; the Luftwaffe looked after all air force captives; and the Kreigsmarine handled navy personnel. The Germans also had a policy of segregating officers and non-commissioned officers (NCOs) into separate camps and this division allowed for different conditions and accommodations. For instance, in accordance with the Geneva Convention of 1929 , officers and NCOs were granted exemption from manual labour. Exemption, however, was a mixed blessing as those who engaged in agricultural work had greater freedom than those that remained at base camp, and, often, they were able to supplement their diet through trade with the local population. Work, for some, also had therapeutic benefits and could be far less demoralizing than long periods of confinement behind the camp wire.

${ }^{188}$ Under the Geneva Convention, those with a commission, as well as many non-commissioned officers, were exempt from the provision that prisoners could be compelled to engage in non-war-related work by the detaining power while in captivity. Mackenzie, The Colditz Myth, 193.

${ }_{89}$ As a Flight Sergeant, Miller did not have access to Offizierlager, prisoner of war camps for officers, but like those holding commissions he was not required to perform compulsory labour tasks. For more information on rank and privilege, see Joan Beaumont, "Rank, Privilege and Prisoners of War," War and Society 1 (1983): 67-94.
} 
inside the camps, therefore, was very much subject to the vagaries of war and conditions changed with every passing week, month and year. Miller became a POW at an early stage of the conflict, when German camps were well under capacity and supplies were plentiful enough to discourage racketeering. ${ }^{190}$ Accordingly, captives like Miller experienced a patchwork system of authority which fostered different prisoner experiences based on service, rank and length of imprisonment.

After being taken into custody by the Gestapo in the early morning hours of 8 September 1941, Miller and the crew of the downed L7380 Manchester were brought to the German Durchgangslager der Luftwaffe camp at Oberusal, the central German Air Force Interrogation Centre. ${ }^{191}$ Unfortunately, it is not known how Miller arrived at this transit camp, but the Luftwaffe traditionally transferred airmen as quickly as possible by road or via the rail network to Dulag Luft. ${ }^{192}$ This efficiency was connected to the valued intelligence that could be garnered by interrogating air force personnel, as airmen could supply useful information on day-to-day conditions in Britain, as well as material which could assist in the defense of German factories and towns against RAF bombers. ${ }^{193}$ Given their high level of technical and operational

\footnotetext{
190 Jonathan Vance, ed. Encyclopedia of Prisoners of War and Internment (Santa Barbara: ABC-CLIO, Inc., 2000), 119.

${ }^{191}$ This camp's title was commonly abbreviated to Dulag Luft. The main part of the camp consisted of four large wooden barracks, two of which were connected by a passage. These contained some 200 cells which were eight feet high, feet wide and twelve feet long, held a cot, a table, a chair and an electric bell for POWs to call the guard. The third barrack contained administrative headquarters. The fourth building, a large $\mathrm{L}$-shaped structure, housed the interrogating offices, files and records. Senior officers lived on the post; junior officers outside in a hotel. The commandant lived on nearby farm. The entire camp was surrounded by a barbed-wire fence, but was equipped with neither perimeter floodlights nor watchtowers. "Dulag Luft," Military Intelligence Service War Department (1945), accessed 8 July 2012, http://www.b24.net/pow/dulag.htm.

${ }_{192}$ The camp expanded in 1941 to include Auswertestelle West, or Evaluation Centre West, as a result of the increasing numbers of captured airmen. At its opening, Auswertestelle West consisted of 129 solitary confinement cells but grew, over the course of the next year, to about 200 cells, many of which were equipped with electronic listening devices. In September 1943, this facility was moved to a public park in Frankfurt. It remained at this location until March of 1944, when it was destroyed by Allied bombs. Vance, Encyclopedia of Prisoners of War and Internment, 77.

${ }_{193}$ Charles Rollings, Prisoner of War: Voices from Behind the Wire in the Second World War (London: Random House, 2008), 54.
} 
knowledge, and the fact that airmen were most often captured in small numbers, interrogation was both feasible and desirable. All those that passed through Auswertestelle West, for example, were interviewed by skilled Luftwaffe interrogators who employed a variety of techniques in their attempts to entrap and coerce demoralized Allied airmen into divulging information. ${ }^{194}$ Solitary confinement, for example, was an established part of the interrogation procedure at Dulag Luft, and Miller spent 10 of his 19 days there in a sparsely furnished cell "on a diet of bread and water and no cigarettes." 195 Every prisoner was then confronted with a wide variety of questions, many of which were of a military nature. ${ }^{196}$ In order to pressure airmen into completing this form, prisoners were told that a failure to do so would result in a significant delay in informing their next of kin of their whereabouts. ${ }^{197}$ Airmen were also taken into interview rooms for formal questioning. Here, interrogators might use American and British goods, such as cigarettes, cigars and even beer, to 'soften up' their subjects. ${ }^{198}$ They would also show their captives thick files that allegedly contained information on their squadron; this technique was used on new prisoners in the hope that it would convince them that their captors knew everything about them and their unit and that there was, therefore, no real harm in

\footnotetext{
${ }^{194}$ Vasilis Vourkoutiotis, "What the Angels Saw: Red Cross and Protecting Power Visits to Anglo-American POWs, 1939-45," Journal of Contemporary History 40 (2005): 11-12.

${ }^{195}$ Erle Miller, Brockville, Ontario to Alexander Wilson, St. Catharines, Ontario, (no calendar day given) 1991. The cells themselves were virtually devoid of washing stations, and consisted of a bed, a radiator and two blankets. Fl/Lt Wilkie Wanless of 76 Squadron RAF also experienced a "dinky, ungodly uncomfortable cell." "Learning by Experience," Wilkie Wanless, accessed 7 July 2012, www.rafbombercommand.com/personals_2_dangersofwar.html.

${ }^{196}$ Internees were also required to fill out a registration report which, under Article 28 of the Geneva Convention of 1929, enabled the camp's administration to provide the ICRC with a list of Allied captives; it was then the ICRC's responsibility to inform the next-of-kin of the status of their interned family member(s). The Miller Collection, unfortunately, does not include his report from Dulag Luft. For an example of this report see George Hill Collection,"Prisoner of War Index Card", [58A 1 232.3] Canadian War Museum, Ottawa, Ontario. This form labeled "kriegsgefangenekartel," or prisoner of war card, included two small photographs, thumb-prints and very basic biographical information about each POW.

197 Vance, Encyclopedia of Prisoners of War and Internment, 78.

198 Albert Clark. 33 Months as a POW in Stalag Luft III: A World War II Airman Tells His Story (Colorado: Fulcrum Publishing, 2004), 34. For insight into tactics and approaches to interrogation procedures, see Hanns Scharff and Raymond Toliver's The Interrogator: The Story of Hanns Scharff, Luftwaffe's Master Interrogator (Fallbrook, California: Aero Publishers, 1978).
} 
answering any questions. ${ }^{199}$ A further ruse involved RAF airmen who were blackmailed or otherwise manipulated by their captors, or Germans posing as RAF personnel, to solicit information when a prisoner's guard might be down. ${ }^{200}$ If these interrogation strategies failed, prisoners could be denied access to the toilet for hours on end, wounds that were not lifethreatening might not be tended to immediately, or the heat in the cells could be turned up or down in order to increase physical discomfort. No matter how tough the interrogations were at Dulag Luft, however, they remained broadly within the framework of the Geneva Convention and most aircrew passing through this transit camp remained physically unscathed. ${ }^{201}$

As Miller experienced a drastic change in his status from combatant to prisoner, there was a significant delay in communication with family as the post system lagged in the redirection of his mail. The Miller Collection contains one letter which highlights the confusion often associated with wartime communication: it is a note dated 6 September 1941 from Gladys Miller which never reached Erle Miller. The envelope of this particular letter captures the chaos of the postage system's efforts to follow Miller's change in status and location. The face of the envelope is covered with writing in pencil and ink, stamping marks and subsequent scribbled attempts to cover previous addresses. What stands out most through this inscribed confusion, however, is a red stamp that simply reads: "Reported as Missing."202 Addressed to "Sgt. Miller Erle Sinclair, 400th Squadron R.C.A.F, Canadian Army Overseas," the envelope, and its

\footnotetext{
${ }^{199}$ Warrant Officer Ross Elford, 35 Squadron RAF, recalled his interrogation experience, stating "I wouldn't give him any information, so he finally said to me, "Here, have a look at your squadron." Tossed this book on the desk, and it had our squadron crest on the front of it. I looked in the book and it had everybody's name and squadron leaders. He had our pilot's name, and our crew. Had aerial photographs of the squadron. I couldn't contribute much to their book. Their intelligence was fantastic." Daniel Dancocks, In Enemy Hand: Canadian Prisoners of War 1935-1945 (Edmonton: Hurtig Publishers, 1983), 61.

${ }^{200}$ Charles Rollings, "Dulag Luft," After the Battle 106 (1999): 22.

${ }^{201}$ Section 1 of Part III of the Convention which dealt with captivity stated that the detaining powers may use "no physical or mental torture, nor any other form of coercion." Vance, Encyclopedia of Prisoners of War and Internment, 108-109.

${ }^{202}$ Envelope from correspondence: Gladys Miller to Erle Miller, 6 September 1941.
} 
contents, were redirected back to the base post office in Canada, and from there, back to Erle's mother in Castleford. ${ }^{203}$ While Gladys's presence is felt throughout the Miller Collection, this is the only letter, of the 297 , which was written by her. This alone makes it a rare piece, as it provides a moving insight into the maternal comfort that Miller received from his mother and something of her sorrowful experience of the war. The poignancy of its message is heightened by the knowledge that the letter was sent one day before Miller's last sortie:

I must write you a line tonite but I have only one thought uppermost in my mind and it's hard to write. You remember me telling you so much of Pilot Officer Brian McCallum being here, he was quite friends with Marg - went to see her several times when at Trenton. He was transferred back to Calgary as instructor, well his plane crash on Fri. and he was killed. He was the same age as you Erle. You were Christened or Baptised on the same day at his home in Alberta. Brian was a swell kid, such a bright smart lad, and his father died suddenly last winter. He has another brother in the force too. [...] I have just finished writing Margaret to tell her about Brian she'll feel dreadful I know, as she was quite fond of him and he wrote her every week. He wanted so badly to go overseas and his mother was so pleased when he was left here. So one never knows. Oh! Erle son I wish it was all over and you were safely home dear. I am a big sissy I know but I get so lonely at times and this happens to be one of them. [...] It was a year yesterday Sept. 6th since you landed over there. [...] Be my own good son Erle. Write often. Don't forget to say your prayers and remember you are always in our thoughts. ${ }^{204}$

On 7 September 1941, Gladys Miller's fears became her son's reality.

Miller was eager to contact his family and reassure them that he was alright. Four days after the crew's capture he sent home his first letter from behind barbed wire: ${ }^{205}$

\footnotetext{
${ }^{203}$ Ibid.

${ }^{204}$ Gladys Miller to Erle Miller, 6 September 1941. According to the Canadian War Graves Commission, Brian McCallum died on 4 September 1941. "Search for War Dead," CWGC, accessed 8 July 2012, http://www.cwgc.org/find-war-dead/casualty/2850205/McCALLUM,\%20BRIAN\%20ALLAN.

${ }^{205}$ This is an especially important letter in the Miller Collection as it is the first letter Gladys received from her son and marked an end to a worrying hiatus in communication. At this relatively early period in the war, the International Committee of the Red Cross (ICRC) was able to facilitate correspondence between POWs and the
} 
I am fine except for a slightly sprained wrist. ${ }^{206}$ The camp is fairly comfortable as prison camps go. Please send regulation air force shirts and shoes similar to those sent before, cigarettes and tooth brush etc Contact Red Cross for address and regulations. You can also send parcels thru the American Red Cross. All our crew are safe and we are treated quite well. We do no work and the quarters \& food are ok. If you contact the tobacco company there is probably some arrangement for sending cigarettes. I understand you can send a $10 \mathrm{lb}$. weight of parcel thru Red Cross. You can inquire into this. There is really very little I can tell you except I am in good health and well treated. I can receive all the letters you can send write daily. I will be home when the war is over so do not worry. ${ }^{207}$

Miller's remark on the standard of comfort provided by the camp was insightful, regardless of his limited exposure to prison life. ${ }^{208}$ The inspectors from the International Committee of the Red Cross generally rated the conditions of the Dulag and Stalag Lufts as 'good' or 'excellent', in comparison with Stalags which were deemed to be of 'deficient' and 'wholly inadequate' conditions. ${ }^{209}$ Dulag Luft, in particular, was a camp that adhered to a particularly high standard of care for its transient captives, as the Germans' believed that prisoners who were well treated in the first few days of their internment might let their guard down and reveal useful military intelligence to their captors. ${ }^{210}$ In spite of these efforts, Miller's

home front. As the war progressed, and with the mounting Bomber Command raids, the ICRC and camp administrators were unable to keep up with the volume of letters sent from behind barbed wire. This had a decidedly negative impact on the connection between the home front and captives. In Miller's case it was several weeks before his family were made aware of his POW status, and several months before correspondence assumed some relative normality for the Millers.

${ }^{206}$ While Miller sprained his wrist during the $\mathrm{L} 7380$ Manchester crash, he did not spend any time at the hospital at Hohemark. Robert Kirby, Avro Manchester, 100. As a rule, men needing medical assistance were sent to Hohemark hospital, but only about half of those suffering from minor wounds received treatment. "Dulag Luft," Military Intelligence Service War Department (1945), accessed 8 July 2012, http://www.b24.net/pow/dulag.htm.

${ }^{207}$ Erle Miller to Gladys Miller, 12 September 1941. Erle ended 32 of the 117 letters he sent home during his imprisonment with sentiment.

${ }^{208}$ Erle Miller to Gladys Miller, 12 September 1941. Frederick Tisdall, "Final Report on the Canadian Red Cross Food Parcels for Prisoners-of-War," The Canadian Medical Association Journal (March 1949): 280.

${ }^{209}$ Vourkoutiotis, "What the Angels Saw," 9. The Geneva Convention of 1929 allowed the ICRC to have general access to the camps of both the Axis powers and the Allies. As a result of this access, hundreds of reports were written and subsequently categorized by time, the quality of material conditions, and incidents of violations of prisoners' rights under the Geneva Convention. The terminology used by the inspectors changed over the course of the war as the standards to which the inspectors held the detaining power accountable declined as the war continued. ${ }^{210}$ This 'standard of care' could not be verified in all prisoner of war camps as the ICRC was not granted access to prisoners of war from certain custodial states. An example of this can be seen through the ICRC's efforts to visit 
greatest sense of relief during his transition to prisoner of war came from the collective support he garnered from the companionship of his fellow crew members.

In his second and last letter from Dulag Luft, Erle drew the attention of his mother to the relative comfort that his crew, and their safety, afforded him. He sent the following note home on 17 September 1941, ten days after he had taken off on his last sortie from England:

Everything going not bad as a prisoner of war. Tell all my friends to send cigarettes through tobacco co's. I'm fairly comfortable with my chums. Could do with doeskin shirts. Heavy underwear, scarf, sweater, tooth brush, paste, send through Red Cross, cigarettes through tobacco co. I wrote a letter to accounts section referring home maximum amount so should be receiving over $60 \$$ a month $3 / 4$ of my pay. Flannel pygamas[sic] will be appreciated. There is no restriction on number of parcels the American Red Cross can send but there is on Canadian. Get in contact with them. I'm in good health but had a bit of tough luck. All my crew safe. I sprained my wrist which is my only wound. Was awfully lucky. All I can do is wait and hope this war finishes soon. Send lots cigs as they can be exchanged. Also any warm clothes. Don't worry as I'm fine and very lucky. ${ }^{211}$

By presenting the emotional solace provided by his 'chums,', alongside the physical luxuries available from home, such as warm clothes and basic toiletries, Miller was able to assure his family, as well as himself, of the relative normalcy of camp life. These relationships fostered a sense of place and locality for Miller. Here, more so than in his previous service experience, face-to-face relationships dominated his lived environment and informed his daily routine. By their very nature, they provided a sense of community within a foreign setting and ensured feelings of security, commitment and belonging. ${ }^{212}$ The above letter informed the Miller family that not only was their son in good company behind barbed wire, but that outside of the prison's walls, there existed support systems, be they family, friends or international institutions, that

allied soldiers captured by the Japanese army which was hampered by the Tokyo authorities' lack of cooperation. "1939 to 1945: Descent Into Hell," ICRC, accessed 4 June 2012, http://www.icrc.org/eng/who-weare/history/second-world-war/overview-2-world-war.htm.

${ }^{211}$ Erle Miller to Gladys Miller, 17 September 1941.

${ }^{212}$ Anthony Cohen, The Symbolic Construction of Community (London: Sage, 1985$), 17$. 
were in place to aid captured servicemen. In this second letter home, Miller appeared confident that with the support of these people, as well as a bit of 'luck', he would be able to endure his imprisonment, however long it might be. Having negotiated the demoralizing transition to prisoner, which had at its core the acceptance of an exceedingly less active presence in the war effort, Miller had begun his transformation into his new role as 'Kriegie'; a title that would see him through to the end of the war. ${ }^{213}$

Miller arrived at Stalag VIIIB at Lamsdorf, near the Lower Silesian city of Oppeln, Poland, at the end of September $1941 .{ }^{214}$ Given German military practice, prior to his entry into this permanent army run camp, Miller would have been deloused, photographed, fingerprinted, and basic information on his physical appearance, home address and next of kin would have been taken. As one of the largest prisoner of war camps from the Great War period, Stalag VIIIB became home to over 300,000 POWs over the course of the Second World War. ${ }^{215}$ These internees, living in close, poorly insulated quarters of about 180 men to one 80 by 30 -foot barrack block, suffered from limited fuel supplies and pest problems. ${ }^{216}$ For many of these inmates, Stalag VIIIB was known as the "Hell Camp."217

\footnotetext{
${ }^{213}$ Kriegsgefangene, the German word for 'prisoner', was quickly appropriate by Allied prisoners and shortened to 'Kriegie'.

${ }^{214}$ Miller, POW Journal, v.1, inside cover page. Lamsdorf served as a POW camp for three conflicts: the FrancoPrussian War of 1870-71, and the First and Second World Wars. At the outbreak of hostilities in 1939, the Germans designated Lamsdorf for Polish soldiers and then added British and Dominion POWs in 1940. It consisted of a vast array of grey, single-storey barracks blocks, many of which were dilapidated, plagued by serious overcrowding problems. This was also the location where the hands of 1000 airmen were bound for 18 -months in retaliation for the Dieppe raid. John Castle, The Password is Courage (London: Souvenir Press, 1985), 40.

215 "Report by American Inspector," 12 March 1941, Record Group 24, Library and Archives Canada, Ottawa, Ontario. These terrible conditions from previous wars repeated themselves in 1942 when overcrowding at Lamdsdorf began to cause serious problems and by 1943 it reached a crisis point. "Men were without blankets, with many forced to sleep on concrete floors; supplies of running water became increasingly irregular, and the camp's sanitation was so poor that medical officers feared an epidemic of dysentery." Gilbert, POW, 84 .

${ }^{216}$ Vance, Encyclopedia of Prisoners of War and Internment, 67.

217 "Report by American Inspector," 12 March 1941, Record Group 24, Library and Archives Canada, Ottawa, Ontario. The Germans failed miserably at controlling infestations, rats, and the overpowering stench. Straw-filled mattresses, or palliasses, hosted millions of sand fleas that attacked the men's skin. Jonathan Vance, "The Politics of Camp Life: The Bargaining Process in Two German Prison Camps," War \& Society, 10 (1992): 115.
} 
Life in a prisoner of war camp proved difficult to adjust to for Miller. Captured airmen went from a military environment, to an emasculated status wherein they offered no help to the war effort and maintained very few liberties. ${ }^{218}$ Miller's capture and the imposition of 'kriegie' status occurred swiftly and in understandably frightening circumstances; his adjustment to prisoner life, however, was a slow and uneasy process. This was a period of uncertainty for Miller as he transitioned into a new reality wherein the war, his role in it and the future were all unknowns. Throughout this transition, Miller relied very heavily on the support of others, both near and far, to help him come to terms with his new surroundings. This need for the companionship and support of others is quite apparent in the first letter Miller sent home from Stalag VIIIB on 12 October $1941 .^{219} \mathrm{~A}$ few lines into the letter, after asking that cigarettes, socks, and a toque be sent, Miller wrote:

Write lots of letters and if you can send them through the States. They arrive here very much faster also there is no restriction on number of parcels sent from there. I increased my allowance home to three quarters of my pay. Let me know if you are receiving it ok. Send me a pipe and tobacco also towels. Tell all my friends to send cigarettes. Don't worry about me. I hope you are all in good health. Write me all the news. You might also send me a deck of cards if its allowed. There is no news so will see you when the war is finished. ${ }^{220}$

\footnotetext{
${ }^{218}$ In accordance with the Geneva Convention of 1929, Chapter 4, Article 16, "Prisoners of war shall be permitted to complete freedom the performance of their religious duties, including attendance at the services of their faith, on the sole condition that they comply with the routine and police regulations prescribed by the military authorities. Ministers of religion, who are prisoners of war, whatever may be their denomination, shall be allowed freely to minister to their co-religionists." Article 17 stated, "belligerents shall encourage as much as possible the organization of intellectual and sporting pursuits by the prisoners of war"; so while freedom of religion was guaranteed, liberties of the mind and body were not explicit. "International Humanitarian Law - Treaties \& Documents," International Committee of the Red Cross, accessed 14 July 2012 , http://www.icrc.org/ihl.nsf/full/305?opendocument.

${ }_{219}$ Miller sent 23 letters from this camp and, in all but three of the letters, he requested something from the home front. While he did ask that food, clothing and hygienic accessories, such as handkerchiefs, towels, toothpowder and soap be sent across the Atlantic, his most common demand was for cigarettes.

${ }^{220}$ Erle Miller to Gladys Miller, 12 October 1941. In a later letter, Miller again suggested that his mother send parcels "through the American Red Cross [because] they will come must faster. Parcel which are sent through the States take a very short time compared to Canadian parcels." Erle Miller to Gladys Miller, 26 October 1941. While speed was a factor in Miller's letters, American Red Cross packages were especially welcome among POWs for their content which contained larger rations and elements that were excluded from Canadian packages such as peanut butter and cigarettes. "Eat, Drink, Smoke and be Creative," accessed 12 July 2012, http://phillipsamoore.com/edmoore/newmoorepage 13.html.
} 
This piece of correspondence, as demanding as it may outwardly appear, reflects Miller's intrinsic need for the companionship of others during this initial period of adjustment.

Despite Miller's requests and the efforts on his behalf made by those on the home front, the poor standard of care provided in Stalag VIIIB left Miller in a state of near starvation during the winter months of 1942 . In a small brown journal he received from his family in Castleford, he began to make note of his discomforts; this commentary does not appear in his correspondence home. The first entry he made about food came on 22 January 1942, when Miller wrote, "haven't eaten for two days."221 February did not see any improvement and these types of comments became more frequent as his nutritional health and mental well-being deteriorated in light of the camp's conditions. ${ }^{222}$ In these pages, Miller documented the limited quantity of food he was given, and the negative effect malnourishment was having on his body and state of mind. On a daily ration of " $1 / 4$ tin of milk, 1 tin of stew and 4 sugar cubes," Miller's attitude grew increasingly negative. In several entries made in February and March of 1942, he reported that he was "brassed off" or "brassed as hell."223 Miller wavered between irritation and lethargy, as he often remained in bed all day to conserve both heat and energy. ${ }^{224}$ This lack of nutrition, however, was most apparent in Miller's physique and he reflected in his journal that,

\footnotetext{
${ }^{221}$ Miller mentioned food or hunger 21 times in his journal between January and March 1942. Throughout these pages, he also offered commentary on the weather and his general state of mind.

${ }^{222}$ In these pages he wrote, "Very little to eat" and "Hungry as hell" and "Disgustingly hungry to-day with no news of parcels." While German food was typically poor in quality and insufficient in quantity, Miller's diet was supplemented, in a limited way, through Red Cross parcels and food packages from the home front. During his imprisonment at Stalag VIIIB, however, he received 6 parcels, none of which were dietary in nature. Miller, POW Journal, v.1, 61.

${ }^{223}$ Miller, POW Journal, v.1. 5 March 1941 \& 19 March 1942. In April, Miller noted in his journal that his rations had been cut. The bread ration dropped from 1/4 loaf per day to 1/6th. Miller, POW Journal, v.1, 7 April 1942.

${ }^{224}$ Miller, POW Journal, v.1.22 February 1942. Miller's entry from this day read, "Very little to eat and nothing to do. Sleep all day to keep warm and use as little energy as possible."
} 
after seven months in captivity, he was "loosing weight rapidly."225 By the very end of March, Miller wrote, “Nothing new. Life so hellish boring. Getting used to this half-starved state.”226

During his incarceration at Stalag VIIIB, Miller suffered from a general malaise known as barbed-wire disease, or "stalag syndrome." ${ }^{227}$ This condition was identifiable by its effect on the overall disposition of POWs and presented itself as an inability to concentrate, a sense of restlessness, memory failure and depression. For Miller, however, it was most apparent in his moodiness and general sluggishness. ${ }^{228}$ Yet ill-treatment had a minimal role in causing barbedwire disease; rather, it was the knowledge that one's captor, the enemy, was in control of so much of one's new life. One way that this top-down control was expressed in the camps was through the unpredictable command for an immediate parade, an event that Miller grew to despise. ${ }^{229}$ Prisoners could be forced to parade from "early morning till dark at night," as Miller was forced to do on 15 January 1942. ${ }^{230}$ During the parades, (Miller experienced one "before 6 a.m."), German officers would order parties to search the cramped huts for any sort of illegal or incriminating material. On 3 July 1942, after having his hut searched, Miller wrote in his journal: "Had search this morning and an unstamped tin of figs taken."231

While the guards irritated Miller, the monotonous cycle of camp life and its routine were worsened by the very fact that the duration of his captivity was seemingly indefinite. Miller's

\footnotetext{
${ }^{225}$ Miller, POW Journal, v.1.31 March 1942. He made mention of his weight loss again on 19 March 1942.

${ }^{226}$ Miller, POW Journal, v.1. 31 March 1942.

${ }^{227}$ Vance, Encyclopedia of Prisoners of War and Internment, 20.

${ }^{228}$ The POW journal entries reveal that Miller's disposition remained much the same until mid-May 1942. After his move to from Stalag VIIIB to Stalag Luft III, on 14 May 1942, Miller's journal entries contain more writing on his everyday life, indicating a more active lifestyle.

${ }^{229}$ German guards conducted roll calls once or twice a day on the Appelatz, German for parade square. Philip Lagrandeur, We Flew, We Fell, We Lived: The Remarkable Reminiscences of Second World War Evaders and Prisoners of War (London: Grub Street, 2007), 30. Searches could take up to six hours to complete. "They used to choose huts at random, doing two or three a week, so that we never knew which one would be next. However, sometimes we would get tipped off by one of the guards who was susceptible to our bribery." Fit.Lt. John Mahoney, "Stalag Luft III: Part 5," Roundel 2 (March 1950): 7.

${ }^{230}$ Miller, POW Journal, v.1,15 January 1942.

${ }^{231}$ Miller, POW Journal, v.1, 3 July 1942.
} 
journal indicates that war rumours circulated through the camp huts, as he noted of three specific tales of events beyond barbed wire, but his entries are more often filled with "no news today" or "nothing new." ${ }^{232}$ During this early stage of his captivity, however, Miller found comfort in these close quarters he inhabited with fellow inmates, and shared with his mother: "Everything is going fine here. I'm quite comfortable and in good health. I get enough to eat and our quarters are ok. I'm with my friends and we have a library and an opportunity to take course in electrical engineering etc..."233 Regardless of the comfort he took from fellow captives, Stalag VIIIB marked one of the darkest periods in his 4 years as a POW.

Miller endured seven and a half months at Stalag VIIIB before he was transferred to Stalag Luft III, located near the town of Sagan in the German province of Silesia. ${ }^{234}$ Miller would spend the longest phase of his captivity here and, fortunately, the camp was a significant improvement over Stalag VIIIB. ${ }^{235}$ As Miller heard word of his upcoming move, he noted in his journal on Sunday, 10 May 1942, that he was "on the list for de-lousin[sic] to-morrow morning. Should move Wed!"236 Miller may have been unsure about his imminent transfer and the state of

${ }^{232}$ On 23 March, Miller's entry read, “[...]Rumour Italy capitulated.” Miller, POW Journal, v.1, 23 March 1942. Eight days later, he wrote, "Rumour war is finishing." Miller, POW Journal, v.1, 31 March 1942. Months later, after the arrival of newly captured airmen, Miller relayed their words in his journal entry, writing, "According to the new blokes should be over this year." Miller, POW Journal, v.1, 6 July 1942. While these rumours provided hope for the inmates of Stalag Luft III, or any inmate who participated in such war gossip, their claim to a prompt cessation of hostilities was, of course, far from accurate.

${ }^{233}$ Erle Miller to Gladys Miller, 21 November 1941. The following quote from a letter Miller sent home in November 1941, highlights the centrality that his friendships played in his new world. While Miller's tone towards his surroundings varied throughout his correspondence home, the importance of his friendships, and the role that they played in informing his acceptance of his surroundings, is an element that does not change in the 117 letters that he sent as POW.

${ }^{234}$ Miller, POW Journal, v.1, 1 January 1942

${ }^{235}$ When Miller arrived at Stalag Luft III, it would have consisted of two compounds: East, which held roughly 500 officers, and Center, which was home to some 1,000 noncommissioned officers. Due to the increasing numbers of captives, Stalag Luft III expanded in April 1943 to include North compound, for officers, and again in September 1943, with the construction of South compound, for American officers. At its height the camp held well over 10,000 POWs. Vance, Encyclopedia of Prisoners of War and Internment, 283.

${ }^{236}$ Miller, POW Journal, v.1, 10 May 1942. 
the next camp, but the excitement expressed in this last entry perhaps indicates that he was hopeful that its conditions would be better than those of Stalag VIIIB.

After a night of travel, Miller arrived at the newly opened Stalag Luft III camp, on 14 May $1942 .{ }^{237}$ This camp was created as a result of the Luftwaffe's decision to confine all airmen to one camp and, as a result of the prestige associated with Allied airmen, this camp provided a wealth of amenities intended to ease the restlessness of its captives. ${ }^{238}$ The letters Erle sent home during the spring and summer of 1942 confirm that the conditions at Stalag Luft III were an immeasurable improvement:

As you can see by the new address on this card I've moved to another camp. It is much better than the last. This camp is run by the German Air Force and the last camp was run by the army. They are far more agreeable and easier to get along with. We have a lovely library here and plenty of space for sports. We have two hot showers per week and double tier beds. There is absolutely no comparison with this and the last camp. [...] I'm in good health and pretty comfortable now. ${ }^{239}$

The first 10 months of his captivity had been exhausting, as Miller endured the draining adjustment to captivity at one of the worst camps of his internment. While Stalag VIIIB had been wanting in all respects, this new camp marked the beginning of a significant improvement in his prisoner of war experience. As indicated in these letters, Stalag Luft III provided its captives with more than the basic essentials guaranteed to them by the Geneva Convention of 1929 and, as a result, Miller enjoyed a period of relative contentment. It was also during this time that Miller's correspondence with the home front regained some semblance of regularity and reliability. ${ }^{240}$

\footnotetext{
${ }^{237}$ Stalag Luft III opened on 21 March 1942.

${ }^{238}$ Mackenzie, The Colditz Myth, 166.

${ }^{239}$ Erle Miller to Gladys Miller, 18 May 1942.

${ }^{240} \mathrm{He}$ wrote home in June and informed his family that he had received parcels from them, as well as letters from friends in the Ottawa Valley community: "Thats the first tobacco I've received from you but got my book parcel and first clothing from home." Erle Miller to Gladys Miller, 6 June 1942. The acknowledgement of goods received was
} 
Miller divided the back pages of his journal into different sections for letters and parcels and took note of every piece of correspondence and every item he received during his captivity. ${ }^{241}$ He would indicate the date on which he received the item, the sender and, in the case of parcels, their contents. While these lists served as tangible reminders of the support networks he had beyond the wire, they also indicate that the Miller family was at this core of this community of care. From them Miller received 308 letters and 34 parcels between January 1942 and the end of the war. Outside of family, Miller received 218 pieces of correspondence from his friends in Castleford and local organizations in the surrounding Ottawa Valley. While these letters are not contained in the Miller Collection, the contents of the 164 parcels he received from this large group were recorded by him in his journal and reveal the wide variety of goods he received during his four years as a prisoner of war. ${ }^{242}$

In addition to the routine parcels sent from the Red Cross, resources were traditionally sent to POWs by their local neighbourhood communities. ${ }^{243}$ Miller's journal indicates that he

not present in the letters Erle sent home while at Dulag Luft and Stalag VIIIB, but remained a constant feature of his correspondence from Stalag Luft III.

${ }^{241}$ As is reflected in Miller's journal, he received 477 letters, broken down into the following senders: 308 letters from his family; 72 letters from Marg K; 14 letters from Mrs. Smith; 12 letters from Bud Smith, and Norma; 7 letters from the Canadian Legion; 5 letters from Stanley Smith; 3 letters from Iris Shaw, Mrs. King, and Villy; 2 letters from Glen, Mrs. Greenfield, Ireton, Mrs. Jamison, the Red Cross, Mrs. Reid, and the Service Bureau;1 letter from the Air Ministry, Aunt Lizzie, Aunt Mabel, Mrs. Asselin, Mrs. Brown, Mr. Burnwell, Mr. Campbell, Mrs. Eld, Grandma, Mrs. Graykowski, Mrs. Hanna, Howard Clereoux, Mrs. Hunt, Jim McGavey, J. Pashey, Mrs. John Rose, J. Wallace, Mrs. Matheson, Mr. Moreland, Mr. Simpson, Tom Letsing, Tom Plant, the YMCA, and Mrs. Vincent Massey (the wife of the Governor General of Canada). The names and tabulations reflect how Miller entered the correspondence into his journals. While he, for the most part, entered either a Mr. or Mrs., on several occasions he only provided a first or last name. Such references could indicate that these senders were his friends or extended family members.

${ }^{242}$ These letters were sent to Miller during his incarceration, and as they are not part of the Miller Collection, it can be assumed that he parted with these letters during his forced march in April and May 1945. Miller received 213 parcels during his four year as a prisoner of war. The receipt of these packages can be broken down into the following categories: 132 cigarette parcels; 25 parcels of fiction 1 books; 12 personal parcels; 11 tobacco parcels; 7 course material parcels (drawing, geology, mathematics, trigonometry, and aviation); 7 food parcels; 6 clothing parcels; 6 sport parcels (football, skates, glove); 5 game parcels; 1 sleeping bag parcel; and 1 toilet articles parcel from the Red Cross.

${ }^{243}$ Canadian parcels traditionally contained the following items: whole milk powder; butter; cheese; corned beef; pork luncheon meat; salmon; sardines; dried apples; dried prunes; sugar; jam; pilot biscuits; eating chocolate; salt 
also received cigarette parcels from the larger Ottawa Valley community starting in August, $1942 .^{244}$ This was likely in direct response to a front page article printed in the 16 July copy of the Renfrew Mercury, which featured Miller's picture, and a title that announced, "Canadian Prisoners of War in Germany Like to Get Cigarets and Chocolates."245 The article read:

Mr. and Mrs. Donald Miller, of Castleford, have been receiving lately a nice lot of mail from their son Erle. His correct address is: Prisoner of war post -

Kriegsgefangenenpost, Sgt. Erle S. Miller, Canadian Prisoner of War no. 9591, Staglag[sic] Luft 3, Germany. ${ }^{246}$

During his imprisonment, Miller received a total of 58,900 cigarettes. ${ }^{247}$ A startlingly large figure, it is highly unlikely, however, that Miller smoked all of what he received as a prisoner of war. Cigarettes were used by the POWs as 'currency' to bribe guards to overlook minor infractions in camp discipline or trade for contraband articles. ${ }^{248}$ 'Foodacco', referring to the exchange of food and tobacco which developed within camps, occurred mainly as a result of

and pepper; tea; and soap. As cigarettes were not included in Canadian Red Cross parcels, these home front communities were instrumental in providing tobacco to Canadian POWs. Tisdall, "Final Report," 283.

${ }^{244}$ Miller received a total of 5 packages in July, which were all cigarette parcels and amounted to 1500 smokes. In August, again he received 5 parcels, however only 2 were cigarette packages totally 1200 . The fall of 1942 saw an increase in the amount of cigarettes he acquired: September, 1600, October a low of 500; November high of 2700 cigarettes.

${ }^{245}$ Renfrew Mercury, 16 July 1942.

${ }^{246}$ Renfrew Mercury, 16 July 1942.

${ }^{247}$ Calculated from Miller, POW Journal, v.1. Cigarettes sent through Prisoner of War Organizations were ordered and paid for by a relative or friend, and then sent directly from the manufacturer. While the Canadian government did not send cigarettes to its captives overseas, fortunately for POW smokers, the British and American governments sent vast quantities of tobacco and cigarettes to Germany and Italy. From the beginning of 1941 to March 1945, the Prisoner of War Organization sent over 6 million ounces of tobacco and nearly 1.5 billion cigarettes to camps in the above mentioned countries. R.A. Radford, "The Economic Organization of a P.O.W. Camp" Economica (November 1945), 6.

${ }^{248}$ Some prisoners were able to turn a profit off the 'foodacco' system by becoming 'traders' and, as the title suggests, would buy and sell goods to fellow captives with the camp. At Stalag Luft III the actions of one trader named Mac have been noted in The Roundel and read: "Suppose I told him I wanted a pair of swimming trunks, and was prepared to offer ten chocolate bars, Mac would hunt all over the camp till he found someone who had a pair of trunk and was willing to sell them for eight or nine bars. He would pocket the difference, and everyone would be happy. In all our dealings with Mac, I never head of a dissatisfied customer. [...] It took all kinds to make our world." Flt.Lt. John Mahoney, "Stalag Luft III: Part 5," The Roundel 2 (March 1950): 6. For more on this in-house practice, see Kinsley Brown, Bonds of Wire: A Memoir (Toronto: Harper Collins Publishers, 1989),142-3; Robert Garioch, Two Men and a Blanket: Memoirs of Captivity (Edinburgh: Southside, 1975) 118-9, M.N McKibbin, Barbed Wire: Memoirs of Stalag 838 (London: Staples Press 1947), 43-4. 
the uneven, or unequal, receipt of parcels by camp inmates. Contents of parcels were effectively redistributed through a points based 'currency' which depended upon the popularity of various parcel items at given times. ${ }^{249}$ While the Red Cross issued rations of 25 and 50 cigarettes per man per week, which came in relatively regularly, there were periods where this 'camp money' would either be in abundance or in severe shortages. ${ }^{250}$ As a result of this fluctuation, the quantity of cigarettes in the camp could either increase the price of goods when smokes were abundant, or force prices to drop when cigarettes were scarce. ${ }^{251}$ When prisoners were well supplied with these scarce luxury items, however, they were less reliant on the formal prison system, and life behind barbed wire was slightly easier.

In Stalag Luft III, Miller began to spend large amounts of his leisure time in the camp's library. ${ }^{252} \mathrm{He}$ wrote home about this facility in 5 out of the first 13 letters he sent from Stalag Luft III, which indicate the significance and importance that this space had in his daily routine. ${ }^{253}$ It was a site that demanded little physical exertion on behalf of its patrons, and,

${ }^{249}$ Royal Canadian Air Force. The Roundel 2 (January 1950), 24.

${ }^{250}$ The delivery of cigarettes to prisoners of war remained relatively constant until the summer of 1944, at which point an increasingly limited supply made the continual delivery of this item to its intended recipients unfeasible. By January 1945, the Red Cross ran out of cigarettes. Radford, "The Economic Organization," 6.

${ }^{251}$ While captors could provide the odd cigarette during nicotine droughts, more often than not, men did without or smoked ersatz cigarettes. The demand for something to smoke was so great that almost anything combustible would do. Held in the transit camp at Salonica, Joseph Pryce observed that "dried mint leaves, shredded and wrapped in strips of newspaper, was an innovation from which a great number of men derived a certain amount of enjoyment." Other substitutes included grass, leaves of all kinds, coffee grounds and even manure. J.E.Pryce, Heels in Hell (London: Minerva, 1998), 60.

${ }^{252}$ The libraries of the German POW camps in the Second World War were an expanded effort on the patchwork system that had been in place throughout the Great War. In Britain, the Red Cross, with the assistance of the Order of St. John of Jerusalem, established The Indoor Recreations Section of its Prisoner of War Department in the late autumn of 1940. This section was initially named the Fiction and Games Section, but was later renamed the Indoor Recreations, Books, Games and Music Section. The Fiction and Games section provided light reading along with games, such as Monopoly, chess, draughts, dominoes and packs of cards. For more on this programming, see Robert W. Holland, ed, Adversis Major: A Short History of the Educational Books Scheme (London: Staples Press/British Red Cross, 1949).

${ }^{253}$ In his memoirs, RAF officer Robert Kee notes, "We could not have lived without books. They were the only sure support, the one true comfort. When food was short, clothing scarce, blocks overcrowded and underheated[sic], and war news bad, there were always books. In reading one had a pleasure of which, like sleep, one could never be deprived. I remember the books which I read in that time with a great love." Robert Kee, A Crowd is not Company (London: Sphere, 1989), 115. 
through its books, was able to encourage prisoners' imagination and stimulate their thoughts. ${ }^{254}$ Libraries provided what POWs tried so hard to achieve through their escape tunnels; they offered access to the world beyond the confines of the prisoner of war camp. Even though most could not find physical escape from the camp's confines, any POW who could read could find it in the library. ${ }^{255}$

In the Stalags, the provision of books varied widely but a typical library of 1,050 volumes, would contain roughly 600 fiction and general reading books; 150 textbooks, 100 on vocations, professions and trades; 50 books on history and travel; 50 on science and medicine; 50 on religion; 25 biographies; and 25 on poetry and art. ${ }^{256}$ Miller was fortunate to be imprisoned in two Luftwaffe run camps that operated substantive libraries - Stalag Luft III and Stalag Luft VI. ${ }^{257}$ Regardless of his good fortune, Miller continued to send home requests for

254 "Request" forms were sent to camps, and asked prisoners to indicate their previous academic experience, subjects they wished to study, and books they required in order to do so. When book orders were received, texts were ordered, packed and shipped to the POWs, who were required to return an acknowledgment card. When prisoners were finished reading their new books, they were placed in that internee's central camp library. David Rolf, "The Education of British Prisoners of War in German Captivity, 1939-1945," History of Education 18 (1989): 257.

${ }^{255}$ In addition to fictional works, the Indoor Recreation Section formed the Educational Book Section in February 1940, which supplied books to assist in the educations of POWs; by the end of May 1942, 69,400 educational books had been sent to POW camps. P. Crambay and G Briggs (compiled), Red Cross and St. John: The Official Record of the Humanitarian Services of the War Organization of the British Red Cross Society and Order of St. John of Jerusalem 1939-1947, (London: Sunfield and Day, 1949), 212. Miller studied German, Math, Navigation, Trigonometry, Aviation and was most diligent in the pursuit of French grammar courses. For Miller, educational courses remained relatively informal, as none of his correspondence or personal writing has any mention of quizzes, tests or examination. Such regimented learning was propelled through the increase in available course material through the above mentioned organization. For more information on education within German POW camps, see Roger Shinn, War and Rumors of Wars (Nashville, Tenn: Abingdon Press, 1974), 4-24.

${ }^{256}$ Andre Vulliet, Preliminary Report of the War Prisoners Aid, Young Men's Christian Associations during World War II. (Geneva, Switzerland: International Committee of the Young Men's Christian Associations, 1946), 52. The International Committee of the Red Cross created an Advisory Committee on Reading Matter for Prisoners to coordinate the educational program and to act as a controlling committee for a number of bodies, including the Young Men's Christian Association (YMCA), the International Bureau of Education, and the International Federation of Library Associations.

${ }^{257}$ While Stalag Luft VI's library boasted over 6,000 titles, other camps were poorly provided for, such as Stalag XIIA at Limburg which had acquired just fifteen books by 1944 . Such differentiation was a result of the status of the Luft camp vs. the army camp at Stalag XIIA. Just as generally conditions were markedly in airman camps, so too were their library facilities. The difference in book quantity was also due to the fact that this camp was meant to serve as a transition camp. David Shavit, "The Greatest Morale Factor next to the Red Army": Books and Libraries in American and British Prisoner of War Camps in Germany During World War II," Libraries and Culture 34 (Spring 1999), 120-1. 
educational material: "There are plenty of fiction books in library here so any books you send make them language, mechanics and mathematics. French \& Spanish grammar, algebra \& diesel course \& anything interesting."258

Outside of the charitable and humanitarian organizations, which were the main pillars in this provisional supply chain, Miller's family was also actively involved in sending reading material overseas. ${ }^{259}$ The works they chose to send, however, had to adhere to the guidelines set forth by the Canadian Red Cross Society which stated that, "books of selected authors and subjects may be sent, but any by Jewish authors are not allowed, nor any dealing with subjugated countries."260 Content with the library's fiction offerings, Miller requested that only educational material be sent from Castleford. His requests typically echoed the postcard he sent home on 9 August 1942, which read, "Say Mom if you could send me a French and Spanish grammar they would come in quite useful also any mathematical or mechanical educational books you think I'd be interested in."261 Miller's family had been informed by the government of a firm through which they could order books. Private book-buyers also played a significant role in the delivery of materials to incarcerated servicemen overseas, as families of POWs would send in their order,

\footnotetext{
${ }^{258}$ Erle Miller to Gladys Miller, 4 August 1942.

${ }^{259}$ There were strict regulation that nothing was to be sent abroad that might aid the Axis, which meant books containing detailed maps, charts and tide tables of the home country were banned, or the offending articles were removed, as were works on weapons and the military as well as the latest scientific and technical books. All books were double-censored, first in the Allied country, from which it was sent, and then again in Germany. In Germany, the situation was more complex. Holland, Adversis Major, 47. In addition to a standard prohibition on books that might help any potential escaper or saboteur, the sender also had to be careful not to offend the delicate sensibilities of the totalitarian state by sending unacceptable material; the latter was clearly on a more case-to-case base. While the banned list was extraordinarily thorough, it did have some omissions: John Buchan's war novels Greenmantle and Mr Standfast; the American novelist Winston Churchill was banned, but My Early Years by Winston Spencer Churchill was not attributed to the Prime Minister and was, therefore, let in; Scouting for Boys as the Boy Scouts were a vital part of the British Secret Service, among others.

${ }^{260}$ For an understanding of book preservation and destruction under the Nazi regime, see Leonidas Hill, "The Nazi Attack on "Un-German" Literature, 1939-1945" in The Holocaust and the Book: Destruction and Preservation, ed. Jonathan Rose (Boston: University of Massachusetts Press, 2001), 9-46.

${ }^{261}$ Erle Miller to Gladys Miller, 26 April 1942. In another note, he wrote, "In next book parcel could you send French \& Spanish \& exercise books. Gone thru two French grammars \& read several hundred books. Nice library here." Erle Miller to Gladys Miller, 9 August 1942.
} 
and the books would be sent by these firms directly to the POWs. In 1942, for example, Miller received 6 book parcels from the Castleford community. ${ }^{262}$

The library and reading became compulsions for Miller and he wrote home on 7 May 1943, almost a year to the day after his transfer to Stalag Luft III, that he had "read well over 200 books" at this camp's library, which was a clean place, capable of seating about 80 men. $^{263}$ While his letters home contained references to several works of fiction he enjoyed, Miller was tireless in his efforts to document all the texts he had read in the first of his two POW journals. ${ }^{264}$ As a form classification, Miller wrote down the name of the text he had read, its author and a chosen descriptor which indicated his ranking of the text in three divided columns on the back side of the first 10 pages of his journal. ${ }^{265}$ In this latter column, Miller listed 7 books as 'Excellent'; 35 as 'Very Good'; 3 as 'Quite Good'; 64 as 'Good'; 134 as 'Fair'; and 21 as 'Poor' while at Stalag Luft III. ${ }^{266}$

\footnotetext{
${ }^{262}$ Erle Miller to Gladys Miller, January to December 1942. Miller received 4 parcels from his parents, 1 from his sister Margaret and 1 from Reverend Wright. While he indicated in his journal the date and sender of these book parcels, he did not make note of their titles. Throughout his incarceration, Miller would simply write 'book' when he had received reading material, and therefore it is not possible to note what type of literature he was receiving.

${ }^{263}$ Erle Miller to Gladys Miller, 7 May 1943. The World's Alliance of Young Men's Christian Association reported that the demands for books was insatiable and was never fully met. Stalag Luft III had two libraries per compound: one for reference material and one that served as a general lending library for works of fiction and nonfiction. The fiction library was especially important to prisoners, and, according to one prisoner of this airman camp, was "probably the greatest morale factor in the camp next to the Red Army." Shavit, "The Greatest Morale Factor Next to the Red Army," 5.

${ }^{264}$ His letters home contained the following recommendation on the works he was reading: "Favourite authors are A.J.Cronin, Steinbech, T.Smith, Nordhoff \& Hall. If you get a chance read The Stars Look Down by Cronin also The Cidadel." Erle Miller to Gladys Miller, 7 May 1943. "Can recommend Stars Look Down By A.J.Cronin also Citadel by same author. Rains Came by Louis Bromfield, My Son My Son - Howard Spring. How Green was my Valley by Richard Llewelyn.” Erle Miller to Gladys Miller, 24 February 1944.

${ }^{265}$ Miller, POW Journal, v.1, 1-10.

${ }^{266}$ Miller, POW Journal, v.1, 1-10 Nowhere in his journal does Miller indicate what differentiated a book from being 'excellent' or 'poor' or the subtle nuance between a book that was 'very good' in comparison to one that was 'quite good'. This classification, however, can be interpreted as a form of control that Miller expressed over his immediate environment, in order to garner a sense of control over his general surroundings.
} 
The novels that picqued Miller's interest were in some way connected to his life before his incarceration. ${ }^{267}$ While Miller read several novels that were based on the lives of female protagonists or which were situated outside of his own geographic and temporal knowledge, he craved well known, popular novels detective fiction, westerns, travel and biography. ${ }^{268}$ This interest is reflected in his ranking of the following books as 'Excellent': "Thomas A. Edison by William A. Simonds, Gold Nugget Charlie by Frances Loyd-Owen, School of Eternity by Harry Hervey, Random Harvest by James Hilton, Gone with the Wind by Margaret Mitchell, The Stars Look Down by A.J.Cronin, Way of a Transgressor by Negley Farson and Thunder in the Earth by Edwin Lanham." 269 The 'Excellent' works identified in Miller's journal are principally adventure stories but as Miller's time inside the camp continued, his reading interests embraced English classics, biographies, military, travel and history. ${ }^{270}$ Miller was adamant that his family not "send me any fiction books," which possibly reflects his general satisfaction with the state of Stalag Luft III's library. ${ }^{271}$ As he read his way through his year of imprisonment at Stalag Luft III, Miller's appreciation for Cronin's works continued, and he wrote home in May of 1943 that, "Have read well over 200 books at this camp. Favourite authors are A.J.Cronin, Steinbech,

${ }^{267}$ Of these works identified as "Poor", 16 were read and ranked within the first 5 pages of Miller's journal which suggests that he developed the ability to actively critique a book based on previous preferences. In the following 5 pages, there are only 5 books that are ranked as "Poor" with the majority of works read receiving either a "Good" or "Very Good." Miller, POW Journal, v.1, 1-10.

${ }^{268}$ Shavit, "The Greatest Morale Factor Next to the Red Army," 114. "The most highly demanded books by order of importance were: (1), well-worn popular novels; (2), detective fiction; (3), western fiction; (4), travel; and (5) biography." Ibid., 123. Several examples of books Miller thought were 'Poor' are, Millionaire Widow by Nina Bradshaw, Dragon Tail by Cecil Adiar, and She was Sheriff by Charles Snow. Miller, POW Journal, v.1, 1-10. ${ }^{269}$ Miller, POW Journal, v.1, 1-10.

${ }^{270}$ He was, however, particularly taken by the writings of Scottish physician and novelist, A.J. Cronin, and wrote home on several occasions suggesting his works' to family in Castleford. After reading The Citadel, which he deemed 'Good', Miller remarked in a letter home that, "I read a good many books. Some weeks read nine \& ten books. One of my favourite authors is A.J. Cronin." Erle Miller to Gladys Miller, 18 October 1942. Miller ranking of this text may have been slightly critical as The Citadel had a far reaching influence within the literary field, as well as the social landscape. While it won the "National Book Award, Favorite Fiction of 1937" in the United States, the work's criticism of the medical practices of the time allegedly incited the establishment of the National Health Service in the United Kingdom. R. Samuel, "North and South: a Year in a Mining Village", London Review of Books 17 (1995): 4.

${ }^{271}$ Erle Miller to Gladys Miller, 6 February 1943. This comment appeared in two of the letters Miller sent in 1942 and six of the letters he sent in 1943. 
T.Smith, Nordhoff \& Hall. If you get a chance read The Stars Look Down by Cronin.,272 Cronin's name, however, appeared 4 times in the letters Miller sent home from behind barbed wire, and 2 of these mentions included recommendations to several of the works Cronin wrote; of these recommendations, The Stars Look Down received Miller's highest praises. ${ }^{273}$

Cronin's The Stars Look Down chronicles the various injustices in an English coal mining community beginning in the pre-World War One period and spanning into the late 1930s. ${ }^{274}$ The protagonists of this piece of literature, alongside the leads in the other novels identified as 'Excellent', were not simply characters in works of fiction, but in light of their adventures, misfortunes and determination were perhaps sources of inspiration and enjoyment for Miller. These works of fiction and other books were understood by many internees as the "best escape."275 Through his readings, Miller would vanish into whatever world was created by the authors of the 347 books he read during his imprisonment. ${ }^{276}$ While Miller read in order to distract himself from his surroundings, he also engaged in reading for personal improvement, as can be inferred through the course work while a POW. This may have not only helped him cope with his incarceration, but also enabled him to look forward to his future when he was freed from his barbed wire prison.

Miller's personal reflection on what would come after the war ended, however, pre-dates his escape into Stalag Luft III's library and is present in both his correspondence with his mother

\footnotetext{
${ }^{272}$ Erle Miller to Gladys Miller, 7 May 1943. While he did mention 4 other authors (Steinbeck, T.Smith, Nordhoff \& Hall) in this last excerpt, this was the only time they were noted in his correspondence home.

${ }^{273}$ Erle Miller to Gladys Miller, 7 May 1943. "If you get a chance read The Stars Look Down by Cronin also The Cidadel. Loads love Erle." From Stalag Luft VI, Miller wrote, "Three books I can recommend as any good are The Stars Look Down, Halter's Castle \& The Citadel by A.J.Cronin. You can probably get those in the library at home." Erle Miller to Gladys Miller, 23 October 1943

${ }^{274}$ Cronin crafted this work to represent the struggles of escaping from the confines of the working class, which Miller might perhaps have connected to his life behind barbed wire.

${ }^{275}$ Shavit, "The Greatest Morale Factor next to the Red Army," 21.

${ }^{276}$ This statistic is reflective of the number of book titles and rankings Miller noted in his POW journal. Miller did not include the course material he read in these lists and, in addition to these works, it is possible that he read more texts, but did not make mention of them in this table. Miller, POW Journal, v.1, 1-10.
} 
and his private war journals. Miller sent home a postcard on 19 October 1941 of only a few lines consisting primarily of requests for cigarettes, news and correspondence. On the card's third line, Miller also asked that his mum, "Keep a lookout for a good job that might suit me."277 These requests appeared in three other letters sent from behind barbed wire in 1941 and reflect Miller's focus on returning home after the war. ${ }^{278}$

After Miller's transfer to Stalag Luft III, however, such requests were no longer part of the letters he sent home. Instead, Miller's focus on the future continued in his private journal. As Miller's camp surroundings improved, and as he adjusted to his captivity, he took it upon himself to plan for the possibilities of his future. On the back of the 25th page of his journal, Miller itemized 27 "PROBABILITIES" of what his life could be after the war. ${ }^{279}$ They were:

1. Start up restaurant and taxis and dance

2. Start up some kind business

3. Remain in R.C.A.F

4. Work Home for awhile

5. Travel

6. Steel factory

7. Mine up North

8. Any Available job

9. Take some course [government props]

10. Take pilots course R.C.A.F or U.S.A

11. Take pilots course go up North

12. Get job in States

13. Travel to South Seas

14. Travel to South America

15. Start up a ski tow and hotel at Banff

16. Invest money in mine

17. Plantation South Seas

18. Buy and sell trade

19. Buy boat and go into fishing business

\footnotetext{
${ }^{277}$ Erle Miller to Gladys Miller, 19 October 1941. This was the first letter that contained this request.

278 "Keep a look-out for a good job for me." Erle Miller to Gladys Miller, 2 November 1941. "Don't worry about me. Keep a look-out for a good job for my return." Erle Miller to Gladys Miller, 9 November 1941. "Keep your eyes open for any good job that might be open for me when I return." Erle Miller to Gladys Miller, 21 December 1941. ${ }^{279}$ Miller, POW Journal, v.1, 74. The use of the root word 'probable' here indicates great confidence and optimism on Miller's behalf. While 'possibilities' as a title would have presented endless, and even unrealistic, opportunities, the use of 'probabilities' as the title for this page suggests that any one of the jobs or goals suggested on this page had the very real chance of happening.
} 
20. Get job driving brewery trucks

21. Start up a beer parlour

22. Buy couple of trucks and go into trucking business

23. (Recreation) Trip to South America by motor-car via States up one coast and down the other

24. Mixed farming project

25. Take Diesel Course

26. Club on border

27. Bahamas - tomatoes, etc... ${ }^{280}$

These 27 options differ greatly but, at the same time, somewhat overlap. While this list suggests that Miller believed he could travel the world after the war, he was somewhat undecided as to what his career would be. Apart from some vague job descriptions, he seemed to limit his chosen fields of employment either to areas already familiar to him, or at least those somewhat similar to each other in scope. ${ }^{281}$ Six of the chosen job 'probabilities' were start up ventures, which denotes a measure of ambition in the 21-year-old captive and a desire to be his own boss. Whilst in captivity, he mused over the ways in which his independence and resolve would translate into a form of paid income. Conversely, Miller's options 3,10, and 11, were linked to his longstanding eagerness to become a pilot. ${ }^{282}$ Unlike his planned business initiatives these air-minded 'probabilities' were familiar territory to Miller and present a more conservative post-war plan.

Having chosen so many 'Probabilities' for his future, however, Miller deliberated further over one option. On the reverse side of the 40th page of his POW journal, Miller extrapolated on option " 21 . Start up a beer parlour." 283 This page is broken down into two columns, and reads: $\underline{\text { Start Beer Business }}^{284}$

\footnotetext{
${ }^{280}$ Miller, POW Journal, v.1, 74.

${ }^{281}$ Miller, POW Journal, v.1, 74.

${ }^{282}$ Miller, POW Journal, v.1, 76.

${ }^{283}$ Miller, POW Journal, v.1, 76.

${ }^{284}$ Miller, POW Journal, v.1, 76
} 


\begin{tabular}{|c|c|}
\hline $\begin{array}{l}\text { 1. Big Profit } \\
\text { 2. Doesn't require large capital } \\
\text { to start } \\
\text { 3. Easy to handle } \\
\text { 4. Doesn't require large } \\
\text { amount experience } \\
\text { 5. No large overhead } \\
\text { 6. Generally a demand } \\
\text { 7. Easy work } \\
\text { 8. Hours O.K. } \\
\text { 9. Sidelines } \\
\text { 10. Easy to keep account } \\
\text { of } \\
\text { 11. If hotel - extra rent. }\end{array}$ & $\begin{array}{l}\text { 1. License required } \\
\text { 2. Transport cost if in mining } \\
\text { town } \\
\text { 3. Breakage } \\
\text { 4. Refrigeration \& upkeep } \\
\text { building. }\end{array}$ \\
\hline
\end{tabular}

For Miller, the advantages, although not completely realistic or entirely accurate, far outweighed the disadvantages of starting up a beer business. It was, most importantly, a job that he believed he could succeed at and that he looked forward to beginning after the war was over. These options convey Miller's personal understanding of what opportunities lay at the other side of his internment. While they may appear slightly haphazard, the list serves as a written representation and insight into Miller's conception of his potential place in the post-war world. Such a list also identifies the strength of Miller's imagination, which was one of his main coping mechanisms during his incarceration. Finally, Miller's chosen "Probabilities" also speak to his growing confidence in himself, his abilities, and, most poignantly, his assertion that this war would end and that when it did, he would, again, be in control of his life. ${ }^{285}$

${ }^{285}$ Ibid. 
Miller was transferred again on 16 June 1943, to the newly opened facilities for NCOs at Stalag Luft VI at Heydekrug, located on the border of East Prussia and Lithuania. ${ }^{286}$ This camp offered amenities on par with those of Stalag Luft III, and while Miller continued to read voraciously, he also began to participate in sports with fellow internees. ${ }^{287}$ Recreation was an element that this camp was known for, as it was well supplied with games and sports equipment from the YMCA and other organizations provided through the Red Cross. ${ }^{288}$ These parcels allowed for a variety of sports to be played, such as cricket, rugby, field hockey, and baseball. In 1943 alone, the YMCA shipped over 10,000 soccer balls, 6,900 pairs of boxing gloves, 8,000 soft balls, 400 baseballs, 650 American footballs and 25,000 table-tennis balls to German camps. $^{289}$

Miller's first postcard from the camp highlights his new engagement with sporting activities: "I'm in pretty good health \& playing quite a bit of basketball, etc..." ${ }^{290}$ This note also draws attention to one of the key functions of sports for POWs: when prisoners had enough food,

${ }^{286}$ Gilbert, POW, 76. This camp was opened in early June of 1943. It had been a former military barracks, which meant that upon his arrival, Miller would have found well-constructed brick-built accommodation blocks that were well heated. The camp was divided into three compounds: one for Americans, one for the British, and the third for both nationalities. These brick buildings were supplemented by wooden huts, which provided a maximum capacity at just over 6,000 men. The Nazis constructed camps as Far East as they could in order to minimize the chances of escapees reaching freedom.

${ }^{287}$ Miller had mentioned the sports facilities at Stalag Luft III, but never his participation in these activities. For example, on 23 May, Miller sent a letter home to his mother, informing her that his present camp (Stalag Luft III) had a "lovely library and sports." Physical activities were not mentioned again in the note, but Miller added, "I do a lot of reading \& a bit of studying. [...] Any educational books are appreciated." In doing so, Miller presents reading and studying as a priority over sports, and while the camp had these facilities, his correspondence home and personal journal do not indicate that he engaged in sport at Stalag Luft III. Erle Miller to Gladys Miller, 23 May 1942.

${ }^{288}$ In facilities, such as Stalag Luft VI, where the commandant and other conditions, such as space and provisions, allowed for it, sports grounds "were in constant use from dawn until dusk except during role calls and meal times." John Dreiford, "Anything but Ordinary: POW Sports in a Barbed Wire World," Journal of Sports History (Fall 2007), 419.

${ }^{289}$ Prisoners of War Bulletin, 1, no. 5 (October 1943): 2.

${ }^{290}$ Erle Miller to Gladys Miller, 28 July 1943. Miller's note to his family on 13 August clearly focuses on this physical health element, as he wrote, "Am playing football, softball, rugby $\&$ basketball this year. Am in pretty good shape." Erle Miller to Gladys Miller, 13 August 1943. While Miller's references to sports and leagues indicates that he was engaging in recreational activities with other prisoners, he does not mention any of them by name, as he did in his letters during active service. Given the limited amount of space he had for his weekly correspondence, one can assume that Miller chose to use these lines to make requests of the home front, rather than spend time describing, in too great a detail, his barbed wire environment. 
these activities helped keep their bodies relatively fit. The German camp authorities allowed prisoners to take up 'wholesome' pursuits, as it was believed that if prisoners' leisure time was occupied, they would not attempt to escape or cause mischief. In light of all the hardships that prisoners of German POW camps encountered, athletics played an important role in maintaining the mental and physical well-being of inmates.

As well as making for a generally healthier and happier body of prisoners, sports were a way for captives to reassert pride in themselves and in their home countries. This patriotism was achieved through intramural sports teams and competitions which, as Miller experienced, were often run along national lines. While football was played primarily by British players all year long, Commonwealth POWs also actively engaged in cricket and rugby. ${ }^{291}$ While American POWs were recognized for their love of baseball, softball and basketball, Miller wrote home 15 times about his enjoyment and involvement in basketball. This activity appeared for the first time in July of 1943, when Miller wrote home that, "I'm now playing soft ball for our team, also football \& basketball." ${ }^{292}$ Over the course of a year, Miller was able to go from team player to team captain and wrote home on 5 July 1944 that, "I'm captain of a pretty good basketball team this year and we hope to top the list. There is an American lager beside ours so we should have some keen competition. Play centre forward on our football team \& have a few scores to my credit." 293 In larger camps, as Miller attested to in this last letter home, sports became increasingly organized, with serious attempts to recreate the sporting atmosphere of home within

\footnotetext{
${ }^{291}$ Munro Fraser, "Prisoner of War Life," in Prisoners of the Reich: Germany's Captives, 1939-1945, ed. David Rolf (London: Cooper, 1988), 88. Miller mentioned 'rugby' in three of the letters he sent home in 1943 and in one note send during 1944; 'cricket; appeared only once in a letter sent home in the summer of 1943. These references in the correspondence Miller sent home, were intended to inform his parents of the numerous sports available to their son during his imprisonment, but unlike his notes home about actually playing basketball, the same was not said about rugby and cricket.

${ }^{292}$ Erle Miller to Gladys Miller, 5 July 1943.

${ }^{293}$ Erle Miller to Gladys Miller, 2 April 1944.
} 
the camp environments. ${ }^{294}$ These team dynamics also presented a coping mechanism for prisoners who were forced to endure the monotony of camp life; it was one that Miller had not had the opportunity, nor (it appears) the desire, to experience in his previous POW camps. Given his physically weakened state at both Dulag Luft and Stalag VIIIB, Miller had little energy for anything more than the basic daily routines. ${ }^{295}$

During the winter months of 1944 , when the weather was sufficiently cold, skating rinks were constructed by inmates and hockey games were played by internees, especially the Canadians. ${ }^{296}$ Letters sent home from behind barbed wire during this period were not filled with book requests, as were those sent from Stalag Luft III, but, rather, clearly illustrate Miller's focus on physical leisure activities. With hockey in mind, Miller began to request that a skate parcel be sent to him from home as early as $5 \mathrm{June} 1943 .{ }^{297}$ Naturally, hockey competitions and leagues arose out of such barrack dynamics, with tournaments being organized through these units, and Canadians dominating the play. ${ }^{298}$ Miller's correspondence home during the winter months of 1943-1944 indicates, however, that his hockey career was very short lived at Stalag VI on account of inclement weather: "The lowest the weather has been so far was 10 degrees below.

\footnotetext{
${ }^{294}$ In British camps, this took the form of competitions between the British home nations and the Commonwealth, while other camps, such as Stalag IIB promoted the "age-old feud between North and South[...] the Rebels and the Yanks." Gilbert, POW, 163. Prisoner of War Bulletin, 3, no. 3 (March 1945): 2.

${ }^{295}$ While Miller does not state this directly in his letters home, it can be inferred through his notations in his journal which portray an emotionally exhausted and physically weak and malnourished captive. In light of his physical health and mental health, reading had served as Miller's preferred leisure activity during this period of imprisonment.

${ }^{296}$ Mackenzie, The Colditz Myth, 201.The construction of hockey rinks took a considerable amount of time as POWs would first build low dikes of sand, or snow around the playing area, which would be graded, or leveled, with homemade shovels. Water could then be added in from the fire pool, which was sometimes pumped, but in most instances was carried, bucket by bucket. After hours of work, an ice surface of an inch think could be established. John Dreiford, “Anything but Ordinary: POW Sports in a Barbed Wire World," Journal of Sports History (Fall 2007), 425.

${ }^{297}$ Erle Miller to Gladys Miller, 5 June 1943. "Dear Mother \& Dad - Health O.K. \& hope you are the same. We're to be moved to a new camp shortly. Will you send my skates? Have no news." Miller received his skates on 24 October 1943, and wrote home that, "I'm receiving very little mail from you recently but have received my skate parcel and 8th personal which are both very nice.[...] The skates fit perfectly, thanks a lot." Erle Miller to Gladys Miller, 24 October 1943.

${ }^{298}$ Dancocks, In Enemy Hand, 101-102.
} 
Had one morning playing hockey."299 By 1 February, Miller wrote home that, "The skating is finished here now \& everything is dried up." 300

The summer of 1944 and the Red Army's advance into the Baltic states, initiated the response of German officials to evacuate Stalag Luft VI at Heydekrug and, subsequently, to disperse 425 Canadians from this camp to Stalag 357 at Thorn, in Poland. ${ }^{301}$ In mid-July, Miller was part of a second wave of inmates moved from Heydekrug to Thom, a camp that comprised a central fortress, surrounded by satellite forts that housed prisoners. ${ }^{302}$ Unfortunately, the Collection does not account for Miller's month at Thorn as his last piece of correspondence was dated 23 June 1944, and his writings in his second journal did not begin until September of that year. ${ }^{303}$ During this period, however, the evacuation of Allied forces continued as the Russians fought their way into central Germany. ${ }^{304}$ Instead of permitting the liberation of the Heydekrug POWs during this time, the Germans moved them from Thorn to Fallingbostel. Miller was part of this second displacement, and left Thom on 10 August 1944 for Fallingbostel, or as he referred to it in his journal, "Starvation Camp.",305

\footnotetext{
${ }^{299}$ Erle Miller to Gladys Miller, 20 January1944. Miller had attempted to play hockey at Stalag Luft III, as he and fellow POWs had set up a hockey rink. Unfortunately, an early spring thaw put an end to this sporting initiative. The same happened in the winter of 1944. Miller wrote home that, "The skating is finished here. We had two days of it and the thaw set in. The lowest the weather has been so far was 10 degrees below. Had one morning playing hockey." Erle Miller to Gladys Miller, 20 January 1944.

${ }^{300}$ Erle Miller to Gladys Miller, 1 February 1944.

${ }^{301}$ This period also saw the transfer of 175 Canadians to Stalag Luft IVB at Muhlberg. Lagrandeur, We Flew, We Fell, We Lived, 164.

${ }^{302}$ The first purge of POWs to Thorn had consisted of 1200 inmates traveling via rail, and Miller followed, alongside 1500 NCOs a few weeks later. In November 1944, the last columns of POWs left Stalag Luft VI for Stalag XIB at Fallingbostel, north of Hanover. Miller would be sent to this camp in August of 1944. Lagrandeur, We Flew, We Fell, We Lived, 160.

${ }^{303}$ This last letter read, "Dear Mother \& Dad - Mail pretty slow these days. Just finished a very good book which I think you'd enjoy "This Above All" by Eric Knight. The weather is pretty good these days and have quite a suntan. Am doing a bit of studying on salesmanship lately. Am told that those sketches have been received by some of the people back home. Have you received mine? It's far from flattering. Loads Love - Erle." Erle Miller to Gladys Miller, 23 June 1944.

${ }^{304}$ For more information on the Red Army's advance into Germany please see Tom Bower, Heroes of World War II (London: Boxtree, 1955), 18 - 24, and John Nichol and Tony Rennell, The Last Escape: The Untold Story of Allied Prisoners of War in Europe, 1944-45 (London: Viking, 2002).

${ }^{305}$ Miller, POW Journal, v.2.
} 
Fallingbostel earned this reputation because of chronic ration shortages that devastated internees throughout the last 10 months of the war. While limited food, in terms of its quality and quantity, was a constant in the lives of prisoners of war, Miller's journal provides startlingly insight into his diet, and its effect on his emotional and physical well-being at this camp. ${ }^{306}$ The following is Miller's entry from 15 March 1945, which read:

Morning: Parade: lovely weather. Bags of rumors[sic] but nothing authentic. Made several circuits and came in exhausted. Have very little energy. Couldn't sleep last night because of thinking of food. Pillow wet from drooling in my sleep. Sat out in sun all morning. Afternoon: Dinner soup-swede very watery. Sat in the sun all afternoon. Very big air raid on. Had a slice at $2: 30$. Soup up at 4 worse than noon. Grub very low. Have no fags left. Parade and then circuited till 6:45.

Evening: Had slice. No lights on. Went to bed. ${ }^{307}$

What is apparent through this entry is the central place that food had in Miller's daily routine. Not only did he incorporate it into his journal as a means of dividing up the day, as demonstrated in the above passage, but thinking about food also consumed much of Miller's time. The latter is apparent in his journal as, on 20 different pages, he drew various food items, such as fried eggs, pork chops, cans of coffee, jars of peanut butter and bars of chocolate. These drawings reflect items that Miller would have received in Canadian and American Red Cross parcels, as well as those he missed from behind barbed wire, such as pork chops and eggs. Miller also made a

\footnotetext{
${ }^{306}$ While Miller had spent the better part of his captivity at two reputable prisoner of war camps, with relatively good food stocks, there had always been just enough food to go around. To the other extreme, during his four year as a prisoner of war, had experienced chronic malnutrition and near starvation at both Stalag VIIIB and Stalag XIB. ${ }^{307}$ Miller, POW Journal, v.2, 15 March 1945. Miller began every 'afternoon' entry with a brief description of what he had had for lunch that day. In most cases, it was a piece of toast and soup. In his 3 March 1945 entry, Miller wrote, "Dinner: Same as yesterday, only a bit more water added." Soup was a constant in Miller's diet, and as a result of the limited quantity he received, and its low nutritional value, Miller began to lose a noticeable amount of weight (just as he had done at Stalag VIIIB). He noted in his journal that, "feeling very weak today. Lost a lot of weight." The malnutrition that Miller experienced at Fallingbostel was the worst abuse he had to endure throughout his captivity as a POW.
} 
detailed list of different foods and meals, both suppers and deserts, which he titled, "Foods I'll Eat To Excess When I Return," and included the following: ${ }^{308}$

\author{
Eggs \& Bacon \\ Steaks with Onions \\ Sausages \& eggs \& toast \\ Lamb, viel[sic] \& pork \& yorkshire pudding \\ Corn, cheese \\ Fresh fruit and toast \\ Macaroni \& cheese \\ Toasted ham sandwich \\ Lamb \& dumplings \\ Corn beef \& cabbage with lots of butter \\ French toast with poached eggs \\ Mock willie (steak and bacon) \\ Steak \& kidney pie \\ Corn beef, hash \& eggs \& butter \\ Sausages, $\&$ beans with eggs \\ Steak with eggs on top \\ Chicken, roast spuds \& corn \\ Rich choc. malted milks \\ Ice cream \& nuts \\ Porridge with cream \& sugar \\ Peanut butter \& honey \\ Strawberry choc. cake \\ Apple fried with ice cream \\ Hot blueberry pie \\ Cream pie with ice cream \\ Banana pie with ice cream \\ Lemon shevel[sic] with ice cream \\ Date pie with ice cream \\ Rice pud. with cream \\ Pumpkin pie with whipped cream \\ Hot blueberry pie with whipped cream. ${ }^{309}$
}

During this period of Miller's incarceration, the war in Europe moved into its final stages as the western and eastern Allies prepared for their respective final drives into Germany. In December 1944, Germany had made a final desperate gamble for victory by launching an armoured attack in the Ardennes in an attempt to break through the American lines and cut off

\footnotetext{
${ }^{308}$ Miller, POW Journal, v.2, 29 February 1945.

${ }^{309}$ Miller, POW Journal, v.2, 29 February 1945.
} 
the Canadians and British forces to the north. The attack failed, however, and by mid-January it was apparent that the Germans would be defeated. It was roughly during this same period that the Soviets resumed their offensive on the Eastern Front, capturing Warsaw on 17 January 1945 and making for Germany. ${ }^{310}$

Germany began evacuating its prison camps and forcing inmates to march westward across Germany and away from the approaching Soviets forces. POW camps in central Germany, following the evacuation of camps in the east from December 1944 onward, became increasingly overcrowded. By the very end of the war, they had doubled or even trippled in size, with sports areas and parade grounds replaced by vast canvas encampments to house incoming prisoners. ${ }^{311}$ Close quarters were worsened by a lack of food and fuel which made living conditions intolerable. Prisoners also had to contend with the increasing intensity of the Allied strategic bombing campaign, which was particularly active in the metropolitan and surrounding area near Fallingbostel, as Hanover was in close proximity to this site. ${ }^{312}$ Miller's journal contains nine different entries referring to separate bombing raids which took place within earshot of this Stalag. On 9 December 1944, for example, Miller simply noted, "Air Raid on.”313

In January 1945, the Luftwaffe began to evacuate air force POWs from Fallingbostel, Lamsdorf, Bankau, Sagan and Belaria. ${ }^{314}$ While rumours of forced marches circulated for weeks in some camps, Miller's journal indicates that he was officially given notice to be ready to evacuate a day before he was ordered to leave Fallingbostel. ${ }^{315}$ This journal entry, from 7 April

\footnotetext{
${ }^{310}$ For an introduction to the events and history of 1945 in Europe, see Charles Brower, ed. World War II in Europe: The Final Year (New York: St. Martin's Press, 1998).

${ }_{311}$ Mackenzie, The Colditz Myth, 364.

${ }^{312}$ Ibid.

${ }^{313}$ Miller, POW Journal, v.2, 9 December 1944.

${ }^{314}$ Gilbert, POW, 314.

${ }^{315}$ Miller, POW Journal, v.2, 7 April 1945. In most cases, POWs were given only a few hours to prepare before their camps were evacuated. Lagrandeur, We Flew, We Fell, We Lived, 370. Warrant Officer Harold White was also at Fallingbostel at this time, and in recalling the beginning of his forced march, noted: "On April 9, they moved us out
} 
1945 reads, "Dull day. Told to be ready to evacuate camp to-day. Issued with 1/8 of a mediocre parcel." In the afternoon of the $7^{\text {th }}$, Miller added that, "We are packed ready to leave but party was turned back to camp. Very obitimist[sic] about staying." ${ }^{316}$ Two days later, however, at approximately 1:30p.m., Miller's forced march began. ${ }^{317}$

Miller's prisoner of war journal contains not only a chronological list of towns he marched through from 9 April 1945, until his liberation on 2 May 1945, but he also continued to write his daily entries during this arduous period. As such, Miller's prisoner of war journal offers a relatively full account of his last month of incarceration, which was the most difficult thing he experienced throughout his Second World War service. Prisoners were forced to march regardless of their poor physical condition and many suffered, as Miller did, from malnutrition and were in no physical shape for the strenuous journey ahead. ${ }^{318}$ On 9 April 1945, Miller walked from Fallingbostel to Ilster, a distance of $32.8 \mathrm{~km}$, and noted in his journal that their accommodations for the night was a farm, which was "very small. About 200 of us \& all crammed in small barn. Had slice \& brew \& went to bed sitting up, not room to be down. When needed a urinal just did where sitting as impossible to get out." ${ }^{319}$ After a day at this site, Miller walked $33.2 \mathrm{~km}$ to Hanstedt. In three days Miller walked a total of $65 \mathrm{~km}$. His mood and stamina

of the camp. We had to pack everything, any food we had, clothing, bedding, we had to pack the whole thing. By that time we were getting so undernourished and suffering from malnutrition that when I went to bed at night, I felt like I didn't know if I would wake up in the morning. Then to go packing a load was a real strain on you." Warrant Officer Harold White in Dancocks, In Enemy Hand, 203.

${ }^{316}$ Miller, POW Journal, v.2, 7 April 1945.

${ }^{317}$ Miller, POW Journal, v.2, 8 April 1945. Miller's entry on this day read, "Started to march up 1:30. 1 hour march $\& 10 \mathrm{~min}$ rest. march till about 5 and came to our destination. Split into groups of about 2 or 3 hundred $\&$ huddled in barns."

${ }^{318}$ A fellow airman who was marched from Fallingbostel in April 1945, recalled, "And so we walked the last month like this. That was terrible, because everybody was sick and weakened, most of them by less food and less food. Because the Red Cross could not get to us as easily as previously." Sergeant Gilles Lamontagne in Dancocks, In Enemy Hand, 203. Those prisoners, however, who were ill or incapable of marching, were left behind to be overrun by the advancing Red Army. The Russians showed great compassion for the disabled and sick RAF and Dominion air forces POWs, offering the prisoners food and medical attention. Lagrandeur, We Flew, We Fell, We Lived, 375. ${ }^{319}$ Miller, POW Journal, v.2, 9 April 1945. "Map of Germany with Cities and States," World Atlas Book, accessed 24 July 2012, http://www.worldatlasbook.com/germany/germany-political-map.html. 
were quickly deteriorating; he noted in his journal: "Long grind. Pissed off. Have dose of dysentery and very weak \& hungry." ${ }^{320}$ The following day, Miller was marched to Rehlingen, which, at a distance of $25.8 \mathrm{~km}$ from Hanstedt, and his entry from this day, read:

Morning: Up 1. Got a fire going \& boiled up some spuds \& chicken feed. Started march at 10 . Grueling going. Hungry \& weak as hell \& a lot of dysentry[sic].

Afternoon: About 1:30 had tin of sardines on bread. Marched steady with occasional break. Did about $17 \mathrm{Km}$. 25 from Lunebarg[sic]. Think our destination somewhere near there.

Evening: Arrived here at farmers at 6 . Very confined space for sleeping. Got fire going \& cooked some spuds and swede. I had a brew. No bread left. Forced into barn \& door closed. Not even sitting room. ${ }^{321}$

Miller's forced march continued on the 13 of April, with a $12.5 \mathrm{~km}$ trek to Barmstedt. As prisoners and captives travelled further from their last permanent camp, their provisions of food became increasingly low, and on this day, Miller's journal indicates that all he was given to eat was a piece of raw turnip and one $1 \mathrm{lb}$. potato. ${ }^{322}$ Such dietary conditions quickly took their toll on the young airman, and Miller wrote on the morning of 14 April 1945, before departing for Deutsch Evern: "Very ill this morning. No food. Had some spuds we managed to scrounge \& some swede. ${ }^{323}$

While the prisoners did not know where they were headed, Miller noted the signage on the way to Wendisch Evern, which provided him with a general bearing: "Rumor $11 \mathrm{Km}$ to-day. Marched till 5:30. Sign post says Hamburg $66 \mathrm{Km}$ \& Luneburg $8 \mathrm{Km} .{ }^{324}$ Continuing on the 16

\footnotetext{
${ }^{320}$ Miller, POW Journal, v.2, 11 April 1945. In remembering forced march living conditions, Sergeant Jim Sampson noted, "They'd put us up in farms along the way. Well, we stole everything that was on the farm to eat. We killed the chickens and the pigs, ducks, anything that edible, we'd steal it. And so, before long they realized they couldn't keep doing this. So they started just leaving us out in the fields." Sergeant Jim Sampson in Dancocks, In Enemy Hand, 203.

${ }^{321}$ Miller, POW Journal, v.2, 12 April 1945.

${ }^{322}$ Miller, POW Journal, v.2, 13 April 1945.

${ }^{323}$ Miller, POW Journal, v.2, 14 April 1945. In his evening entry, Miller reported in his journal that he was "Very hungry \& weak."

${ }^{324}$ Miller, POW Journal, v.2, 15 April 1945. The distance between Deutsch Evern and Wendish Evern is $9.4 \mathrm{~km}$.
} 
April, Miller walked to Luneburg, some 16 kilometres away. His journal entry from this day indicates that tensions between the Allied captives and German guards was becoming fairly aggressive: "Officers threatened with revolver." ${ }^{325}$ While Miller wrote little else on the subject, his entry from the following day, 17 April, indicates that this was the most arduous day of his march:

Afternoon: Arrived at our destination about 4:30. Worst day yet. Marched till ready to drop. Village filled \& we stayed in field. Got fire going. No issue except 4 spuds each. Had spuds \& brew.

Evening: Bedded down in field. Blankets soaked \& also great coat \& feet. Sat around in water till 11:30 \& were taken to Church \& crammed in. managed to get under pew \& get a little sleep. Very little. ${ }^{326}$

After a day's reprieve, Miller was on course to Beckdorf, which was roughly $14 \mathrm{~km}$ away from Norstorf. While marching columns were commonly moved through the countryside in order to avoid being caught in the bomber raids which had already devastated German cities, on 19 April 1945 Miller's journal entry indicates that he came under attack from Allied fire. His journal entry from this day contains the details of this traumatic event:

Up 5:30 left Church \& went to field. Made brew. Hell of a stomach ache. Started march 7:30. Doubled up with pains. Fell out sick \& M.O took my kit. Continued on march. Very sick. Arrived at village where we collected Red X American food parcel each. Had drive for $1 \mathrm{Km}$. When in open road were shot at by American Typoons. Lot of us killed \& wounded. Mackenzie killed. Around 50 killed \& same no. approx. wounded. Duffy killed. Boy it was a close call. Very nervous. Quite some disorder. Arrived at barn. Parties split. Had some prunes. Stomach little better. Had several coffee beans. Chaps buried in place called Hidekrug. Had bullet hole in coat. ${ }^{327}$

\footnotetext{
${ }^{325}$ Miller, POW Journal, v.2, 16 April 1945. The German guards during the forced marches of 1944/45 were generally helpful, allowing for extended halts of a day or more. There is evidence of this in Miller's force march experience as he had six of this sort of 'break' during his month of marching. Gilbert, POW, 302.

${ }^{326}$ Miller, POW Journal, v.2, 17 April 1945. Miller's march to Norstorf consisted of a $17.5 \mathrm{~km}$ trek.

${ }^{327}$ Miller, POW Journal, v.2, 19 April 1945. This, understandably, was a near-death event that Miller remembered long after the war, and it was a 'war story' that he shared with his wife, Cleta Miller (nee Barr). In recalling this event some 70 years later, Cleta noted: "Fortunately he had picked up a Russian Great coat on the March and when three British planes swept down, strafing them he ran with all his strength to dash behind the only tree in sight. The
} 
The following morning, Miller resumed his forced march and travelled 17 kilometres to Gudow. Sleeping quarters, at this point, were very poor, and Miller noted in his journal that he, "spent hell of a night lying in the rain." ${ }^{\text {328 }}$ His situation did not improve the following day, as Miller's journal reflects the discomfort he had to endure during his march to Tessin:

Morning: Raining this morning. Slept not too bad in uncompleted house. Boiled up brew \& fried spuds. No wash for 2 days. Soaking wet. Started to march about 9:30. Marched steady most of the day. Afternoon: About 12 we met a milk wagon \& got some milk. Rained in afternoon. Got soaking wet including blankets. Feeling horribly miserable. Arrived at village to find no accomodation[sic]. Got slice of bread from some Russians.

Evening: Proceeded to next village. Arrived about 5:30 at our barn. Soaked to skin with no nope of drying. Had some spuds \& a stew \& brew. Burroughed into straw after removing overcoat. Didn't move till morning. ${ }^{329}$

Miller remained at Tessin until the 25 April, when he was forced to march approximately 34 kilometers to Rognitz. Miller's health was deteriorating at this point, as he was not only physically exhausted from days of walking and disrupted sleep in confined spaces, but he was becoming increasingly malnourished. Miller remained at Rognitz until the 27 April, when prisoners were marched to Kittlitz. Fortunately for Miller, they remained in Kittlitz until 1 May. While he did not know it, his journal entry from this day foreshadowed the end of his forced march, and liberation:

Morning: Had couple sips of brew \& we managed to get into a barn. Slept for a few hours and then we had to prepare to march. Afternoon: marched to Albolfielde. Got in barn. Put on some peas. Had stew, peas \& a brew. Evening: Went to bed very early. Rumours boys are very close. ${ }^{330}$

bullets missed his splayed legs and went through the coat." Cleta Miller, Brockville, Ontario, to Emily Gann, Ottawa, Ontario, 3 July 2012.

${ }^{328}$ Miller, POW Journal, v.2, 20 April 1945

${ }^{329}$ Miller, POW Journal, v.2, 22 April 1945. Tessin is 24 kilometer away from Gudow.

${ }^{330}$ Miller, POW Journal, v.2, 1 May 1945. This day's march consisted of a 15 kilometer trek from Rognitz to Kittlitz. 
Miller was liberated by the advancing British Army on 2 May 1945. His four years as a prisoner of war and forced march of nearly 240 kilometers was over, but his journal reveals that his liberation, the very thing that had seemed impossible and remote, had left him in a state of disbelief. $^{331}$

Morning: Up at 6:30. Had brew. Great moment happened at 1:15 when boys drove up with M.P. Broke up German rifle \& officers surrendered. Was cooking egg when news came. In state of wonder. Afternoon: Commandeered horses \& we moved to place called Molln. Arrived about 7. Put in Nazi headquarters. Got lovely rifle. Put chicken on to broil \& porridge.

Evening: Had chicken, porridge \& brew \& went to bed. ${ }^{332}$

A month later, on 1 June 1945, Miller left England for Canada. His journal entry for that day read, "So long England. Will be back again sometime."333

331 Jack Bishop, another prisoner of war liberated near Lubeck, noted in his published memoir that, "it was surprising how calmly our liberation was received. There was a complete silence, as if the situation was beyond our comprehension." Jack Bishop, In Pursuit of Freedom, (London: Cooper, 1977), 123.

${ }^{332}$ Miller, POW Journal, v.2, 2 May 1945.

${ }^{333}$ Miller, POW Journal, v.2, 1 June 1945. 


\section{Chapter Three: Mother on the Home Front}

From Miller's departure for active service with the RCAF in August 1940 until his return to Canada in June 1945 , his mother, Gladys Miller, was his central link to his local community in Canada. This was an important relationship to Miller as his mother not only facilitated an emotional connection to family, but also acted as the primary conduit behind his receipt of goods and materials during his incarceration. Miller's efforts to sustain this bond are well documented in the 183 letters that were sent from son to mother during the Second World War. While only one of Gladys Miller's wartime letters survives, her correspondence with her son may be partially reconstructed through a thorough reading of his letters and responses to her. ${ }^{334}$ The content of Miller's notes suggests that the written connection he shared with his mother focused primarily on daily life and routine social interactions. While Miller's letters offer a great deal of insight into his new experiences overseas, they also prompt his mother to divulge information on a host of topics concerning the home front community. Within this dialogue, one can infer from the infrequency with which Miller repeated questions in his letters home that his mother was steadfast in her efforts to answer all of her son's queries in order to maintain his sense of connection to family and friends in Renfrew. ${ }^{335}$ Through her letters to her son, Gladys Miller provided a stabilizing link to the Canadian home front he had left in late August 1940.

\footnotetext{
${ }^{334}$ This letter, which has been examined in this thesis, was never received by Miller. While he undoubtedly had quite of collection of notes from his mother, it was difficult for prisoners of war to transport personal possessions with them during camp transfers. For this very reason, the fact that the Miller Collection contains his two prisoner of war journals is of particular note, as these are two very rare documents which were clearly valued by Miller.

${ }^{335}$ In a letter sent from Miller to his mother on 26 May 1941, he responded to her comments on the changes to their family home, writing "You're saying how you painted the kitchen. Would like to see it. Would sure like to stroll in there and raid the ice box. Drink about a galion of Milk 1/2 doz. eggs and plain toast. By the way we had an egg tonight for supper. Mine was an exceptionally large one. The hens must be putting forth the war effort." In the same letter, Miller also asked after his family and his father's business which were questions that he often repeated in his correspondence with his mother. Erle Miller to Gladys Miller, 26 May 1941. News of the family was incredibly important for servicemen's morale, according to Barbara Hately-Broad's study of British POW families. She writes,
} 
Gladys Miller was born on 17 October 1900 in Horton Township, Ontario. After marrying Donald Miller, the young couple moved to Beaver Lake, Alberta, where they had been offered free land for farming from Donald's family, the McCallisters. Erle was born in 1920, and the following year, Gladys and Donald had their second son, Ronald. At 11 months, however, Ronald died tragically and Gladys, in need of support, moved with her son and husband to Castleford, Ontario, where she had family. Leaving their farming life behind in Alberta, Donald bought a store and became the resident Postmaster for their new town. The following year the family welcomed a baby girl, Margaret Miller, into the world. The four lived together in the Ottawa Valley until Miller's departure for war in 1940, and Margaret's move to Ottawa for work in 1941. A connection and closeness with family was important to Gladys and one might surmise that her second son's passing reinforced her instinctual desire to protect and provide for Miller.

Family, specifically the relationship between mother and son, is at the core of the Miller Collection. There is, however, very little scholarship which discusses the roles of mothers (of servicemen overseas) on the Canadian home front during the Second World War. Where women in this role are mentioned, however, is typically in opposition to the heroic image of women who served during the Second World War. ${ }^{336}$ What is clear through the family's collection of letters is that mothers in Canada were very active in providing for their sons overseas, and through such efforts became part of various home front communities dedicated to this cause. These communities promoted a sense of familiarity, and trust for women, like Gladys Miller, who had

\footnotetext{
"As one wartime Army Morale Report reported, 'If his family is happy, he has something to fight for: if his family is in distress he cannot give his whole mind and heart to his soldiering.' Report of the War Office Morale Committee November 1943 to January 1944. NA/WO32/15772/15772 quoted in Barbara Hately-Broad, War and Welfare: British POW Families, 1939-1945 (Manchester: Manchester University Press, 2009), 3.

${ }^{336}$ Such heroism was constructed through a woman's freedom to serve her country, which "was the result of her not being what a woman was expected to become, a wife and mother.[...] Women who came into these categories were not expected to be available for war work in the unconditional way in which young single women were: the housewife and mother must remain the 'cornerstone' of the home and hence the nation." Penny Summerfield, Reconstructing Women's Wartime Lives: Discourse and Subjectivity in Oral Histories and the Second World War (New York: Manchester University Press, 1998), 80.
} 
Canadian sons in prisoner of war camps overseas. By sharing in this period of upheaval, these women provided one another with a sense of security, support, and most importantly, comfort during a period of great anxiety and stress. For Gladys, these networks were presented in the connections she had with family, friends, mothers of other airmen, as well as mothers of prisoners of war. The Miller Collection also indicates that Gladys, as a mother of a POW, was also assisted by the larger networks available to individuals and families in similar situations, such as the Canadian Red Cross Society. While the latter may not have provided the same level of emotional comfort for Gladys as was offered to her in the letters sent from family and friends, it was through such organizations that she was able to send goods to her son. In this capacity, these systems of provision reassured Gladys that her son was being provided for behind barbed wired. While these two distinct types of communities provided different types of support for Gladys, they were both central to her ability to provide for her son behind barbed wire.

Once her son became a prisoner of war, Gladys's position as a mother on the home front became doubly vital to his wellbeing. Though her letters continued to supply Miller with an attachment to his home life, it was the actions that Gladys took to send goods, such as food, recreational, and personal parcels, that had greatest influence in sustaining her son's mental and physical health behind barbed wire. The 117 letters Gladys Miller received between 12 September 1941 and 12 April 1943 from family, friends, community members, and prisoner of war related organizations at the local, national and international level, suggest that Miller's mother became his home front ambassador during his incarceration. These networks provided not only a community of comfort, but also, as this chapter will show, they offered Gladys Miller, a mother in rural Canada, access to various forms of aid, which she used to assist her son. While the Miller Collection suggests that Gladys was a woman of great courage and personal resolve, it 
also indicates that, during her family's darkest hour, she was able to seek solace in the written words and existing networks of her community. ${ }^{337}$

Prior to his capture on 8 September 1941, Miller's service training and relative social freedom provided him with a wide variety of stories to write home about, many of which have been highlighted in this thesis. His early letters served as connections to those he missed in Castleford but, more than sentimental tokens, they also informed his mother of her son's needs. Parts of his letters, in fact, acted as veritable shopping lists for Gladys on the home front, especially for goods and materials which Miller could not readily acquire in Britain. For the most part, he requested cigarettes, meats and articles of clothing that were too expensive to purchase in the towns nearby the RAF stations where he was posted. These requests were diligently met by his mother and, as a result, Miller acquired everything he asked for, save items that, as he put it in a letter dated 12 March 1941, "fed the fishes."338

On 9 September 1941, the Miller family received a telegraph sent by the Air Ministry Records, which informed them that, "your son CAN R 53900 Sergeant Erle Sinclair Miller is missing as the result of air operations on 7th Sept 1941. Miss Miller [Margaret] Castleford also informed. Letter will follow."339 The following day the Miller family received a letter from Wing Commander P. Beauchamp of "C" Unit, RAF Station Waddington, which described in great detail the events of their son's last operation:

\footnotetext{
${ }^{337}$ Judy Barrett Litoff and David Smith observe that "The news that loved ones were prisoners-of-war, missing in action, or killed during battle required women to draw on a previously urttapped inner strength." Judy Barrett and David Smith, "US Women on the Home Front in World War II," Historian (December 1995), 357.

${ }^{338}$ Erle Miller to Gladys Miller, 12 March 1941. This quote was a subtle reference to the perils of the Battle of the Atlantic which, by the Spring of 1941 , was not progressing well for the Allies.

${ }^{339}$ Air Ministry Records. Telegram from RAF Innsworth, Gloucester, UK, to Donald Miller, Castleford, Ontario, 9 September 1941. Two days later, the Millers received the promised letter which read, "Sir, I am commanded by the Air Council to express to you their regret on learning from the Casualties Officer of the Royal Canadian Air Force that your son, Sergeant Erle Sinclair MILLER is missing. The Air Council desire me to express their deep sympathy with you in your great anxiety, and earnestly hope that favourable news of your son may be forthcoming." Letter from RAF Inns worth, Gloucester, UK, to Castleford, 11 September 1941.
} 
I have to refer to the sad news conveyed to you by the Air Ministry that your Son[sic] is missing as the result of air operations on the night of 7/8th September, 1941.

The aircraft of which he was the Air Gunner failed to return from a mission over enemy territory. It was one of a number of aircraft which were detailed to attack targets in Berlin. The aircraft left the aerodrome here at 9.20 p.m., on the 7th September, and was scheduled to carry out a high level attack on its target at approximately 1.10a.m. Messages received from the aircraft indicate that it was attacked by fighters and damaged some distance from the target and there is every likelihood that the crew bailed out.

The Captain of the aircraft was a very able and experienced pilot and I am fully convinced that he would do everything in his power for the safety of his crew. It is the fervent desire of everyone in the Squadron that your son, who was held in very high esteem, is safe, and I sincerely hope that I will receive news confirming this.[...] Your son's personal effects are being sent to the Officer Commanding, Central Depository, R.A.F., Colnbrook, Slough, Bucks., in accordance with regulations and that Officer will be communicating with you in due course regarding their disposal. ${ }^{340}$

What followed was a period of extreme anxiety for the Millers as they awaited word of their son. The Miller family shared their unfortunate news with the Ottawa Valley community in the 11 September edition of the Renfrew Mercury, four days after their son had been shot down. On the paper's fourth page, the Miller family's uncertainty became local news in a short article that began: "The sympathy of the community goes out to Mr. and Mrs. Donald Miller and Miss Margaret, who have received official word that their son, Sgt. Erle Miller is reported missing."341 Through this article, the Miller family shared news about their son with the Ottawa Valley readership, and in this way, made their private uncertainty and grief known to the local community.

\footnotetext{
${ }^{340}$ Wing Commander Beauchamp, Lincoln, UK, to Donald Miller, Castleford, Ontario, 10 September 1941.

${ }^{341}$ Renfrew Mercury, 11 September 1941. Many of the letters from this period mention Miller's 'missing in action status', but there is only one letter that references the Renfrew Mercury directly. This one was from North Bay. It announced: "My constant hope, and daily prayers are that before long you will receive news of dear Erle's safety. Erle is such a dear boy. They all loved him at home, and it goes without saying, that I had a sisterly love for him. I read in the Mercury where Grandma Smith was with you. I know how heavy her heart will be, and yet she will be such a comfort to you all." Ileen, North Bay, Ontario, to Gladys Miller, Castleford, Ontario, 25 September 1941.
} 
The following week, Miller's story was on the front page of the Renfrew Mercury. In a photo-article Miller's picture appeared beneath a title that announced, "Renfrew Boy Reported Missing." ${ }^{342}$ This piece, which highlighted the uncertainty surrounding the life of a young, local boy overseas, was the first article of its kind to be published in the Renfrew Mercury:

Srgt. Gunner Erle Miller, son to Mr. and Mrs. Donald Miller of Castleford, reported missing, is a Renfrew boy of 21 years of age. He was born at Beaver Lake, Alberta, but removed with his parents to Renfrew when he was three years of age. He obtained his education in Renfrew Public school and R.C.I., and the Drummond College. He was a member of the Baptist church and for two year prior to going into the R.C.A.F. clerked in the Russell Drug store. He has one sister, Margaret. The family have not yet received further word. ${ }^{343}$

The Millers received a series of letters from their family offering immediate support. The following sympathetic and heartfelt letter dated 12 September 1941 from Gladys's cousin, Agnes, appears to be the first note of this kind, and is representative of the correspondence the Millers welcomed from members of their extended family during this initial period of upheaval:

Somehow, I do not believe that Erle is gone. I feel, (if my intuitive feelings mean anything at all) that you will have a message saying he has been taken prisoner or possibly in hospital. I know you will be afraid to build up too great hope, but I do not believe it is final. The waiting word is going to be awful, and I understand it is sometimes two, three, weeks or even a month. ${ }^{344}$

${ }^{342}$ Renfrew Mercury, 18 September 1941

${ }^{343}$ Renfrew Mercury. 18 September 1941 . Gladys received a letter on 20 September from Viola Cabb which spoke directly to this article published in the Renfrew Mercury and read, "In the anxiety you and your family are experiencing over your son's whereabouts, as reported in the newspaper, may we extend to you our deepest feeling, and trust, ere long, you will be happily relieved by good news. Viola Cabb, Arnprior, Ontario, to Gladys Miller, Castleford, Ontario, 20 September 1941.

${ }^{344}$ Agnes B., Toronto, Ontario, to Gladys Miller, Castleford, Ontario, 12 September 1941. (Several letters in the Miller Collection do not include the sender's last name. While referring to a community of a different context, Penny Summerfield's work in Reconstructing Women's Wartime Lives suggests that women factory workers shared this same kind of community of comfort, and many understood their co-workers as a family unit. In her analysis, she argues, "Women described sharing not only pleasures but also griefs and anxieties. Nearly half of all women in civilian work in wartime were married, a much higher figure than in peacetime. The young women in the sample remember supportive talk in breaktimes about families. (...) In these constructions, the personal and particular family of each worker was given discursive space within the larger 'family' constituted by the workers in the factory or office. A caring and mutually supportive wartime unity was the remembered outcome of the interaction between these families." Summerfield, Reconstructing Women's Wartime Lives, 169-170. 
The tone and the tenor of Agnes's letter was in keeping with the 20 notes of reassurance the Millers received from friends and community members that knew that Erle Miller was "missing in action". While many correspondents contacted the Miller family immediately, there were others who delayed in sending their words of concern. Such was the case for Gladys's cousin, Katie Huckabone, who wrote on 22 September 1941:

Was shocked to hear of Earle being missing and delayed writing as I thought from day to day word might arrive, however you may still hear and sometimes it is so long. It is such an anxious time for you all, the strain and suspense of wondering about him. My thoughts and prayers are with you these trying times, and trust you may hear yet about him. ${ }^{345}$

While this note, and seven others in the Miller Collection, acknowledged the uncertainty of the Miller family's situation, four additional letters urged Gladys to be brave in the face of her son's unknown fate. This theme first appeared in the correspondence that Gladys received from a fellow female member of the local community on 12 September 1941: "Try to be brave dear and live in hopes he may come home some day. Thousands of mothers are feeling the same way these days and it certainly is hard to take. Life does not seem to be worth living now it's all so full of dissapointment, heartache and very few pleasures."346

Gladys also received letters from three women who also had sons or nephews serving in the Royal Canadian Air Force. The first was sent from Bella Maville, the mother of Miller's

\footnotetext{
${ }^{345}$ Katie Huckabone to Gladys Miller, 22 September 1941. Lydia Odessa wrote in her letter dated 11 September 1941: "I don't know what to say, Gladys. Perhaps if we all pray that he is still alright it may turn out that he is." Lydia Odessa, Arnprior, Ontario, to Gladys Miller, Castleford, Ontario, 11 September 1941.

${ }^{346}$ Estelle to Gladys Miller, Ottawa, Ontario to Castleford, Ontario, 12 September 1941. Another letter in the Miller Collection encouraging Gladys to be brave read: "If he is taken, he fell in a noble cause and will get his reward. I must close - be brave - I know you will." Belle Lechie to Gladys Miller, Maniwaki, Quebec to Castleford, Ontario, 15 September 1941
} 
close friend, Red Maville, from No. 400 Squadron who had been killed in action in June $1941 .^{347}$

"We can fully understand," Bella Maville wrote, "how terrible you feel about your Dear Erle

only a Mother who has lost a dear son in such a way may know what sorrow such news brings

and one thinks so many different things but if the cable only said missing, I hope and trust to

God that you will get good news of your boy real soon."348 While Bella's words offered comfort

to Gladys, she also presented her with a community of support from one who shared in this type

of emotional toil.

The communal grief was expressed in another letter from Catherine McCallum, a friend of Gladys's from Beaver Lake, Alberta, Miller's birthplace, and the mother of a serviceman who had been killed in action on the 4 September $1941 .^{349}$ This letter, the shortest of the three pieces of correspondence, shares in the sympathy and comfort expressed in the other two letters:

I really feel I must write to you and tell you how sorry I was to hear that Erle was missing. I can just imagine how you felt. It would be a relief to hear that he was alive even though he is a prisoner of war. While there is life there is hope. It certainly is a pretty bad place to be but you will not need to worry about him being shot down again. I have read that the Germans do not treat their British prisoners so badly either because the British have lots of their prisoners and could even the score. ${ }^{350}$

Catherine's letter also acknowledged the sympathy shown her by Gladys in her own moment of need: "I received your card," wrote Catherine, "and thank you for your kind expression of sympathy. These unhappy times I realize what good hearts people have. It is the only thing that

\footnotetext{
${ }^{347}$ Red was killed on 22 June 1941 by friendly fire and is buried at Lincoln (Newport) Cemetery. "Casualty Details," CWGC, accessed 15 July 2012, http://www.cwgc.org/search-for-wardead/casualty/2358645/MAVILLE,\%20JOHN\%20ALLAN.See also Kirby, Avro Manchester, 79.

${ }^{348}$ Bella Maville, Ottawa, Ontario, to Gladys Miller, Castleford, Ontario, 11 September 1941. On 13 October 1941, Bella Maville sent a letter to Gladys which read: "In answer to your letter of September 28th, we were all happy to know you had good news of Earl for sure is great to know he lives. I hope someday he will return." Bella Maville to Gladys Miller, 13 October 1941.

${ }^{349}$ Brian McCallum was buried in Mundare Cemetary, in Beaver Lake, Alberta. Canadian War Graves Commission, Brian Allan McCallum, accessed 31 October 2012, http://www.cwgc.org/find-wardead/casualty/2850205/McCALLUM,\%20BRIAN\%20ALLAN.

${ }^{350}$ Catherine McCallum, Mundare, Alberta, to Gladys Miller, Castleford, Ontario, 26 September 1941.
} 
helps but two blows so close together is almost too much. But I guess a soldiers mother has to be a soldier too and carry on even when their best companions go down. ${ }^{351}$ A similar expression of connection and understanding was echoed in a letter Gladys received from Mary McLaughlin, the aunt of another one of the seven boys who enlisted in Ottawa in May 1940. Knowing that their boys had served together, Mary offered to the following words of comfort to Gladys:

I have a nephew in the Air Force Overseas who was with your son when they left Ottawa in August 1940, and I did want you to know that I was thinking of you. There is always hope he may turn up some where and I sincerely trust you may have further news soon. My nephew, William (Billy) McLaughlin of 22 Grove Ave, Ottawa, was with your son in England for a time but Billy has been moved about from one squadron to another and is now in R.A.F. as a night fighter. ${ }^{352}$

After a little over two weeks, the Millers' worries were calmed as they received word that their son was a prisoner of war. It was through the same home front community network that had provided such support when news first broke of Miller's 'missing-in-action' status, that they were made aware of his incarceration. A telegraph was sent to the family on 26 September 1941, indicating Miller's status, but rather extraordinarily the Millers had already been informed of their son's capture from Gladys's cousin, Agnes. ${ }^{353}$ As a resident of Toronto, she had come across a report four days earlier in the Toronto Daily Star, which announced, “Among [...]

\footnotetext{
${ }^{351}$ Ibid.

${ }^{352}$ Mary McLaughlin, Ottawa, Ontario, to Gladys Miller, Castleford, Ontario, 23 September 1941. Gladys would have known of Mrs. McLaughlin's nephew as her son had written about William, or 'Smoky', on three different occasions during his active service with the RCAF from 26 August 1940 to 7 September 1941. In these letters, Miller described Smoky as "quite smart - lot initiative, dam mischievous[sic] and always talks way out." Erle Miller to Gladys Miller, 15 March 1941. In a letter dated 28 May 1941, Miller wrote to his mother that, "Heard that Smoky McLaughlin was killed in a Lysander crash but its not official and I think its just a rumor." Erle Miller to Gladys Miller, 28 May 1941. A few days later, Miller informed his mother that, "When I got back [from dinner] there was a note on my bed from Smokey McLacklin saying he wasn't dead. He was on leave so dropped in to see me. Was sure glad to hear from him." Erle Miller to Gladys Miller, 31 May 1941.

${ }^{553}$ Occasionally the news of a POW's status travelled to relatives more quickly through unofficial channels. David Rolf's work on prisoners during the Second World War highlights the example of Private Bowers, who, after being captured in Belgium in the summer of 1940, was able to pass a handwritten message to a Red Cross nurse, which was then forwarded to his mother long before she received official notification that he was missing. David Rolf, "Blind Bureaucracy," in Prisoners of War and their Captors in World War II, ed. Bob Moore and K. Fedorowich (Washington, D.C.: Berg, 1996), 50.
} 
seven Canadian airmen reported prisoners of war was Pilot Officer William Geoffrey Peat, Fort William. The others were Sergt. James Alexander Smith, Winnipeg: Sergt. Thomas Victor Johnson, Saskatoon: Sergt. Earl Sinclair Miller, Castleford, Ont: Sergt Ronald Bruce McCloud, Saskatoon. ${ }^{\text {354 }}$ This was not the only newspaper article about Miller's experience, as in her scrapbook, Gladys collected two other pieces concerning her son's experience. The first was a story in the Globe and Mail on 30 September 1941, which listed eight Canadians previously reported as missing, but who were now named prisoners of war. ${ }^{355}$ Miller's brief mention in this article read, "Miller, Erle Sinclair, Sergeant, Can.R53900, prisoner. Mrs. D. Miller (mother), Castleford, Ontario."356 The article also included the names and mailing addresses of the six other mothers and the one wife of the servicemen mentioned. While the Miller Collection does not contain any letters from these families, the newspaper suggested to its readership that these women were the points of contact for these eight prisoners of war. ${ }^{357}$ The paper thus offered a gendered appreciation of the relationship that mothers (specifically) had to their prisoner sons, which is never directly stated in the Miller Collection. It is quite apparent, however, that Gladys had been accorded this central role as primary contact and that she accepted her part: all 183 personal letters which have survived from this period are addressed to Gladys Miller. ${ }^{358}$ Gladys was not only sent this concerned correspondence, which amounted to 40 letters in 1941 alone,

${ }^{354}$ Toronto Daily Star, 22 September 1941. In a search of the Winnipeg Free Press and Star Phoenix, using Carleton University Library National Newspaper Index, Smith, Johnson, and McCloud do not appear.

${ }^{355}$ The other article in her scrapbook was from the Ottawa Joumal, which ran a photo-article about Miller, on 1 October 1941, announcing his prisoner of war status. This article repeated that which had been printed in the Renfrew Mercury: "Sgt. Erle Sinclair Miller, 21, formerly of Renfrew, is son of Mr. and Mrs. Donald Miller, Castleford, Ont. He went overseas in August, 1940, and transferred to R.A.F in February. His parents were notified of his present whereabouts after had been reported as missing September 7." Ottawa Journal, 1 October 1941. ${ }^{356}$ Globe and Mail, 30 September 1941.

${ }^{357}$ The Miller Collection does not contain any letters written by these women, and it is not known whether Gladys wrote to any of them.

${ }^{358}$ The Miller Collection letters from this period are primarily from Miller, which were all addressed to "mother". Additionally, 56 letters are addressed to "Gladys" and 22 to "Mrs. Miller", a name choice which suggests that Gladys received correspondence primarily from those she knew well, or at least felt comfortable enough with her to use her first name. 
but she, in turn, became the conduit of news of her son's status to extended family, friends, and the surrounding community. ${ }^{359}$

The Millers waited until this information was confirmed by the Air Ministry and then relayed the news to the larger community via the Renfrew Mercury on 2 October $1941 .^{360}$ In the local news section, a short article placed the local community of the concerned at ease: "All were pleased to hear that Mr. and Mrs. Donald Miller had received word that their son Erle was alive and in a German prison. Not a very desirable position, but life is sweet and all hope he may be treated kindly if it is possible to hope for such things in Germany."361 The item also revealed something of the relief which greeted the news of Miller's status:

There is much joy at the Donald Miller home in Castleford, mixed with sympathy for their son Erle's disappointment for being put out of action. During the week-end, according to despatches[sic], German sources reported Sergt.-Pilot Erle Miller is a prisoner of war in Germany. "From the time he was reported missing I had a feeling he was all right," Mrs. Miller told the Mercury. "At times my hopes dropped pretty low, but I still had what you might call a hunch he was

\footnotetext{
${ }^{359}$ In her work on British prisoner of war families, Barbara Hately-Broad discusses the confusion surrounding obtaining reliable information regarding missing servicemen. While Britain had established a schema for dealing with POW matters that actively involved government departments, "not all POW matters fall under the jurisdiction of the Directorate of Prisoners of War (...). As a result, relatives were faced with a bewildering array of sources when trying to obtain information about missing servicemen." The Miller Collection shows that many concerned parties chose to write to Gladys directly rather than deal with the associated Canadian and international institutions, organizations, and agencies. Barbara Hately-Broad, "Nobody Would Tell You Anything": The War and Foreign Offices and British Prisoner of War Families during World War II," Joumal of Family History 27 (2002): 461. ${ }^{360}$ Miller's status was confirmed in a letter sent from the Wing Commander Beauchamp, which read, "I have to refer to my letter dated the 10th September, 1941, and to inform you with much pleasure that I have received information to the effect that your Son[sic] is a Prisoner of War." Wing Commander Beauchamp, Lincoln, UK to Donald Miller, Castleford, Ontario, 26 September 1941.

${ }^{361}$ Renfrew Mercury, 2 October 1941. The last sentence of this article, suggesting that a basic level of humanitarian care might not exist in Germany, was in keeping with the paper's depiction of the country and its leader, Adolf Hitler. This was also hinted at in a letter that Gladys received from Jena Marty, but even though she viewed the Germans in the same light as the Renfrew Mercury, she believed that the POW experience would not be impacted by this: "He may not be quite as comfortable in a prisoner camp but he isn't flying around being shot at either, which is one consolation. Our side has so many German prisoners that they nearly have to treat our boys half decent or they would get it back on them. But wouldn't it be grand if it was all over. If it lasts much longer, my boy will be in it too." Jena Marty, Donald, Alberta to Gladys Miller, Castleford, Ontario, 27 November 1941. While the Miller Collection does not offer other references to Mrs. Marty, her appreciation of how Canadian prisoners of war would be treated in Germany was in keeping with the comments contained in the letter Gladys received from Catherine McCallum (previously cited) in September 1941.
} 
alive. The news that he is a prisoner is good to us, but I know it will be disappointing to him because now he's out of it." 362

This article not only informed the Ottawa Valley of Miller's newly confirmed status as a Prisoner of War, but it also offered Gladys's interpretation of what this change meant for her family's war experience. This article suggests that Gladys was relieved by the news that her son was a prisoner of war, as she now considered him to be out of harm's way. Of particular note, however, are the last few words of this article; Gladys clearly believes that her son's status as a prisoner meant that he was no longer in the war. ${ }^{363}$

Miller's change in status from 'missing-in-action' to prisoner of war happened relatively quickly. The Miller Collection contains only four letters which concern his capture; the first was sent from Mrs. LeBarron:

I just had to write you a note. I had a letter from your mother, and she told me about your son Erle. I know how you would feel waiting to hear. But I am so thankful that he is alive and well. And I do hope that this awfull[sic] war will soon end. And Gladys I would like to get Erle's address that we could write him and would you tell me how to send boxes and where too and what can be sent. And do you know how many they can get a month? The girls and I would like to send him some boxes if you will let me know how to send them and where I think it will help if he gets boxes and letters all the time and if you will tell me what time of the month or weeks you send them we could send between times that is if they will let them have them. ${ }^{364}$

In this letter was the general understanding by members of the home front community that in order to assist Canadians behind barbed wire, through the shipment of food, materials, and letters, one had to initiate the process by contacting the captive's mother, as she was in the best position to pass on valuable information, such as his address and the names of various available resources. This networking is reflected in a letter written to Gladys from Flying Officer Wichens:

\footnotetext{
${ }^{362}$ Renfrew Mercury, 2 October 1941.

${ }^{363}$ Renfrew Mercury, 25 September 1941.

364 Jennie LeBarron, Deloraine, Manitoba, to Gladys Miller, Castleford, Ontario, 22 November 1941.
} 
I received a letter from Mrs. Earl Findlay of Bristol, Quebec. Her son Bruce, who was with me, is now a P.O.W. She has not received any mail from him yet. You can picture for yourself how she was feeling. I wrote to her to-night and suggested that she drop you a line. I thought you would be the right person to tell her what to exspect[sic] in the way of mail or parcels. I explained to her about how long Erle had already been there and that I hoped he and her son would soon be coming back home with the rest of us. ${ }^{365}$

While mothers of airmen transferred knowledge of timelines and expectations to other mothers, they also shared in their concern and grief. It was through these exchanges of information and comfort, that Gladys was supported by this community of women in similar situations to her own. This correspondence is an example of the community's ability to mobilize its network to act in defence of loved ones. In so doing, these exchanges undoubtedly enhanced the bond between its members, Gladys amongst them. She received the following letter, in September 1941, which offers a brief glimpse into the types of correspondence that mothers of missing airmen, who did not know one another, might send:

I'm taking the liberty of writing to you to ask you if you would be good enough to give a little information about the reports you have received with regard to your son Sergeant Earl Sinclair Miller.

My sister here had a cable from the War Office in London on the 14th of Aug. reporting that her son Sergeant Harry Dickson was missing after air operations carried on the night of Aug. 12th. He was one of the bombing crew. She has since had no further word except an unofficial communication from a Rotarian in London who says he has no definite word of Harry but information has been received that his first and second pilot are prisoners of war. My sister is becoming so frantic because she hears nothing further. I thought perhaps if your first word was received prior to her message and you have just now received the "prisoner" message, it might help to reassure her that there is still hope of Harry being alive. Would you be good enough to drop me a line and tell me just when your son was first reported

${ }^{365}$ F/O Wichens to Gladys Miller, 7 April 1944. The Miller Collection does not provide any further correspondence regarding Wichens. He is believed, however, to have survived the war as his name does not appear at the Commonwealth War Graves Commission website. 
missing, where he was flying from, and what day you received official word that he was a prisoner. It will help her in any case. ${ }^{366}$

These types of letters in the Miller Collection suggest that the dissemination of knowledge of prisoner-related information and existing aid organizations were primarily facilitated through female networks on the home front. This was an especially large community, as, at the peak of female employment in the fall of 1944 , more than $1,000,000$ women were working full-time in Canada's paid labour force. ${ }^{367}$ In these supportive, informal relationships, Gladys had not only been comforted by the kind words and actions of others, but had also offered reassurance and assistance to those in need.

While the Miller Collection does not contain any documentation that suggests that Mrs. Miller was involved in locally organized endeavors to support the Canadian war effort, her involvement in such tasks is highly likely given her deeply rooted interest in the cause. Annoncements, such as the following taken from 11 December 1941 Renfrew Mercury, informed its readership of the efforts made by female members of the community to contribute to the Canadian cause: "The ladies of Castleford met at the home of Mrs. Towie on Thursday of last week and quilted two quilts to send to the bombed-out people of England." 368 The narrative of women and the war, as expressed in both the Renfrew Mercury, and the correspondence Gladys received, presented a gendered and domestic understanding of how women could participate. By being 'brave' in the face of familial uncertainties and providing goods for men in service or in

\footnotetext{
${ }^{366}$ W. Houston, London, Ontario to Gladys Miller, Castleford, Ontario, 23 September 1941.The Miller Collection does not provide Gladys's possible reply, nor any further communication from this sender.

${ }^{367}$ Ruth Pierson, Canadian Women and the Second World War (Ottawa: Canadian Historical Association Historical Booklet, 1983), 9.

${ }^{368}$ Renfrew Mercury, 11 December 1941. Typically, these efforts were organized into hundreds of local societies and clubs, which were orchestrated by the local Women's Voluntary Services Centres under the direction of Ottawa's WVS. In her work on women's voluntary efforts, Pierson states that, "within these individual clubs, women sewed, knitted and quilted, packed parcels, and put together "ditty bags" containing small necessities for the servicemen and women overseas. They also made jam, collected clothing bundles, and raised milk money for Britain." Pierson, Canadian Women, 1983, 17. The Miller Collection does not indicate that Gladys was part of any such large scale activities.
} 
prisoner of war camps overseas, Gladys's wartime role was not only informed through her relationship to her son, but also through the Renfrew Mercury and the various pieces of correspondence she received. The expectations placed on Gladys, as a mother on the Canadian home front, were not solely directed towards providing for her so, but also as part of home front effort to provide for Canadians, both in service and in prison camps, overseas.

The Miller Collection highlights the various communities of support that were available to Gladys through concerned individuals, but it also indicates that there was a community of organizations which she also had at her disposal. The Miller Collection suggests that Gladys interacted with businesses and formal organizations that were central to the support received by prisoners of war overseas, as the Miller Collection contains 20 letters which span Miller's four year behind barbed wire. ${ }^{369}$ Three such institutions appearing in the collection are the Canadian Red Cross Society (CRCS), the War Prisoners' Aid of the World's Alliance of YMCAs, and the Canadian Prisoners of War Relatives Association. ${ }^{370}$ During the war, the CRCS was split into provincial divisions and had hundreds of branches across the country staffed with volunteers who engaged in fundraising activities in support of Canadian troops, POWs and other worthy

\footnotetext{
${ }^{369}$ These senders include James Hope and Sons Limited (Ottawa, Ontario), J. D. McAllister General Merchant (Mundare, Alberta), the Prisoners of War Relatives Association of Ontario, Federated Hardware Mutuals (Toronto, Ontario), The Robert Simpson Company Limited (Toronto, Ontario), and the Post Office Department (Ottawa, Ontario).

${ }^{370}$ For an in-depth discussion of these organizations see Jonathan Vance, "Canadian Relief Agencies and Prisoners of War, 1939-1945," Journal of Canadian Studies 31 (1996): 133-147. While the Miller family would not have been aware of the inner workings of these three groups, a document exists in the MC that highlights the expansion of the Red Cross. An "Information and News Sheet" published by British Prisoner of War Books and Games Fund and Forget-Me-Not League and sent to Mrs. Miller, read, "We announce at interesting development. When we started our quarterly Bulletin, there was no other Prisoner of War magazine published in England, and it met a great and urgent need. Since then, the Red Cross has decided to issue a journal on similar lines, and we feel that no useful purpose would be served by duplication at a time when paper economy is so vital. We, therefore, propose to issue from time to time as necessity arises full authoritative accounts of conditions in the camps, taken from the many thousands of letters we receive from our men who are Prisoners of War and these will be made available to next-ofkin." British Prisoner of War Books and Games Fund and Forget-Me-Not League, October 1942 Quarterly, The Bulletin.
} 
causes. ${ }^{371}$ The Red Cross was actively involved in the Renfrew community and facilitated various fundraising campaigns, the first of which was promoted in the 2 November 1939. Such local efforts were part of national drives which was carried out at all levels by Canadian volunteers, whose efforts amounted to an estimated $97 \%$ of the total work. ${ }^{372}$ Much of this work was organized and done by women, and tens of thousands participated each year in arranging and carrying out various fundraising plans in cities, towns and villages across the country. ${ }^{373}$ Women volunteers were usually assigned the duty of conducting the house-to-house canvassing and, more often than not, had great success in carrying out these tasks. ${ }^{374}$ Though voluntarism conformed to gender-based stereotypes associated with women and labour, as it was also an unpaid service, such activities generated potential pride and confidence for women on the home front in support of the drive to victory; these were important factors in the formulation of public opinion and the creation of civilian morale.

Although the Miller Collection indicates that Gladys provided donations for such campaigns, her primary concern remained with her son and his comfort while behind barbed wire. ${ }^{375}$ Just as she had done during his year of service, Gladys continued to send letters and

${ }^{371}$ Vance, "Canadian Relief Agencies," 134. A branch of the International Red Cross based in neutral Switzerland, the CRCS had also been recognized by the Department of External Affairs in late April 1940, as Canada's official voluntary aid society under Article 10 of the 1929 Geneva Convention relative to the Treatment of Prisoners of War. 372 Vance, "Canadian Relief Agencies," 136.

${ }^{373}$ The Canada Red Cross became embedded in Canadian society through its extensive war work, raising $\$ 80$ million in money and materials for the comfort and relief of the sick and wounded by the war's end. By this point, one-quarter of the Canadian population were active Red Cross Members. "Canadian Red Cross - Centennial Celebration," Canadian Red Cross, accessed 4 June 2012, www.redcross.ca/centennialtimeline/1940.html.

${ }^{374}$ Many women served in positions of authority, establishing and organizing the national objectives of the Red Cross. In addition to being involved in campaigning, women also volunteered their time and services to work in one of the six POW parcel packing plants across the country. They were also involved overseas, in the Canadian Red Cross Corps, which eventually numbered 15,000 women. "Responding to the Call of Duty during WWII," Canadian Red Cross, accessed 5 June 2012, www.redcross.ca/print.asp?id=013222.

${ }^{375}$ The Miller Collection contains one letter sent from the Salvation Army's Canadian War Services Women's Auxiliary which thanks Gladys for her financial donation: "As the blessed festival of Christmas dawns again upon a worn-torn world, our thoughts turn to those 40,000 Canadian mothers, sisters and wives across Canada, who have laboured so arduously throughout the year to help keep the stream of comforts going forward to our distressed friends in Britain and also for the men of the three services." This letter indicates that the Millers contributed to the 
parcels to her son. She had been informed by the Post Office Department, however, that POWs held in Germany " are permitted six or seven letters or cards per month, depending on the regulations in the camps in which they are interned." 376 The contents of Miller's letters were filled with requests for goods to be shipped to him from the home front, as they had been to some degree during his service, but these requests now assumed a very much more urgent character. In addition to parcels that were sent by the Miller family, the Red Cross actively sought to make available one food parcel per prisoner of war per week, from January 1941 until the end of the of the war. In all, the Red Cross packed and shipped nearly sixteen and a half million food parcels at a cost of $\$ 47,529,000$ for prisoners of war in Europe and the Far East. ${ }^{377}$

Cigarettes were highly sought after by Miller, although they were not included in Canadian Red Cross parcels. ${ }^{378}$ In order to facilitate the delivery of such a coveted commodity (cigarettes) to their son, the Millers received direction from the Post Office Department as to which organizations were permitted to forward cigarettes or tobacco directly to prisoners of war. While the Post Office provided a short list of companies that could ship parcels to prisoners of war overseas, the Canadian Prisoners of War Relatives Association provided the family with a

Canadian war effort in addition to the needs of their captive son. Jane Peacock, Toronto, Ontario, to Gladys Miller, Castleford Ontario, 8 December 1942.

${ }^{376}$ Post Office Department, Ottawa, Ontario, to Gladys Miller, Castleford, Ontario, 18 November 1941. While Gladys continued to write avidly to her son, she now knew not to expect the same flow of letters in return.

377 This cost was defrayed jointly by the British, Australian, and Canadian Red Cross Societies. For the CRCS it was its costliest wartime service, with roughly half of each yearly budget being spent on the production and delivery of parcels to POWs. Frederick Tisdall, "Final Report on the Canadian Red Cross Food Parcels for Prisoners-of-War," Canadian Medical Association Journal (March 1949): 279.

${ }^{378}$ Canadian parcels traditionally contained the following items: whole milk powder; butter; cheese; corned beef; pork luncheon meat; salmon; sardines; dried apples; dried prunes; sugar; jam; pilot biscuits; eating chocolate; salt and pepper; tea; and soap. At times, however, raisins were substituted for prunes, honey for jam, coffee for tea, and the addition of onion powder, mustard and other condiments. In the Final Report on the Canadian Red Cross Food Parcels for Prisoners-of-War, a section on the prisoner parcel preference, reads "In reply to the question "Which parcel you prefer?"(...) 82\% of the R.C.A.F., 82\% of the Canadian Army and 71\% of the British Army gave first preference to the Canadian parcel. This expressed preference was supported in the majority of cases by such statements as "greater bulk", "lasted longer", "more food", etc., and by reference to specific items which were specially appreciated or preferred." Frederick Tisdall, "Final Report", 280-282. Even with the exclusions of cigarettes, Canadian standard food parcels were highly sought after. 
more complete list. ${ }^{379}$ These lists were important tools as not all stores had permits which enabled them to provide materials to prisoners of war. With the requests for books and course materials from her son, Gladys quickly established links with local companies. A month after Miller's POW status had been confirmed, Gladys heard from the Robert Simpson Company Limited, a Canadian department store chain.

It gives us pleasure to respond to your recent enquiry by advising that we hold permits for sending books, playing cards and games, also cigarettes and tobacco to prisoner of war, postage free. Parcels are limited to eleven (11) pounds each and the following form of address is demanded: - Regimental number, Rank, Name, Canadian (or British), Prisoner of War, Camp or Number, Name of Country, Base Post Office. Unfortunately we do have not a list of book titles but can supply Penguin series at 20cents each and others at 59cents, 98cents and $\$ 1.39$ each. ${ }^{380}$

The exclusion of cigarettes from Canadian personal parcels became a contentious issue, largely because no such ban existed in the United States. As a result, Canadian POWs began to instruct relatives to send their quarterly parcels from the United States rather than from their home country. In April 1942 Miller wrote that, "A lot of the Canadians are still receiving food parcels from America. If we have any American friends you might send thru them. ${ }^{381}$ A few months later, Miller provided his mother with the name of a fellow captive's mother who lived

\footnotetext{
${ }^{379}$ Post Office Department, Ottawa, Ontario, to Mrs. Donald Miller, Castleford, Ontario, 4 November 1941. The Post Office listed the following four companies: the Imperial Tobacco Company (Montreal); W.C.Macdonald Incorporated (Montreal); Rock City Tobacco Company (Quebec) and Tucketts Limited (Hamilton). In addition to the above mentioned companies, the Canadian Prisoners of War Relatives Association list of companies included: $B$. Houde \& Grothe, Ltd., Montreal, P.Q., Benson and Hedges (Canada) Ltd., Montreal, P.Q., H. Simon and Sons Ltd., Montreal, P.Q., Landau \& Cormack Ltd., Montreal, P.Q., Cie de Tabac Terrebone, Montreal, P.Q., and the Royal Canadian Tobacco Company, Ltd., Toronto, Ont.

${ }^{380}$ Kathleen Dunne, Toronto, Ontario, to Gladys Miller, to Castleford, Ontario, 22 October 1941. Gladys contacted this company prior to having received any contact from her son, which demonstrated her intuitive understanding of what material goods would help him endure his captivity. While the company did not publish any advertisements in the Renfrew Mercury, the Miller Collection contains a letter from the Ontario Division of the Red Cross Society which listed stores and companies (Robert Simpson Company being one of them) that were permitted to forward goods to prisoners of war overseas. The Robert Simpson Company was bought by the Hudson's Bay Company in 1978 , and was closed in the 1990 s.

${ }^{381}$ Erle Miller to Gladys Miller, 26 April 1942.
} 
in the United States and was willing to send parcels to him. ${ }^{382}$ Through such correspondence home, Miller was able to exercise a measure of personal agency from afar and improve his situation by making his mother aware of existing systems of provision for POWs. Gladys contacted Mrs. Peterson and received the following letter in return:

I have been a little slow answering your letter but I know you would rather hear that we had mailed the package to Erle than to hear we were getting it ready. I just got it mailed this past Mon. the 5th. Takes quite awhile to get a license. Have to write to Washington D.C. and get a license for each package. Don't expect he will get it before Christmas. One of the women I work with has applied for a license to send him a package too. Expect she will get it next week. I will apply for another after she gets hers mailed. I'll send you a list of what I sent. When you write again suggest some of the things you think he would like most. ${ }^{383}$

By the end of the year, so many relatives and friends were shipping parcels through the United States that the Canadian Red Cross complained to the Special Section of External Affairs. ${ }^{384}$ While External Affairs attempted to put constraints on the United States Postal Service, the end result was to bring Canadian rules in line to permit the inclusion of food items such as dried fruits (in addition to the dried apples and prunes already provided in parcels), nuts, macaroni and soups in personal parcels. While the British government pressured against this change, due to the implications that this might have had on their own food parcel standards, the

\footnotetext{
${ }^{382}$ Erle Miller to Gladys Miller, 20 July 1942. The related comment in this letter read, "Write to Pete's mother, Mrs. M. Peterson 1518-19 Ave. Seattle, Washington." Miller mentioned Mrs. Peterson, Pete's mother, seven other times during his correspondence home in 1942.

${ }^{383}$ Mrs. Peterson, Washington, D.C., to Gladys Miller, Castleford, Ontario, 9 October 1942. The last sentence of this letter suggests that Mrs. Peterson understood this to be a relationship that would continue. The Miller Collection does not contain any further correspondence from Mrs. Peterson, which suggests that this had been a relationship of purpose or function, and not friendship.

384 This department, under Alfred Rive, facilitated dialogue between Allied and neutral governments on all matters concerning POWs, from policy to the activities of the International Committee of the Red Cross. In this article on Canadian relief agencies for prisoners of war during the Second World War, Jonathan Vance asserts that, while the goal to provide for POWs was shared by all agencies and organizations, the main three, "the Canadian Red Cross Society, the War Prisoners' Aid of the World's Alliance of the YMCAS, and the Canadian POW Relative Association, (...) created a host of problems for the government." Due to awkward and inefficient leadership on the part of the Canadian Government, rivalries and ill-will developed between these three main relief organizations. Jonathan Vance, “Canadian Relief Agencies", 140 -142.
} 
Special Section of External Affairs published a list on 9 November 1942 which revised the list of food items allowed in the quarterly parcels. ${ }^{385}$ As a result of this change in policy, Gladys was able to provide Miller with the items he sought through Canada, rather than through the United States.

The Miller Collection's letters that speak to Gladys' effort on the Canadian home front reflect two main communities of support, those who offered comfort to the Miller family, and aid organizations that Gladys contacted in order to provide for her son's mental and physical health. The former group, which consisted of family and friends, was overwhelming female and offers insight into the gendered understanding of the duty and compassion shared between the sisterhood of women whose loved ones had been taken prisoner of war. Very little has been written about the nature and function of these private and personal relationships and the Miller Collection, in its depth and fullness, highlights the centrality that these networks played in caring for the prisoner overseas. While organizations, such as the YMCA and CRCS, were a part of Gladys' roster of support for her son, she found comfort in the 117 letters from those who knew her family or were able to relate to her situation. While Gladys provided her son during his four year as a prisoner of war, it was this community of the concerned that served as her greatest comfort during what was surely a mother's darkest hour.

\footnotetext{
${ }^{385}$ The British Government presented a number of arguments in support of its case, such as the fact that the Germans had already reduced food rations twice based on the observation that too much food was being wasted on account of the number of parcels reaching POWs. In his work on the subject, Vance argues that "British officials also wondered if relatives would be satisfied with quarterly parcels, and thought that opening the door to nominative food parcels would merely bring demands that such parcels be allowed more frequently, to the detriment of the standard food parcel campaign." Jonathan Vance, "Canadian Relief Agencies”, 140.
} 


\section{Conclusion}

Upon returning to Canada after the Second World War, Miller moved back into his family's home in Castleford, Ontario. While a young and fit man during his passage across the dangerous waters of the Atlantic to Britain in the late summer of 1940 , his return voyage in June of 1945 was under very different circumstances. The trip home to Canada was a much safer one, as the war against Germany was over and the U-Boat threat gone. But Miller faced other threats: physically weakened after enduring nine months of severe malnutrition at his last permanent camp, Stalag XIB at Fallingbostel, his health was further undermined by the starvation rations that scarcely sustained him during his one month forced march from Fallingbostel to Molln in May 1945. A few months after his return to Canada, Miller was sent to Ottawa's Rockcliffe Station Hospital to have a tooth removed. His weakened immune system could barely withstand the operation; his family was informed after his surgery that, "Your P.O [Post Operative] MILLER is placed on seriously ILL list at Rockcliffe Station Hospital at 4pm 24 AUGUST with infection of Pharyngo Maxillary Space following tooth extraction stop will be notified of any change in his condition." ${ }^{386}$ Although Miller had survived the war, when so many others from the community had not, his physical health had been temporarily ruined.

As an adult and father, Miller's four plus years of incarceration had a lasting impact on his appreciation for food, and he was notorious for reminding his family to: "Finish your plate...there are people starving...during the war the food on your plate would have fed many

\footnotetext{
386 RCAF Station Rockcliffe (no title or name given) to Donald Miller, Telegraph, 24 August 1945. An infection in this area would result in swelling and inflammation in the space between the throat and upper jawbone. "Pharnygo," Oxford English Dictionary, accessed 2 December 2012, http://www.oed.com.proxy.library.carleton.ca/view/Entry/142260?redirectedFrom=Pharyngo\#eid.
} 
starving mouths." 387 While Miller was able to successfully reintegrate himself into his home front community and regain his physical strength and well-being, certain routine activities where challenging for the ex-POW. ${ }^{388}$ This was most apparent in his discomfort in cramped spaces, as the confines of camp living had left an emotional scar on Miller's sense of space. In recounting her father's unease towards such environments, Julie Miller, Miller's second eldest child commented:

Throughout my entire elementary and high school education I was afforded music lessons, specifically violin lessons. I remember annual Kiwanis Music Festivals with mixed emotions. In the early years, on more than one occasion, I remember being included in the Stars of the Festival and my mother insisting my father accompany us to the evening concert. My father would position himself usually in the back row closest to the door. My mother always claimed it was nerves related to the war. I can only assume this to be accurate as with most veterans, both then and now, the experience takes its toll psychologically. ${ }^{389}$

It would appear that although Miller attempted to leave the war years behind him, his mind was unable to completely forget or ignore them.

During his two month stay in Castleford, before he was sent to Ottawa, Miller had begun a relationship with a friend of his younger sister, Cleta Barr. ${ }^{390}$ Cleta saw Miller almost immediately after he had returned home:

\footnotetext{
387 Julie Miller, Ottawa, Ontario, to Emily Gann, Ottawa, Ontario, 3 July 2012.

${ }^{388}$ Upon his return to Canada, Miller did not apply for benefits from the Veteran's Charter. While the Charter had grants in place for small businesses, such as the Veteran's Business and Professional Loans Act (1946), Miller pursued this venture independently. For more information on the development and implementation of the Veteran's Charter, refer to Peter Neary and Jack Granatstein, The Veterans Charter and Post-World War II Canada (Montreal: McGill-Queen's University Press, 1997). This study also offers an extensive review of the existing literature on the topic of Canadian Second World War Veterans. Within this body of scholarship, Neary and Granatstein highlight the following three works as seminal studies on veterans and reminiscences of the war: Barry Broadfoot, Six War Years: Memories of Canadians at Home and Broad (Toronto: Doubleday Canada, 1974), Barry Broadfoot, The Veterans' Years: Coming Home from the War (Vancouver/Toronto: Douglas \& McIntyre, 1985), and Ted and Alex Barris, Days of Victory: Canadians Remember, 1939-1945 (Toronto: Macmillan Company Canada, 1995). More recently, Serge Durflinger's Veterans with a Vision: Canada's War Blinded in Peace and War (Vancouver: UBC Press, 2010) offers insight into the veterans experience.

${ }^{389}$ Julie Miller to Emily Gann, 3 July 2012.

${ }^{390}$ Cleta had been visiting with the family when Miller left for war in 1940 and, in describing that evening, she recalled that "never in my imagination did I dream I would eventually marry this young nineteen year old man." Her
} 
The second evening after his [Miller's] arrival in Renfrew, his home town, his sister and uncle took him to the Renfrew Golf Club. There, he met my brother Mal. A telephone call was made to me and I invited them up to the farm. I was a registered nurse then but I was home helping my brother on the farm while my parents had their first real holiday. After two years of dating Erle and getting to know each other we married May $1^{\text {st }}, 1947 .^{391}$

Four years later, in August 1951, Cleta and Miller had their first child, Ann Christine Miller. Over the course of the next nine years, they would have three more daughters: Julie Elaine Miller (1952), Lori Elizabeth Miller (1956) and Robin Erliss Miller (1960). The family of six lived in Lyn, Ontario, on a small farm where Cleta remained at home with the girls and Miller ran a small business called Miller's Red \& White General Store. ${ }^{392}$ Miller had found it difficult to find fulfilling employment immediately after the war, which resulted in him changing jobs rather frequently. In recalling her husband's work history, Cleta wrote, "He tried three different jobs. In each case, he realized very early on that he was not satisfied with the job and would call to say he quit. The answer was always the same, "No, you didn't quit - we fired you." It was then he realized he would have to work for himself." ${ }^{393}$ His second eldest daughter, Julie Miller, recalled that her father was "a wonderful provider":

I can remember Dad's very obvious pleasure in bringing home several huge boxes of food, the weekly food order, at the end of Saturday's work day. I can only surmise that when you have experienced starvation for three plus years during your early twenties, food takes on a different status. The Dad I knew in my youth was almost obsessed with having more on the table than less and became quite anxious at the prospect of there not being enough food. ${ }^{394}$

letter also contained the following description of his departure: "Erle was scheduled to leave home for overseas May.... (??? not sure of the exact date) and Marg wanted me to come home with her the night of his departure as she didn't want to be alone with her parents after Erle left on the train. I do remember Mr. Miller standing outside the door like a lamp post for some time. I can only imagine his thoughts." Cleta Barr, Brockville, Ontario, to Emily Gann, Ottawa, Ontario, 3 July 2012.

${ }^{391}$ Cleta Barr to Emily Gann, 3 July 2012.

${ }^{392}$ Ibid.

${ }^{393}$ Cleta Barr to Emily Gann, 3 July 2012.

${ }^{394}$ Julie Miller to Emily Gann, 3 July 2012. 
The contents of the Miller Collection allow for an appreciation of Miller and his mother's experiences during the war years, but this rich and lengthy letter set ends in 1945. As such, this collection does not allow for an understanding of his postwar career and I have turned, instead, to his surviving family members, Cleta Miller, Ann Wilson, Julie Miller, Lori Wells, Robin Lean, and Alex Wilson, and asked them to reflect on Miller's as a veteran, and provide insight into how his wartime experiences impacted him throughout the second half of the twentieth century. While all of Miller's family knew of his active military service in the RCAF, none of the letters made any reference to his RCAF experience, and focused instead on Miller's time as a prisoner. It is apparent in these letters that, as his eldest daughter Ann stated, "In a nut shell $[\ldots]$ he didn't 'play that card'. Being the eldest I would probably have more memories than my three sisters, but frankly there was very little mention of this period of his life in our early lives." ${ }^{395}$ The sentiment is expressed differently in all four letters from his children, but Julie's letter offers a deeper, more personal understanding of her father's reticence regarding his wartime experiences:

I am not sure if this is the norm but my Dad was not very forthcoming about his experiences before, during and after the war. This could have been a coping strategy which would be reasonable considering his three years plus in a POW camp coupled with my lack of interest and/or ignorance as a young child. ${ }^{396}$

The letters from Julie's sisters and mother also express a sense of personal responsibility for Miller's very limited discussion of his war time experiences. This is mostly aptly stated by Cleta who commented; "I'm sure I could have been more inquisitive regarding his POW time but I felt the war was over, so why rehash it." ${ }^{397}$ In his work on Allied POWs during the Second World War, Adrian Gilbert observes that prisoners of war had mixed emotions when it came to how

\footnotetext{
${ }^{395}$ Ann Wilson, St. Catharines, Ontario, to Emily Gann, Ottawa, Ontario. 3 July 2012.

396 Julie Miller to Emily Gann, 3 July 2012.

${ }^{397}$ Cleta Miller to Emily Gann, 3 July 2012.
} 
they remembered their time behind barbed wire. But while "the war and imprisonment were events of central importance that continued to have a profound influence on their post-war lives", in Miller's case, it appears clear that, in spite of this deep seated and long lasting impact, he was not interested in reliving his past and his family did not press him to do so. ${ }^{398}$ Miller's eldest grandchild, Alex, can recall having several chats as a child about the war and POW life with his grandfather, but Erle Miller did not share these memories outside of the family. Robert Kirby, the author of Avro Manchester: The Legend Behind the Lancaster, a study which provides a detailed account of the L7380 Manchester's last sortie and crash landing in the early morning of 8 September 1941, attempted to contact Miller 50 years after the war. As one of two men from the crew alive in 1995, Kirby's research aspirations were met with apathy as Miller "was tracked down but had no interest in reunions or the history."399

As a piece of family history, the Miller Collection has remained relatively untouched by the extended Miller family. Indeed, Julie recently revealed that: "All my growing up years I never knew my Gramma Gladys had kept all the correspondence from my Dad during the war. ${ }^{400}$ After Gladys sold the family home, the collection moved to Lyn, Ontario, in the late 1960s and, in recalling the collection's arrival at her childhood home, Ann wrote:

I remember looking at them when my Aunt (Dad's sister, Margaret) dropped them off at our house. Dad showed interest and spent some time flipping through them but they were soon bundled up and sent to the attic. When the family home was sold, I took them along with his medals and uniform. I don't think he gave them much thought. In fact, his medals were in their original envelopes. ${ }^{401}$

\footnotetext{
${ }^{398}$ Adrian Gilbert, POW: Allied Prisoners in Europe, 1939-1945 (Great Britain: John Murray, 2006), 322.

${ }^{399}$ The other surviving crew member was Sergeant Sam Powell, the Second Pilot. He "expressed a willingness to contribute his memories of his time in 207 Squadron, including the loss of $\mathbf{L} 7380$ but, sadly, died suddenly before matters could be progressed." "207 Squadron - Manchesters," Robert Kirby, accessed 4 December 2012, http://www.207squadron.rafinfo.org.uk/manchesters/manchesters_L7380ameland.html.

400 Julie Miller to Emily Gann, 3 July 2012.

${ }^{401}$ Ann Wilson to Emily Gann, 3 July 2012.
} 
The Miller Collection offers an account of a young man's Second World War experience through his letters and journals. It highlights the special bond between mother and son and showcases the written and material support that a family provided for their loved one overseas. Extending beyond this close familial bond, the collection allows for an analysis of the various communities of war that RCAF airmen, Canadian prisoners of war, and civilians formed . In Chapter One, "Sgt. Miller," these connections informed Miller's nationalism and allowed him to feel a strong bond to his home country. This is a theme that is developed throughout the letters Miller sent to his mother during his active service, such as the note he sent to her in March 1941: "You can't beat the Canadians I don't think. I never knew I was a Canadian so much as since I've come over here." ${ }^{\text {402 }}$ In Chapter Two, "Prisoner of War", Miller's ability to survive his incarceration was dependent upon his own personal resolve and his local Ottawa Valley community that supplied him with letters and parcels. The last two chapters collectively illustrate the needs of a prisoner of war and the channels through which these needs were met by his home front support system. This effort, spearheaded by Gladys Miller, is the focus of Chapter Three, "Mother on the Home Front", which focuses on the various groups of people, businesses, agencies and organizations that a mother could call upon in order to provide for her son behind barbed wire.

These last two chapters also present new areas of research within the growing historiographies of prisoners of war life and the Canadian home front during the Second World War. "Prisoner of War" is in keeping with recent scholarship, such as the work done by S.P. Mackenzie (2006) and Adrian Gilbert (2006), both of whom attempt to deconstruct the 'myth' of

${ }^{402}$ Erle Miller to Gladys Miller, 8 March 1941. 
POW life and draw out the nuanced experiences behind barbed wire. ${ }^{403}$ The last chapter of this thesis breaks new ground on the topic of Canadian women and war. The published work in this area offers a discussion of women and active service, and voluntary organizations, but has yet to depart beyond the study of such formalized institutions. In this way, the Miller Collection and "Mother on the Home Front" extends beyond the existing literature, and sheds new insight upon the nuanced networks from which women could obtain support for Canadian prisoners of war overseas.

Miller's return to Canada in June 1945, and marriage to Cleta two years later, was the start of a new chapter in Erle Miller's life. Within a decade the young couple became parents to four girls, and over the course of the next 40 years, Erle and Cleta Miller welcomed four son-inlaws and became Papa Dusty and Nana Cleta to 10 grandchildren. Miller passed in 1995 after an aggressive battle with cancer. My father, husband to Julie, gave the eulogy at Erle's funeral. I was a young child at the time and I do not remember that day or this eulogy, but I am certain that these words were moving for those that knew and loved my Papa Dusty:

Erle Sinclair Miller was born in Beaver Lake, Alberta on the fourteenth day of March, 1920 and died on the twentieth of April, 1995 in Brockville, Ontario. In between those dates lived a very fine person for whose memory we have gathered together today to honour and for whose friendship we collectively acknowledge

Hard times brought Donald, Gladys and young Erle Miller east to establish a new life in the Ottawa Valley. It was here that his sister Margaret was born. After attending Renfrew Public and Secondary Schools, Dusty then enrolled in and graduated from Renfrew Business College. Dusty was on his way to becoming a successful capitalist. However, world events overtook the plans of our budding entrepreneur. Responding to the call of his country, in the fall of 1939, Dusty at age 19, became one of the first in the Renfrew area to join the Royal Canadian Air Force. It was in 1941 on his $22^{\text {nd }}$ mission that his plane was shot down over the Dutch coast. Picked up by the Gestapo

${ }^{403}$ Adrian Gilbert, POW: Allied Prisoners in Europe, 1939-1945 (Great Britain: John Murray, 2006), and S.P. Mackenzie, The Colditz Myth: The Real Story of POW Life in Nazi German (Oxford: Oxford University Press, 2006). 
shortly after, he spent his $22^{\text {nd }}, 23^{\text {td }}, 24^{\text {th }}$ and $25^{\text {th }}$ birthdays as a prisoner of war, courtesy of the Third Reich.

During this time Dusty honed a number of skills, the least not being perseverance, that were going to serve him well in the future. He read books on language, on Mathematics and he read the Bible from front to back.

All of us can recall numerous times of sumptuous feasting at the Miller household. Being a generous provider for friends and family are attributed to those months and years of deprivation in the war camps.

With the war's end in May of 1945, at age 25 and after seven years of patriotic duty behind him, Dusty returned to Canada and to civilian life. It was over the next two years that Dusty re-established his acquaintance with a young woman by the name of Cleta Barr. That relationship was to be a major turning point in Dusty's life, for two years later they were married.

It was a newspaper ad in the Ottawa Citizen that was another turning point in Dusty's life. It told of a small store business for sale in the village of Lyn, just outside of Brockville. After checking it out with his mother, Dusty bought that business and moved to Lyn with his brand new wife in the spring of 1947. From hardware and groceries to appliances and electronics, from snowmobiles to furniture; through hard work, ten to twelve hour days, six days a week, through perseverance and with a fair amount of business acumen the business grew. And so did the Miller family - with Ann in 1951, Julie in 1952, Lori in 1956, and last but not least, Robin in 1960.

We all know that more than humans lived in the Miller household. Ever since the Renfrew Millers owned a cat named Jerry or the time that he tried to keep a stray dog, Dusty has loved animals: horses, dogs, cats, gerbels, turtles, goldfish, rabbits, budgies - they've all been part of the Miller Garden of Eden. And how many of you can recall hearing the story of Dusty chasing down a couple of the girls' renegade escaped horses through the fields of Lyn, in the middle of the night. Even in his last days, Dusty found comfort from the physical warmth afforded to him by David Wilson's new puppy Lizzie.

The Miller estate grew also - at first the family lived over the store and then Dusty, always the provider, purchased a cottage on Charleston Lake in 1956, and in 1960 a house on Perth Street in Lyn.

Perhaps for all of us it was the cottage that most typified our relationship with Dusty. It was indeed a people place, and Dusty defined cottage life hospitality personified: dancing, midnight feasts, dart competitions, and the occasional drink. And the pride that Dusty had when he spun the motorboat around the lake with all 4 daughters water-skiing behind at the same time. 
Over the span of 48 years, Dusty had nurtured a strong sense of community life in Lyn and later in Brockville, as a member of Lyn United Church, as Lyn postmaster from 1951 to 1985 , as realtor, and as member in good standing at the Brockville Golf and Country Club.

Over the years Dusty found time in his busy work schedule to travel with Cleta - to Europe, to South America, to the Caribbean, and during the years of retirement, to Arizona and Florida, and this last fall, a cruise along the Alaska panhandle.

He escorted each of his daughters up these aisles as they became married, and he reveled with his expanded family of 8 children. I speak on behalf of Rob, Greg, and Phil when I say that Dusty was more than a father-in-law; he was a friend and chum. And for us, also, he was the quintessential role model of a devoted husband and loving father.

And it is perhaps in this time of collective sorrow that we should recollect some moments of laughter:

- the time when Dusty was teaching Ann how to drive in the Volkswagen Beetle on the back roads to the cottage on Saturday evenings after working all day at the store. He'd get Ann behind the wheel, crack open a beer and open up the newspaper, lowering it occasionally to make sure that Ann was still on the road. She was only 13 at the time.

- And, the ingenious and elaborate systems concocted to win the 649 Lottery, one being a large hermetically sealed jar with meticulously painted and numbered marbles, chosen from which would be the weekly winning combination - or fairly close to it. Dusty enjoyed more dreaming about what he would do with the money than actually winning it.

Your love of family, your voracious reading habit, your exercise through golfing, curling, walking, your story-telling or prison camp days or hunting trips, your willingness to accept people the way they were - Dusty, these are all you.

It is because of all the memories, fun, enjoyment, love and give that your wife, Cleta, and your children and their families, your sister, Marg, and nephew, Don, and the wide circle of relatives and friends will miss you. Whether in a big or small way, you have influenced all of us.

I would like to conclude by reading part of a poem that one could hear Dusty say from time to time. It is entitled, 'The Vision of Sir Launfal', written by James Russell Lowell ${ }^{404}$ :

And what is so rare as a day in June?

${ }^{404}$ John Gann, Eulogy for Erle Sinclair Miller, Brockville, Ontario, April 1995. 
Then if ever, came perfect days;

Then Heaven tries earth if it be in time,

And over it softly her warm ear lays,

Whether we look, or whether we listen,

We hear life murmur, and see it glisten;

Every clod feels a stir of might,

An instinct within it that reaches and towers,

And, grasping blindly above it for light,

Climbs to a soul in grass and flowers;

The flush of life may well be seen

Thrilling back over hills and valleys;

The cowslip startles in meadows green, The buttercup catches the sun in its chalice, And there is never a leaf or a blade too mean

To be some happy creature's palace. ${ }^{405}$

${ }^{405}$ James Russell Lowell, The Vision of Sir Launfal (Boston: James R. Osgood and Company, 1871 ), 8. 


\section{Bibliography}

\section{Primary Sources}

\section{Main Collection}

Miller Collection, 1940 - 1945. Private collection kept by a member of the Miller family in Ottawa, Ontario.

297 Letters

2 Prisoner of War Journals

Royal Canadian Air Force Flying Log Book

\section{Manuscripts}

Collection of Letters Written to and from Flight-Lieutenant Duffy, 19 August 1940 - 28

December 1940, [20070044-022]. Flight Lieutenant Warren Alvin Duffy Collection.

Canadian War Museum, Ottawa, Ontario.

Correspondence to and from George Joseph Chequer, 10 February 1942 - 25 December 1944, [19910181-043]. Flight Lieutenant George Joseph Chequer Collection. Canadian War Museum, Ottawa, Ontario.

Dulag-Luft. Kriegsgefangenenkartei, 24 September 1944, [20080029-003]. Squadron Leader George Urquhart Hill Collection. Canadian War Museum, Ottawa, Ontario.

Flying Log Book, 20 April 1943 - 19 May 1943, [19770102-005]. Flight Lieutenant Miller Gore Brittain. Canadian War Museum, Ottawa, Ontario.

Letters, 19 November 1941 - 12 June 1945, [20030359-028]. Pilot Officer Guy Henri Rainville. Canadian War Museum, Ottawa, Ontario. Canadian War Museum, Ottawa, Ontario.

Letters from F/O Thomas R. Jones to his Parents, 1941 - 1943, [20010200-002]. Flight Lieutenant Thomas Reid Jones Collection.

Letters and Postcards to Mrs. George Hill, 1943-1945, [20080029-005]. Squadron Leader George Urquhart Hill. Canadian War Museum, Ottawa, Ontario.

Letters to Mrs. McKiel regarding George, 1944, [19980120-014]. Pilot Officer George Dicker McKiel Collection. Canadian War Museum, Ottawa, Ontario.

Military Correspondence, 1940, [19760138-007]. Pilot Officer Thomas Lloyd Bennett Collection. Canadian War Museum, Ottawa, Ontario.

Second World War Letter Collection of Norma Lee, 31 October 1941-30 August 1945, [20060058-001]. Norma Etta Lee Collection. Canadian War Museum, Ottawa, Ontario. 
Prisoner of War Identification Card, January 1944, [20030359-020]. Pilot Officer Guy Henri Rainville Collection. Canadian War Museum, Ottawa, Ontario.

Prisoner of War Letters, January 1944 - May 1945, [20030359-026]. Pilot Officer Guy Henri Rainville Collection. Canadian War Museum, Ottawa, Ontario.

Prisoner of War Notebook, March 1944 - September 1945, [20030359-029]. Pilot Officer Guy Henri Rainville Collection. Canadian War Museum, Ottawa, Ontario.

Wartime Correspondences of F/Lt. Leslie Neil McCaig, July 1941 - March 1949, [200601910044]. Flight Lieutenant Leslie Neil McCaig Collection. Canadian War Museum, Ottawa, Ontario.

Newspapers

Globe and Mail. Toronto, Ontario. 1941.

Ottawa Citizen. Ottawa, Ontario. 1941-1942.

Ottawa Journal. Ottawa, Ontario. 1941.

Renfrew Mercury. Renfrew, Ontario. 1939-1945.

Toronto Daily Star. Toronto, Ontario. 1941.

Winnipeg Free Press. Winnipeg, Manitoba. 1941-1943.

\section{Secondary Sources}

\section{Books}

Anderson, Benedict. Imagined Communities: Reflections on the Origin and Spread of Nationalism. London: Verso, 1991.

Barker, A.J. Behind Barbed Wire. London: B.T. Batsford, 1974.

Barris, Ted and Alex Barris. Days of Victory: Canadians Remember, 1939-1945. Toronto: Macmillan Company Canada, 1995.

Bashow, David. No Prouder Place: Canadians and the Bomber Command Experience, 1939 to 1945. St. Catharines: Vanwell Publishing Limited, 2005.

Benn, Tony. Years of Hope: Diaries, Letters and Papers, 1940-1962. London: Hutchinson, 1994. 
Berbrechter, Stefan and Michael Higgins, ed. Returning (to) Communities: Theory, Culture and Political Practice of the Communal. Amsterdam: Rodopi B.V., 2006.

Bickers, R.T. Home Run: Great RAF Escapes of the Second World War. London: Leo Cooper, 1992.

Blackshaw, Tony. Key Concepts in Community Studies. London: SAGE Publications Ltd., 2010.

Bliss, Michael. Right Honourable Men: The Descent of Canadian Politics from Macdonald to Chretien. Toronto: HarperCollins Publishers Ltd., 2004.

Bottomley, Nora. 424 Squadron History. Stittsville: Hangar Bookshelf, 1985.

Bower, Tom. Heroes of World War II. London: Boxtree, 1955.

Brickhill, Paul. The Great Escape. London: Faber \& Faber, 1953.

Broadfoot, Barry. Six War Years: Memories of Canadians at Home and Broad. Toronto: Doubleday Canada, 1974.

Broadfoot, Barry. The Veterans' Years: Coming Home from the War. Vancouver/Toronto: Douglas \& McIntyre, 1985.

Brookes, Andrew. Bomber Squadron at War. Londone: Ian Allan Ltd., 1983.

Brower, Charles ed. World War II in Europe: The Final Year. New York: St. Martin's Press, 1998.

Brown, Eric. Wings on My Sleeve. London: Weidenfeld \& Nicolson, 2006.

Brown, Kingsley. Bonds of Wire: A Memoir. Toronto: Collins, 1989.

Bruce, Jean. Back the Attack!: Canadian Women during the Second World War, at Home and Abroad. Michigan: University of Michigan, 1985.

Buckham, Robert. Forced March to Freedom. Stittsville: Canada's Wings, Inc., 1984.

Burgess, Alan. The Longest Tunnel: The True Story of World War II's Great Escape. London: Bloomsbury Publishing, 1990.

Calder, Angus. The People's War: Britain 1939-1945. London: PIMLICO, 1992.

Carrington, Charles. Soldier at Bomber Command. London: Leo Cooper: 1987.

Castle, John. The Password is Courage. London: Souvenir Press, 1985. 
Carter, William. Anglo-Canadian Wartime Relations, 1939-1945: RAF Bomber Command and No. 6 (Canadian) Group. New York: Garland Pub., 1991.

Clark, Albert. 33 Months as a POW in Stalag Luft III: A World War II Airman Tells His Story. Golden, Colorado: Fulcrum Publishing, 2004.

Cohen, Anthony. The Symbolic Construction of Community. London: Sage, 1985.

Cook, Tim. Clio's Warriors: Canadian Historians and the Writing of the World Wars.

Vancouver: UBC Press, 2006.

Cooke, Ronald and Roy Nesbit. Target: Hitler's Oil: Allied Attack on German Oil Supplies 1939-1945. London: William Kimber \& Co. Limited, 1985.

Costelle, John. Love, Sex and War: Changing Values 1939-1945. London: Williams Collins Sons and Company Limited, 1985.

Crambay. P and G. Briggs. Red Cross and St. John: The Official Record of the Humanitarian Services of the War Organization of the British Red Cross Society and Order of St. John of Jerusalem 1939-1947. London: Sunfield and Day, 1949.

Crang, Jeremy. The British Army and the People's War, 1939-1945. Manchester: Manchester University Press, 2000.

Crawly, Aidan. Escape from Germany: The Methods of Escape used by RAF Airmen during the Second World War. London: HMSO, 1985.

Dancocks, Daniel. In Enemy Hands: Canadian Prisoners of War, 1939-1945. Edmonton: Hurtig Publishers, 1983.

Dawson, Graham. Soldier Heroes: British Adventure, Empire and the Imagining of Masculinities. New York: Routledge, 1994.

Dear, Ian. Escape and Evasion: POW Breakouts in World War Two. London: Cassell, 2000.

Delanty, G. Community. London: Routledge, 2003.

Delve, Ken and Peter Jacobs. The Six-Year Offensive: Bomber Command in World War Two. Bath: The Bath Press, 1992.

Dunmore, Spencer. Above and Beyond: The Canadians' War in the Air, 1939-1945. Toronto: McClelland and Stewart Inc., 1996.

Dunmore, Spencer, and William Carter. Reap the Whirlwind: The Untold Story of 6 Group, Canada's Bomber Force of World War II. Toronto: McClelland \& Stewart Inc., 1991. 
Durflinger, Serge. Veterans with a Vision: Canada's War Blinded in Peace and War. Vancouver: UBC Press, 2010.

Dobson, Miriam and Benjamin Ziemann, eds. Reading Primary Sources: The Interpretation of Texts from 19th and 20th Century History. New York: Routledge, 2009.

English, Allan. The Cream of the Crop: Canadian Aircrew, 1939-1945. Montreal: McGillQueen's University Press, 1996.

Gamarnikow, Eva, David Morgan, June Purvis and Daphne Taylorson, eds. The Public and the Private. London: Heinemann Educational Books Ltd., 1983.

Garioch, Robert. Two Men and a Blanket: Memoirs of Captivity. Edinburgh: Southside, 1975.

Gayler, Robert. Private Prisoner: An astonishing story of survival under the Nazis. Wellingborough: New Edition Book Wove, 1984.

Gilbert, Adrian. POW: Allied Prisoners in Europe, 1939-1945. Great Britain: John Murray, 2006.

Gossage, Carolyn. Greatcoats and Glabour Boots: Canadian Women at War (1939-1945). Toronto: The Dundrun Group, 2001.

Granatstein, Jack and Desmond Morton. Canada and the Two World Wars. Toronto: Key Porter Books Limited, 2003.

Greenhous, Brereton, Stephen Harris and William Johnston. The Crucible of War, 1939-1945:

The Official History of the Royal Canadian Air Force, Volume III. Toronto: University of Toronto Press, 1994.

Gunn, Simon. History and Cultural Theory. Harlow, U.K: Pearson Education Limited, 2006.

Hamlin, John. Always Prepared: The Story of 207 Squadron Royal Air Force. London: Air Britain Historians Limited, 1999.

Harvey, Douglas. Boys, Bombs, and Brussels Sprouts. Toronto: McClelland \& Stewart Inc., 1981.

Hatch, F.J. The Aerodrome of Democracy: Canada and the British Commonwealth Air Training Plan, 1939-1945. Ottawa: Canadian Government Publishing Centre, 1983.

Hately-Broad, Barbara. War and Welfare: British POW families, 1939-1945. Manchester: Manchester University Press, 2009.

Hehner, Barbara. The Tunnel King: The Story of Whally Floody and the Great Escape. Toronto: Harper-Collins, 2004. 
Higate, Paul, ed. Military Masculinities: Identity and the State. London: Praeger, 2003.

Higonnet, Margaret, Jane Jenson, Sonya Michel, and Margaret Weitz, ed. Behind Enemy Lines: Gender and the Two World Wars. London: Yale University Press, 1987.

Hinton, James. Women, Social Leadership, and the Second World War: Continuities of Class. Oxford: Oxford University Press, 2002.

Holland, Robert, ed. Adversis Major: A Short History of the Educational Books Scheme. London: Staples Press/British Red Cross, 1949.

Holmes, Harry. Avro Lancaster: The Definitive Record. Shrewsbury: Airlife, 2001.

Hoven, Bettina, and Kathrin Horschelmannn. ed. Spaces of Masculinities. New York: Routledge, 2005.

Hutchinson, John. Champions of Charity: War and the Rise of the Red Cross. Colorado: Westview Press, Inc.,1996.

Johnson, Allan. The Blackwell Dictionary of Sociology: A User's Guide to Sociological Language. Malden, Mass: Blackwell Publishers, 2000.

Kee, Robert. A Crowd is not Company. London: Sphere, 1989.

Keshen, Jeffrey. Saints, Sinners, and Soldiers: Canada's Second World War. Vancouver: UBC Press, 2004.

Kelley, Ninette and Michael Trebilcock. The Making of the Mosaic: A History of Canadian Immigration. Toronto: University of Toronto Press Incorporated, 2010.

King, Stephen, ed. "Your Loving Son": Letters of an RCAF Navigator. Regina: Canadian Plains Research Center, 2002.

Kirby, Robert. Avro Manchester: The Legend Behind the Lancaster. Leicester: Midland Publishing Limited, 1995.

Kostenuk, Samuel and John Griffin. RCAF: Squadron Histories and Aircraft, 1924-1968. Toronto: Samuel Stevens Hakkert \& Company, 1977.

Lachmann, Richard, ed. The Encyclopedia Dictionary of Sociology. Guilford, Connecticut: Dushkin Publishers Group, 1991.

Lagrandeur, Philip. We Flew, We Fell, We Lived: The Remarkable Reminiscences of Second World War Evaders and Prisoners of War. London: Grub Street, 2007. 
Light, Beth and Ruth Pierson, ed. No Easy Road: Women in Canada 1920s to 1960s. Toronto: New Hogtown Press, 1990.

Mackenzie, S.P. The Colditz Myth: The Real Story of POW Life in Nazi Germany. Oxford: Oxford University Press, 2006.

Martin, Francis. The Flyer: British Culture and the Royal Air Force, 1939-1945. Oxford: Oxford University Press, 2008.

Marwick, Arthur. Total War and Social Change. Basingstoke: Macmillan, 1988.

Mason, Walter. Prisoners of War: Official History of New Zealand in the Second World War 1939-1945. Michigan: War History Branch, 1954.

McCaffery, Dan. Battlefields in the Air: Canadians in the Allied Bomber Command. Toronto: James Lorimer \& Company Ltd. Publishers, 1995.

McKibbin, M.N. Barbed Wire: Memoirs of Stalag 838. London: Staples Press, 1947.

Middlebrook, Martin and Chris Everitt. The Bomber Command War Diaries: An Operational Reference Book, 1939-1945. London: Midland Publishing Limited, 1996.

Millberry, Larry. Canada's Air Force: At War and Peace. Toronto: CANAV Books, 2000.

Millberry, Larry. Sixty Years: the RCAF and CF Air Command 1924-1984. Toronto: CANAV Books, 1984.

Milberry, Larry and Hugh Halliday. The Royal Canadian Air Force at War 1939-1945. Toronto: Canav Books, 1990.

Milner, Marc. Battled of the Atlantic. St. Catherines, Ontario: Vanwell Publication, 2003.

Moore, Bob and Kent Fedorowich, ed. Prisoners of War and their Captors in World War II. Washington, D.C.: Berg, 1996.

Morton, Desmond. A Military History of Canada. Toronto: McClelland \& Stewart Ltd., 2007

Morton, Desmond. Fight or Pay: Soldiers' Families in the Great War. Vancouver: UBC Press, 2004.

Neary, Peter and Jack Granatstein. The Veterans Charter and Post-World War II Canada. Montreal: McGill-Queen's University Press, 1997.

Nichol, John, and Tony Rennell. The Last Escape: The Untold Story of Allied Prisoners of War in Europe, 1944-45. London: Viking, 2002.

Nisbet, Robert. Sociology as an Art Form. New York: Oxford University Press, 1967. 
Page, Geoffrey. Shot Down in Flames: A World War Two Fighter Pilot's Remarkable Tale of Survival. London: Grub Street, 1999.

Pierson, Ruth. Canadian Women and the Second World War. Ottawa: Canadian Historical Association Historical Booklet, 1983.

Pierson, Ruth. "They're Still Women After All": The Second World War and Canadian Womanhood. Toronto: McClelland and Stewart, 1986.

Power, C. The R.C.A.F. Overseas: The First Four Years. Toronto: Oxford University Press, 1944.

Pryce, J. Heels in Hell. London: Minerva, 1998.

Reid, Pat. Escape from Colditz. New York: J.B. Lippincott Company, 1974.

Reid, Pat. Prisoner of War. New York: Beaufort Books Publishers, 1984.

Riley, Denise. War in the Nursery: Theories of the Child and Mother. London: Virago Press, 1983.

Robert, Leslie. There Shall Be Wings: A History of the Royal Canadian Air Force. Toronto: Clarke, Irwin \& Company Limited, 1959.

Rolf, David. Prisoners of the Reich: Germany's Captives, 1939-1945. London: Leo Cooper, 1988.

Rollings, Charles. Prisoner of War: Voices from Behind the Wire in the Second World War. London: Random House, 2008.

Romilly, Giles and Michael Alexander. The Privileged Nightmare. London: Pan Books Limited, 1955.

Rose, Jonathan. The Holocaust and the Book: Destruction and Preservation. Amherst: University of Massachusetts Press, 2001.

Rover, Constance. Women's Suffrage and Party Politics in Britain, 1866-1914. London: Routledge, 1967.

Royal Canadian Air Force. RCAF Logbook: A Chronological Outline of the Orgin, Growth and Achievement. Ottawa, King's Printer and Controlled of Stationery, 1949.

Royal Canadian Air Force. The R.C.A.F. Overseas: The First Four Years. Toronto: Oxford University Press, 1944. 
Scharff, Hanns and Raymond Toliver. The Interrogator: The Story of Hanns Scharff, Luftwaffe's Master Interrogator. Fallbrook, California: Aero Publishers, 1978.

Sheridan, Dorothy, ed. Wartime Women: An Anthology of Women's Wartime Writing for MassObservation, 1937-45. London: William Heinemann Ltd., 1990.

Shinn, Roger. War and Rumors of Wars. Nashville, Tenn: Abingdon Press, 1974.

Stacey, C.P., and Barbara Wilson. The Half-Million: The Canadians in Britain, 1939-1946. Toronto: University of Toronto Press, 1987.

Strachan, Tony, ed. In the Clutch of Circumstances: Reminiscences of Members of the Canadian National Prisoners of War Association. Victoria: Cappis Press, 1985.

Summerfield, Penny. Reconstructing Women's Wartime Lives: Discourse and Subjectivity in Oral Histories of the Second World War. Manchester: Manchester University Press, 1998.

Tansley, Donald. Final Report: An Agenda for Red Cross: Re-appraisal of the Role of the Red Cross. Geneva: Henry Dunant Institute, 1975.

Tuana, Nancy, William Cowling, Maurice Hamington, Greg Johnson and Terrance MacMullan. Revealing Male Bodies. Indianapolis: Indiana University Press, 1992.

Vance, Jonathan. A Gallant Company: The Men of the Great Escape. Pacifica, Cal.: Pacifica Press, 2001.

Vance, Jonathan ed. Encyclopedia of Prisoners of War and Internment. Santa Barbara: ABCCLIO, Inc., 2000.

Vance, Jonathan. High Flight: Aviation and the Canadian Imagination. London: Penguin Canada, 2002.

Vourkoutiotis, Vasilis. Prisoners of War and the German High Command: The British and American Experience. London: Palgrave Macmillan, 2003.

Vulliet, Andre. Preliminary Report of the War Prisoners Aid, Young Men's Christian Associations during World War II. Geneva, Switzerland: International Committee of the Young Men's Christian Associations, 1946.

Wakelam, Randall. The Science of Bombing: Operational Research in RAF Bomber Command. Toronto: University of Toronto Press, 2009.

Royal Canadian Air Force. RCAF Logbook: A Chronological outline of the Origin, Growth and Achievement of the Royal Canadian Air Force. Ottawa: King's Printer, 1949.

Waller, Jane and Michael Vaughan-Rees. Women in Uniform 1939-45. London: Papermac, 1989. 
Webster, Charles, and Frankland Noble. The Strategic Air Offensive Against Germany, 1939. 1945. London: Her Majesty's Stationery Office, 1961.

Wilson, Elizabeth. Women and the Welfare State. London: Tavistock Publications Limited, 1977.

Wylie, Ron. W., 400 (City of Toronto) Squadron History: 1932 to 1966. Toronto: 400 Squadron, 1996.

Yellin, Emily. Our Mothers' War: American Women at Home and at the Front During World War II. New York: Free Press, 2004.

Articles

Baumgartner, Joseph. "Newspapers as Historical Sources." Philippine Quarterly of Culture and Society 9 (1981): 256-258.

Barrett, Judy and David Smith. "US Women on the Home Front in World War II." Historian (December 1995): 349-360.

Beaumont, Joan. "Rank, Privilege and Prisoners of War." War and Society 1 (1983): 67-94.

Dreiford, John. "Anything but Ordinary: POW Sports in a Barbed Wire World." Journal of Sports History (Fall 2007): 415-437.

Hately-Broad, Barbara. "Nobody Would Tell You Anything": The War and Foreign Offices and British Prisoner of War Families during World War II." Journal of Family History 27 (2002): 459-477.

Knudson, Jerry. "Freedom of the Press in Latin America: Another View." Studies in Latin American Popular Culture, 2 (1983): 239-243.

Radford, R.A. "The Economic Organization of a P.O.W. Camp." Economica (November 1945): 189-201.

Rolf, David. "The Education of British Prisoners of War in German Captivity, 1939-1945." History of Education 18 (1989): 257-265.

Rollings, Charles. “Dulag Luft.” After the Battle 106 (1999): 1-27

Samuel, R. "North and South: a Year in a Mining Village." London Review of Books 17 no.12 (1995): 3-6. 
Shavit, David. "The Greatest Morale Factor next to the Red Army": Books and Libraries in American and British Prisoner of War Camps in Germany During World War II." Libraries and Culture 34, No. 2 (Spring 1999): 112-122.

Tisdall, Frederick. "Final Report on the Canadian Red Cross Food Parcels for Prisoners-of-War." The Canadian Medical Association Journal (March 1949): 280-284.

Tisdall, Frederick. "Further Report on the Canadian Red Cross Food Parcels for Prisoners-ofWar." The Canadian Medical Association Journal (March 1949): 135-138. Vance, Jonathan. “Canadian Relief Agencies and Prisoners of War, 1939-1945.” Journal of Canadian Studies 31 (1996): 133-147.

Vance, Jonathan. "The Politics of Camp Life: The Bargaining Process in Two German Prison Camps." War \& Society, 10 (1992): 109-126.

Vourkoutiotis, Vasilis. "What the Angels Saw: Red Cross and Protecting Power Visits to AngloAmerican POWs, 1939-45." Journal of Contemporary History 40 (2005): 690-708.

\section{Tertiary Sources}

Website

Blackwell Encyclopedia of Sociology. "Sociology." Accessed 16 July 2012. http:// www.sociologyencyclopedia.com/public/.

Canadian Red Cross. "Canadian Red Cross - Centennial Celebration." Accessed 4 June 2012. www.redcross.ca/centennialtimeline/1940.html.

Canadian Red Cross. "Responding to the Call of Duty during WWII." Accessed 5 June 2012. www.redcross.ca/print.asp?id=013222.

Canadian War Graves Commission. "Search for War Dead: George McLaughlin. Accessed 16 July 2012. http://www.cwgc.org/find-war-dead/casualty/2048037/McLAUGHLIN, \%20GEORGE\%20LLOYD

Canadian War Graves Commission. "Search for War Dead: Harvey Lacelle. Accessed 16 July 2012. http://www.cwgc.org/search-for-war-dead/casualty/2033962/LACELLE, \%20JOSEPH\%20HARVEY\%20MILTON.

Canadian War Graves Commission. "Search for War Dead: John Allan Maville." Accessed 16 July 2012. http://www.cwgc.org/search-for-war-dead/casualty/2358645/MAVILLE, \%20JOHN\%20ALLAN. 
Canadian War Graves Commission. "Search for War Dead: Jules Robert Rene Villeneuve. Accessed 16 July 2012. http://www.cwgc.org/search-for-war-dead/casualty/1526496/ VILLENEUVE,\%20JULES\%20ROBERT\%20RENE.

Canadian War Graves Commission. "Search for War Dead: Laurie Alban Bourgeois. Accessed 16 July 2012. http://www.cwgc.org/search-for-war-dead/casualty/1530150/BOURGEOIS, \%20LAURIE\%20ALBAN.

Canadian War Graves Commission. "Search for War Dead: Stanleigh Lowry Reid. Accessed 16 July 2012. http://www.cwgc.org/search-for-war-dead/casualty/2041385/REID, \%20STANLEIGH\%20LOWRY.

County of Renfrew. "Pretty as a Picture." Accessed 16 July 2012. http:// www.countyofrenfrew.on.ca/.

"Eat, Drink, Smoke and be Creative." Accessed 12 July 2012. http://phillipsamoore.com/ edmoore/newmoorepage13.html.

Gary Moncor. "Dulag Luft." Accessed 12 July 2012. http://www.303rdbg.com/pow-camps.html.

Hal Stoen. "The Long Voyage of the Ship Pasteur." Accessed 13 March 2012. http:// stoenworks.com/louis\%20pasteur.html.

Hillary Evans. “Harvey Lacelle.” Accessed 3 July 2012. http://www.sports-reference.com/ olympics/athletes/la/herve-lacelles-1.html.

International Committee of the Red Cross. "1939 to 1945: Descent into Hell." Accessed 4 June 2012. http://www.icrc.org/eng/who-we-are/history/second-world-war/overview-2-worldwar.htm.

International Committee of the Red Cross. "International Humanitarian Law - Treaties \& Documents. Accessed 14 July 2012. http://www.icrc.org/ihl.nsf/full/305?opendocument.

Metroland Media. "Renfrew Mercury." Accessed 29 July 2012. http://www.metroland.com/ communities/100092/renfrew_mercury.

Military Intelligence Service War Department (1945). "Dulag Luft." Accessed 8 July 2012. http://www.b24.net/pow/dulag.htm.

Ontario Power Authority. “Renfrew Upper Plant Generating Station.” Accessed 21 July 2012. http://www.powerauthority.on.ca/hydroelectric/renfrew-upper-plant-generating- station099-mw-renfrew-bonnechere-river.

Oxford English Dictionary. "Pharnygo." Accessed 2 December 2012. http:// www.oed.com.proxy.library.carleton.ca/view/Entry/142260redirected From=Pharyngo\#eid. 
Robert Brown. "No 112 Squadron." Accessed 29 July 2012. http://www.rafweb.org/ Sqn111-115.htm.

Royal Canadian Air Force. "400 Tactical Helicopter Squadron.” Accessed 20 July 2012. http:// www.rcaf-arc.forces.gc.ca/v2/hst/page-eng.asp?id=694.

Royal Air Force. "RAF Cranwell.” Accessed 28 July 2012. http://www.raf.mod.uk/rafcranwell/.

Royal Air Force. "225 Squadron.” Accessed 29 July 2012. http://www.raf.mod.uk/history/ 225 squadron.cfm.

Royal Air Force. "History of RAF Odiham. Accessed 29 July 2012. http://www.raf.mod.uk/ rafodiham/aboutus/history.cfm.

Royal Air Force. "Bomber Command No. 207 Squadron. Accessed 29 July 2012. http:// www.raf.mod.uk/history/bombercommandno207squadron.cfm.

Robert Kirby. "New Information on the Loss of Manchester EM-W L730." Accessed 29 July 2012. http://www.207squadron.rafinfo.org.uk/manchesters/ manchesters_L7380ameland.htm.

Sheila Bryne. "Note on Crewing Up." Accessed 18 July 2012. http://www.214squadron.org.uk/ Crews_and_losses.htm.

Wilkie Wanless. “Learning by Experience.” Accessed 7 July 2012. www.rafbombercommand.com/personals_2_dangersofwar.html.

World Atlas Book. "Map of Germany with Cities and States." Accessed 24 July 2012. http:// www.worldatlasbook.com/germany/germany-political-map.html.

Yatesbury Association. "RAF Yatesbury Association. Accessed 28 July 2012. http:// www.rafyatesbury.webs.com. 